\title{
Identification of Contaminants of Concern
}

\author{
Columbia River Comprehensive Impact Assessment
}

\author{
B. A. Napier \\ N. C. Batishko \\ D. A. Heise-Craff \\ M. F. Jarvis \\ S. F. Snyder
}

January 1995

Prepared for the U.S. Department of Energy

under Contract DE-AC06-76RLO 1830

Pacific Northwest Laboratory

Richland, Washington 99352

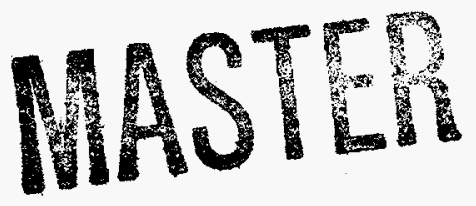




\title{
DISCLAIMER
}

This report was prepared as an account of work sponsored by an agency of the United States Government. Neither the United States Government nor any agency thereof, nor Battelle Memorial Institute, nor any of their employees, makes any warranty, expressed or implied, or assumes any legal liability or responsibility for the accuracy, completeness, or usefulness of any information, apparatus, product, or process disclosed, or represents that its use would not infringe privately owned rights. Reference herein to any specific commercial product, process, or service by trade name, trademark, manufacturer, or otherwise does not necessarily constitute or imply its endorsement, recommendation, or favoring by the United States Government or any agency thereof, or Battelle Memorial Institute. The views and opinions of authors expressed herein do not necessarily state or reflect those of the United States Government or any agency thereof.

\author{
PACIFIC NORTHWEST LABORATORY \\ operated by \\ BATTELLE MEMORIAL INSTITUTE \\ for the \\ UNITED STATES DEPARTMENT OF ENERGY \\ under Contract DE-ACO6-76RLO 1830
}

Printed in the United States of America

Available to DOE and DOE contractors from the

Office of Scientific and Technical Information, P.O. Box 62, Oak Ridge, TN 37831; prices available from (615) 576-8401. FTS 626-8401.

Available to the public from the National Technical Information Service, U.S. Department of Commerce, 5285 Port Royal Rd., Springfield, VA 22161. 


\section{DISCLAIMER}

Portions of this document may be illegible in electronic image products. Images are produced from the best available original document. 


\title{
Department of Energy
}

\author{
Richland Operations Office \\ P.O. Box 550 \\ Richland, Washington 99352 \\ FEB - 61995
}

Those on Attached List:

\section{SOLICITATION OF COMMENTS ON DRAFT IDENTIFICATION OF CONTAMINANTS OF CONCERN REPORT}

The U.S. Department of Energy, Richland Operations Office (RL), has negotiated an agreement with the State of Washington Department of Ecology (Ecology) and the U.S. Environmental Protection Agency (EPA) to perform a comprehensive impact assessment of current and residual Hanford-derived contaminants to the Columbia River for remedial decisions at the Hanford Site. Associated current human health and environmental impacts will be assessed. This process will utilize an ecosystem approach for guiding remedial decisions. 100-Area, 200Area, and 300-Area operable units will continue to assess contaminant sources and remediation. The Columbia River Comprehensive Impact Assessment (CRCIA) will address a11 Columbia River contaminants, risk assessments, and remediation. If unacceptable levels of human health or environmental risk are found, appropriate remedial actions will be initiated consistent with the National Contingency Plan and the Hanford Federal Facility Agreement and Consent Order (Tri-Party Agreement) through the Hanford Past Practice Strategy. Remedial decisions resulting from the CRCIA will consider impacts to the environment and natural resources from alternative remedial options as part of the remedial decision process.

The initial CRCIA effort was the development of a "compendium" of existing data on Columbia River contamination (a bibliography of data sources has been developed in support of this effort).

The next step is to define the "contaminants of concern" for this study. A contaminants of concern report has been produced which documents an initial review, from a risk perspective, of historical data concerning current or potential contamination in the Columbia River. Sampling data were examined for over 600 chemical and radioactive contaminants. A screening analys is was performed to identify those substances present in such quantities that they may pose a meaningful human or ecological risk. The substances identified will require a more detailed analysis to assess their impact on humans or the river ecosystem.

The next document to be produced will be an identification of the "species of concern" for this study. It is the intention of RL and PNL to solicit early input, from those interested, concurrently with the review and comment period of the enclosed document. 
$\mathrm{RL}$ is pleased to provide you a copy of the draft subject document for your review. This document has not undergone review by $\mathrm{RL}$, or the regulatory agencies (Ecology and EPA); therefore, there is ample opportunity to provide meaningful input prior to its finalization. Please provide comments to Mr. Randy Brich at this address by March 10, 1995. Mr. Brich may be reached at (509) 376-9031. RL and its contractor for this study, Pacific Northwest Laboratory (PNL), are pleased to meet with those interested; please let $\mathrm{Mr}$. Brich know if you desire to do so.

RSD:RFB

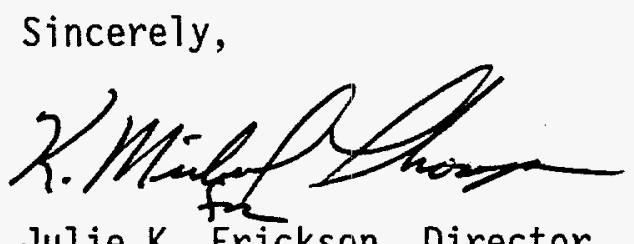

Julie K. Erickson, Director

Enclosure

CC W/encl:

R. F. Stanley, Ecology 
No. of

Copies

Offsite

12 DOE Office of Scientific and Technical Information

M. Bauer

Confederated Tribes and Bands of the Yakama Indian Nations

P.O. Box 151

Toppenish, WA 98948

S. Benz

600 S. Kent \#71

Kennewick, WA 99336

L. Block

U.S. Fish and Wildlife Service

Moses Lake Field Office

P.O. Box 1157

Moses Lake, WA 98837

D. Bradshaw

Audobon Society of Portland

5151 Northwest Cornell Road

Portland, OR 97210

N. Buske

Search Technical Services

Star Route Box 17

Davenport, WA 99112

D. Cellarius

Sierra Club Northwest Office

1516 Melrose Avenue

Seattle, WA 98122

C. Cline

State of Washington

Department of Ecology

P.O. Box 47600

Olympia, WA $98504-7600$
No. of

Copies

F. R. Cook

2552 Harris

Richland, WA 99352

J. P. Corley

2213 Torbett

Richland, WA 99352

2 DNR Hanford Projects

Attn: J. R. Wilkinson

Confederated Tribes of the Umatilla Indian Nation

P.O. Box 638

Pendleton, OR 97801

G. deBruler

Columbia River United

P.O. Box 667

Bingen, WA 98605

C. Denniston

Greenpeace

11815 - 20th SW

Seattle, WA 98146

B. Drost

USGS Water Resources Division

Washington District

1201 Pacific Avenue Suite 600

Tacoma, WA 98402

D. Dunning

Oregon Dept. of Energy

625 Marion Street NE

Salem, OR 97310

3 J. Erickson

Division of Radiation Protection

Washington State Dept. of Health P.O. Box 47827

Olympia, WA 98504-7827 
M. Fox, President

Hanford Family

P.O. Box 1462

Richland, WA 99352

R. Gardiner

614 Sherman Drive

The Dalles, OR 97058

N. J. Germond

League of Women Voters

224 Iron Mountain Boulevard

Lake Oswego, OR 97034

D. Maez

4214 W. John Day Place

Kennewick, WA 99336

C. Mebane

National Oceanic and Atmospheric Administration

c/o EPA Seattle Office

1200 6th Avenue, HW-113

Seattle, WA 98101

J. Monteith

Oregon Natural Resources Council

1161 Lincoln Street

Eugene, OR 97401

D. Nichols

WNP-1

Building 52

Richland, WA 99352

R. Patt

Water Resources Department 158 - 12th Street N.E.

Salem, OR 97310-0210

G. Pollet

Heart of America Northwest

1305 4th Avenue, 208

Seattle, WA 98101
2 D. Powaukee

Nez Perce Tribe

P.O. Box 365

Lapwai, ID 83540

S. M. Alexander

State of Washington

Department of Ecology

1315 W. Fourth Avenue

Kennewick, WA 99336-6018

L. Stembridge

HEAL

1408 West Broadway Avenue

Spokane, WA 99201-1902

C. Stephan

1520 Torthay Court

Richland, WA 99352

3 D. Stewart-Smith

Oregon Department of Energy

625 Marion Street NE

Salem, OR 97310

J. P. Thomas

HHIN Resource Center

1719 Smith Tower

506 Second Avenue

Seattle, WA 98104

Onsite

5 State of Washington

Department of Ecology

D. P. Holland (4)

J. W. Yokel

B5-18

B5-18

$5 \quad$ U.S. Department of Energy

Richland Operations Office

DOE Public Reading Room 
No. of

Copies

4 Westinghouse Hanford Company

Administrative Record (3)

H6-08

A. S. Carlson

B3-35

6 U.S. Environmental Protection Agency
L. E. Gadbois (5)
B5-01
D. R. Sherwood
B5-01

$37 \quad$ Pacific Northwest Laboratory

N. C. Batishko

S. D. Cannon

R. L. Dirkes

P. W. Eslinger

S. L. Friant

M. S. Hanson
No. of

Copies

G. L. Harvey

K2-02

P. C. Hays

$\mathrm{K} 9-41$

D. A. Heise-Craff

K3-54

L. R. Huesties

K6-61

M. F. Jarvis

K6-55

A. D. Maughan

K6-52

T. B. Miley

K5-12
K3-54

L. F. Morasch

B. A. Napier (5)

D. B. Shipler

S. F. Snyder

W. L. Templeton

W. H. Walters

L. K. Wenrich (5)

B. K. Wise

Records Center (2)

Publishing Coordination

Technical Library (5)

K6-62

K3-54

K9-13

K3-54

K9-13

K9-33

K3-70

K9-04

K3-70

K1-06

$\mathrm{K} 9-13$

K6-52

K9-02 

The environmental quality of the Columbia River is of special interest to the public, government, and tribal governments as a source of drinking water, for crop irrigation, as ecological habitat, and for recreation. The following actions have been taken to encourage public invollvement in the CRCIA Project:

- PNL has an open door policy for this project. Non-PNL individuals can visit the laboratory, interact with scientists, and observe work in progress.

- Data and documents used in the CRCIA Project are being made available to all interested parties.

- Public meetings are being conducted to obtain input to the development of work scope and technical approaches as well as to review data and work progress. 


\begin{abstract}
The Columbia River Comprehensive Impact Assessment (CRCIA) Project is conducted for the U.S. Department of Energy by the Pacific Northwest Laboratory. The CRCIA Project will evaluate the current human and ecological risks from the Columbia River attributable to past and present activities on the Hanford Site. To perform a comprehensive assessment, the contaminants released from the Hanford Site must be identified. This report identifies the contaminants released and identifies those that should be considered in detailed risk analyses.
\end{abstract}





\section{Summary}

\section{Introduction}

The Columbia River Comprehensive Impact Assessment (CRCIA) Project is conducted for the U.S. Department of Energy by the Pacific Northwest Laboratory (PNL). The CRCIA Project will evaluate the current human and ecological risks from the Columbia River attributable to past and present activities on the Hanford Site. To perform a comprehensive assessment, the contaminants released from the Hanford Site must be identified. This report identifies the contaminants released and identifies those that will be considered in detailed risk analyses.

\section{Scope of Work}

The CRCIA Project is primarily concerned with the current risks from contaminants of Hanford origin. Therefore, the most recent sampling data (from 1980 through 1994) were used to estimate the source term (amount and types of radionuclides and chemicals released to the environment from Hanford facilities) for the risk calculations. For this study, the focus is on the Columbia River water, sediment, soil, and groundwater within 150 meters ( 500 feet) of the Columbia River, which means a spatial focus on the Hanford 100, 300, and 1100 Areas. A multi-stage screening process was developed to prioritize these various contaminants in terms of human health risk and ecosystem risk. Each stage of the process identifies contaminants of interest to the project, based on the potential for human and ecological risk. The combined results of the total screening then compose the total list of concern.

In addition to radiological and chemical contaminants, the potential for radiation doses arising from discrete radioactive particles in the river sediment or from direct irradiation from near-river Hanford facilities is also addressed.

Although the primary concern is the current status of the Columbia River, additional consideration is given to the potential impact of contaminants currently known to be in the Hanford Site groundwater. Consideration is not given to the potential impact of contaminants that are not presently in the groundwater but which may be in soils or facilities away from the Columbia River.

\section{Technical Approach}

The first step. in the approach was to collect a comprehensive list of potential contaminants. This list was prepared by examining published data, reports, and contaminant databases. The review of the available data indicated that concentrations of various radionuclides, carcinogenic chemicals, and hazardous chemicals had been measured in surface water (Columbia River, springs, and seeps), groundwater, river sediment, and near-river soil. A multi-stage screening process was developed to prioritize these various contaminants in terms of human health risk and ecosystem risk. Each stage of the process identifies contaminants of interest. The combined results of the entire screening process then compose the total list of contaminants of concern. The following screening processes were used. 
Initial Screening: Initial screening eliminated the contaminants on the list that showed no detectable levels of activity or concentration.

Radionuclide Screening: Radionuclide screening is based on a scenario of exposure to an individual. The exposure includes external exposure, consumption of untreated river water, consumption of freshwater fish, and consumption of small amounts of sediment. Internal risks are estimated using the U.S. Environmental Protection Agency (EPA) indicator for ingestion, called a slope factor (EPA 1994a). This indicator represents the risk of cancer to an individual from sources other than natural background radiation per unit (e.g., picocurie) of radioactive material taken into the body. Similarly, external exposure to contaminated sediment is addressed by assuming the parameters associated with the EPA slope factor for external exposure are appropriate (EPA 1994a).

Carcinogenic Chemical Screening: The individual exposure scenario for carcinogens in river water are the same as those for radionuclides, except there is no factor for external exposure because there is no external risk from chemicals.

Toxic Chemical Screening: For hazardous, but noncarcinogenic, chemicals, the screening is based on a ratio of the estimated daily intake to the EPA chronic oral reference dose (EPA 1994a). The chronic oral reference dose is the safe dose level EPA established for specific chemicals. In other words, the chemicals in the individual exposure scenario are investigated to screen out those that are ingested in amounts below the EPA's safe levels. The exposure scenario is the same as for the radionuclides or carcinogens.

Ambient Water Quality Criteria Screening: For aquatic plants and animals (biota), the measured or surrogate (estimated) concentration of the contaminant in water is compared with the applicable EPA water quality criterion (EPA 1992). The ambient water quality criteria are those concentrations of chemicals identified by EPA as safe and protective of aquatic life.

Aquatic Biota Toxicity Screening: Limited data were available that identify the concentrations of certain chemicals that result in toxic effects to aquatic life. Where possible, the threshold concentration for fresh water at which any effect was noted was used. Where not possible, the lowest concentration lethal to 50 percent (called LC50) of small, freshwater fish (e.g., guppies, mosquito fish, rainbow trout) was used (EPA 1985). To relate these lethal effects to less significant effects, the screening used a value of 1 percent of the LC50. For a few analytes (substances for which an analysis is made) for which fish data were not available, test results for crayfish or insects were used as a surrogate.

Background Screening: During the screening process, a few radionuclides and chemicals had measurements determined to be within their respective naturally occurring background levels. Because concentrations were not above naturally occurring background, the following contaminants were eliminated from further consideration: the radionuclides beryllium-7 and potassium- 40 ; the chemicals barium, bismuth, boron, chlorine, fluorine, lithium, silicon, silver, sulfide, titanium, vanadium, and zirconium.

Nonhazardous Screening: The screening process identified several materials as nonhazardous under environmental conditions (EPA 1991; EPA 1989). These contaminants eliminated from further consideration are aluminum, calcium, iron, magnesium, potassium, and sodium. 
All of the screenings require an estimate of the contaminant's concentration in river water. Only the direct river water measurements provide this information. When direct measurements of river water were not available, surrogate water concentration was estimated. To estimate surrogate concentrations in water, certain assumptions were used.

Groundwater Contamination: Groundwater adjacent to the Columbia River can flow into the river, and Columbia River water can flow into the groundwater, depending on river flow. Therefore, concentrations of contaminants in groundwater near the river are difficult to predict, and concentrations measured near the shore differ from those measured further inland. Raymond et al. (1976) and Cline et al. (1985) report an estimated flow rate of 100 cubic feet per second (cfs) over the entire Hanford Reach. For conservatism (i.e., to provide an estimate of the resulting concentration in the river that, if incorrect, would err on the high side), the value of $100 \mathrm{cfs}$ was adopted for the screening. In effect, this implies that the entire groundwater that flows from beneath Hanford to the Columbia River is contaminated to the maximum level measured.

River Sediment: Sediment within the river is both a reservoir of contaminants and a source of contamination of the river water, as the material is dissolved into or carried away by the river. An equilibrium ratio of 1:100,000 was used (i.e., the concentration of the contaminant in the sediment is assumed to be 100,000 times higher than in the Columbia River waters). This assumption is based on a limited number of samples and an empirical equation (Napier et al. 1988, p. 4.82).

Near-River Soil: Contaminants in Hanford waste sites or other sites adjacent to the Columbia River (e.g., operating facilities, spills, etc.) may pose a threat of future contamination of the river. For the purpose of screening, all contaminants are assumed to be environmentally mobile and potentially dissolvable in groundwater. Based on this assumption, the surrogate groundwater contamination is assumed to have the same concentration of contaminants as the soil. The total area of industrial activity comprises approximately 6 percent of the Hanford Site (Dirkes et al. 1994, p. 5). Because it is unreasonable to assume that all of Hanford soil is contaminated to the maximum concentration measured, an effective area of 1 percent is assumed. This means that the study assumed that 1 percent of Hanford soil is contaminated to the same extent as the highest amounts measured in Hanford soil.

\section{Results}

Analyses for more than 600 different radionuclides and chemicals have been performed on Hanford-related environmental samples. A large number of these potential contaminants have never been detected in the Hanford/Columbia River environments. Screening on the basis of potential impact on human health or the health of Columbia River ecosystems has been performed for the roughly 100 radionuclides and chemicals that have been detected in environmental samples. Several different types of screenings were employed. The results were consistent in that the same materials were identified numerous times by the various screenings. Application of the screenings for contaminants within 150 meters (500 feet) of the Columbia River yields a list of 20 contaminants of concern, plus direct irradiation. These contaminants are given in the first column of Table S.1. 
Table S.1. List of Identified Contaminants of Concern ${ }^{(a)}$

\begin{tabular}{|c|c|c|}
\hline $\begin{array}{l}\text { In Columbia River, Ground- } \\
\text { water, }{ }^{(b)} \text { Sediment, and Soil }\end{array}$ & $\begin{array}{l}\text { Groundwater Plumes Away } \\
\text { from the Columbia River }{ }^{(\mathrm{c})}\end{array}$ & $\begin{array}{l}\text { Continued Public } \\
\text { Interest }\end{array}$ \\
\hline $\begin{array}{l}\text { Antimony } \\
\text { Arochlor } 1248 \text { (PCB) } \\
\text { Arsenic } \\
\text { Cesium-134 } \\
\text { Cesium-137 } \\
\text { Chlordane } \\
\text { Chromium }^{(\mathrm{d})} \\
\text { Cobalt-60/particles } \\
\text { Copper } \\
\text { Diesel Fuel } \\
\text { Europium-152 } \\
\text { Europium-154 } \\
\text { Lead } \\
\text { Manganese } \\
\text { Mercury } \\
\text { Nitrate/nitrite } \\
\text { Phosphate } \\
\text { Silver Chloride } \\
\text { Strontium-90 } \\
\text { Zinc }\end{array}$ & $\begin{array}{l}\text { Carbon Tetrachloride } \\
\text { Fluoride }\end{array}$ & $\begin{array}{l}\text { Chloroform } \\
\text { Cyanide } \\
\text { Iodine-129 } \\
\text { Plutonium-239/240 } \\
\text { Technetium-99 } \\
\text { Trichloroethylene } \\
\text { Tritium (Hydrogen-3) } \\
\text { Uranium }\end{array}$ \\
\hline $\begin{array}{l}\text { (a) Direct irradiation is also identified as ber ber } \\
\text { (b) Hanford groundwater within } 150 \text { meter } \\
\text { (c) Hanford groundwater farther than } 150 \\
\text { (d) These conaminants are also of concern } \\
\text { list to avoid duplication. }\end{array}$ & $\begin{array}{l}\text { of the Columbia River. } \\
\text { feet) from the Columbia River. } \\
\text { water plumes away from the Colun }\end{array}$ & ver but are not repeated in that \\
\hline
\end{tabular}


Existing Hanford groundwater contamination farther than 150 meters (500 feet) (see Table 3.3) from the Columbia River was also addressed. The contaminants identified by the screening process do not appear to be currently entering the river but have the potential to do so within 10 to 200 years (Freshley and Graham 1988). Two contaminants (chromium and nitrate) in Hanford groundwater away from the river are already included in this study because they are in or near the river. Only carbon tetrachloride and fluoride were added to the list as a result of the study of groundwater away from the river. Carbon tetrachloride and fluoride have not yet been found in the river.

Although the screenings did not indicate a potential risk, several potential or existing contaminants are of particularly high public interest (third column in Table S.1). Essentially all of these are the object of ongoing evaluation by the Surface Environmental Surveillance Project (SESP) conducted by PNL at Hanford. The CRCIA Project should remain current on SESP activities and include SESP results in all project reports (see Section 8.0).

Each of the identified contaminants can be considered to have resulted from past plutoniumproduction operations at Hanford. The radionuclides on the list generally represent those identified with river water or Hanford Reach sediment. The radionuclides resulted from activation of materials in the old production reactors. It is likely that the cesium isotopes are related to global fallout (Dirkes et al. 1994). Most of the metals identified from Hanford groundwater or sediment can be related to various Hanford operations in the 100 Areas. The polychlorinated biphenyl (PCB), Arochlor 1248, is used in equipment and the insecticide, Chlordane, has been used at Hanford facilities, but both are still essentially associated with soil near the river. The nitrate groundwater plumes result from past Hanford operations in the 100 and 200 Areas.

The identification of the radionuclides and chemicals as being of concern to the CRCIA Project does not imply that each or all of these compounds is necessarily a prominent problem for the river or those who live downstream. The screening and selection process described in this report is a conservative (cautious) process designed to focus the resources of the project on those contaminants with potential risk. 



\section{Glossary}

100 Areas - site of the Hanford production reactors, which include B, C, D, DR, F, H, KE, KW, and $\mathrm{N}$ reactors.

200 Areas - site of the Hanford chemical separations plants, which include the bismuth phosphate process plants (B and T Plants), plutonium uranium extraction plant (A Plant/PUREX), and reduction and oxidation plant (S Plant/REDOX).

300 Area - site of research, development, and fuel-fabrication operations.

400 Area - site of the Fast Flux Test Facility.

600 Area - all land within the Hanford Site not occupied by the $100,200,300,400,1100$, or 3000 Areas.

1100 Area - site of the warehousing, vehicle maintenance, and transportation operations center.

3000 Area - site of engineering, construction, and research and development activities.

analytes - substances for which an analysis is made.

bioconcentration factor - ratio between the radionuclide concentration in biota and the radionuclide concentration in the water in which the biota live and feed.

biota - plants and animals.

carcinogenic (chemicals) - having the property of enhancing the possibility of contracting cancer later in life following exposure.

CERCLA - Comprehensive Environmental Response, Compensation, and Liability Act of 1980.

Ci - abbreviation for curie.

concentration - amount of a specified substance (e.g., a radioactive element) in a unit amount of another substance (e.g., river water, milk).

conceptual model - any representation of a biological or mechanical process.

CRCIA - Columbia River Comprehensive Impact Assessment.

curie - unit of radioactivity corresponding to $3.7 \times 10^{10}$ (37 billion) disintegrations per second (abbreviated $\mathrm{Ci}$ ), 1 curie $=3.7 \times 10^{10}$ becquerel.

DOE - U.S. Department of Energy. 
Ecology - Washington State Department of Ecology.

EIS - environmental impact statement.

EPA - U.S. Environmental Protection Agency.

exposure - process of coming into contact with environmental materials.

internal exposure - contact with materials taken into the body through inhalation or ingestion.

external exposure - contact with materials on the outside of the body, as from submersion in water or immersion in air.

gross beta - total activity of beta-emitting radionuclides that are not distinguished separately by instrumentation or radiochemical analyses.

half-life - time required for an initial number of radioactive atoms to be reduced to half that number by radiological transformations.

Hanford Reach - stretch of the Columbia River downstream of Priest Rapids Dam and upstream of the confluence of the Yakima and Columbia Rivers.

hazardous (chemicals) - having the property of being toxic, at some level of exposure. Generally used to differentiate from carcinogenic.

HEIS - Hanford Environmental Information System. An electronic database that consolidates the data gathered during environmental monitoring and restoration of the Hanford Site.

HWMA - Washington State Hazardous Waste Management Act of 1976.

IRIS - Integrated Risk Information System, an EPA database that provides data on chronic health hazards (reference dose values), carcinogenicity (unit risk factors or slope factors), EPA regulatory actions, supplementary data, and a bibliography for each listed chemical.

irradiation - exposure of an object to ionizing radiation.

isotope - one of two or more atoms having the same atomic number but different mass.

LFI - limited field investigation conducted as part of Tri-Party Agreement activities to identify those Hanford waste sites that are recommended to remain as candidates for interim remedial measures.

MEPAS - Multimedia Environmental Pollutant Assessment System, a computer code that can be used to estimate the transport and fate of environmental pollutants. 
model - conceptual representation of a physical/biological process. The representation may be graphical or a set of mathematical equations that simulate the process being modeled. See also conceptual model.

natural uranium - naturally occurring mixture of uranium (0.7 percent uranium-235 and 99.3 percent uranium-238).

NPL - national priorities list.

operable unit - term used to identify specific areas designated for cleanup.

PCB - polychlorinated biphenyl.

picocurie - one-millionth of a millionth curie $\left(10^{-12}\right)$.

plume - definitive volume of air, water, or soil containing contaminants released from a contaminant source.

PNL - Pacific Northwest Laboratory.

production reactor - facility $(\mathrm{B}, \mathrm{C}, \mathrm{D}, \mathrm{DR}, \mathrm{F}, \mathrm{H}, \mathrm{KE}, \mathrm{KW}$, or $\mathrm{N}$ reactors) in which uranium or other fuel was irradiated with neutrons to produce radioactive materials. Used primarily at Hanford to produce plutonium for weapons; used also for research. Synonymous with "reactor."

radioactivity - spontaneous emission of radiation (alpha, beta, gamma rays, and/or neutrons) by some isotopes as they transform into other isotopes.

radionuclide - radioactive isotope of an element.

RCRA - Resource Conservation and Recovery Act of 1976.

reactor - see production reactor.

reference dose - EPA's estimate of the smallest daily intake of a hazardous material that first leads to deleterious health effects.

RI/FS - remedial investigation/feasibility study.

SARA - Superfund Amendments and Reauthorization Act.

seeps - very small springs of groundwater.

SESP - Surface Environmental Surveillance Project.

slope factor - EPA's value which represents the lifetime excess cancer risk per unit of intake. 
source term - amount of radioactivity (curies) of a radionuclide or amount of a chemical released to the environment from a facility over a given time.

springs - source of water issuing from the ground.

SST - single-shell tank.

stack - tall chimney that was the primary release point of exhaust air from a reactor or separations plant building.

surrogate (measurement) - estimated substitute measurement used when actual measurements not available.

TPA - Tri-Party Agreement (officially, Hanford Federal Facility Agreement and Consent Order).

TSD - treatment, storage, and disposal facilities or units at Hanford.

TWRS - tank waste remediation system.

UST - underground storage tank.

VOC - volatile organic compounds. 


\section{Contents}

Preface $\ldots \ldots \ldots \ldots \ldots \ldots \ldots \ldots \ldots \ldots \ldots \ldots \ldots \ldots \ldots \ldots \ldots \ldots \ldots$

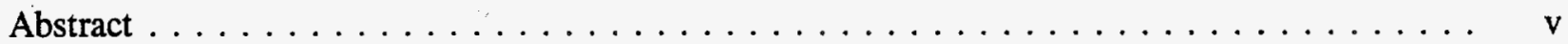

Summary $\ldots \ldots \ldots \ldots \ldots \ldots \ldots \ldots \ldots \ldots \ldots \ldots \ldots \ldots \ldots \ldots \ldots \ldots \ldots \ldots$

Glossary $\ldots \ldots \ldots \ldots \ldots \ldots \ldots \ldots \ldots \ldots \ldots \ldots \ldots \ldots \ldots \ldots \ldots \ldots \ldots$

1.0 Introduction $\ldots \ldots \ldots \ldots \ldots \ldots \ldots \ldots \ldots \ldots \ldots \ldots \ldots \ldots \ldots \ldots \ldots \ldots$

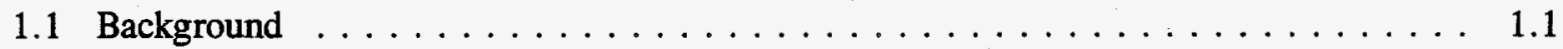

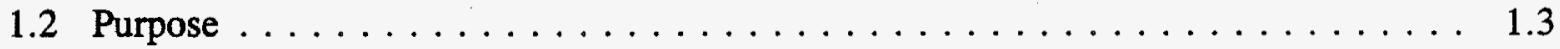

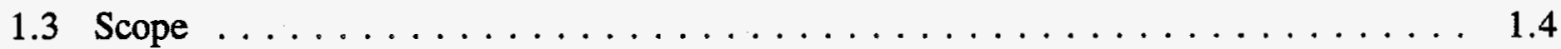

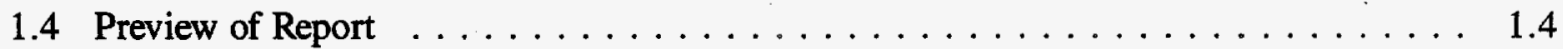

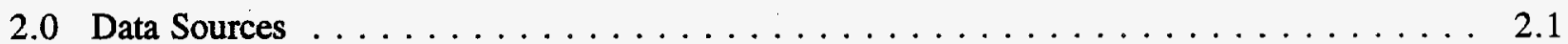

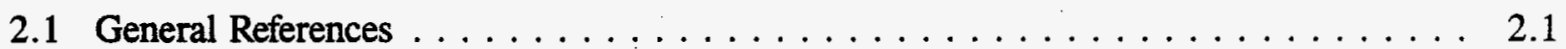

2.2 Hanford Environmental Information System $\ldots \ldots \ldots \ldots \ldots \ldots$

2.3 Remedial Investigation $/$ Feasibility Studies $\ldots \ldots \ldots \ldots \ldots$

2.4 Hanford Site Environmental Reports $\ldots \ldots \ldots \ldots \ldots \ldots \ldots \ldots \ldots$

2.5 Limited Field Investigations $\ldots \ldots \ldots \ldots \ldots \ldots \ldots \ldots \ldots \ldots \ldots \ldots \ldots$

2.6 Discrete Radioactive Particles and Other Direct Exposure Sources . . . . . . . . . . . 2.9

2.7 National Environmental Policy Act (NEPA) Documents $\ldots \ldots \ldots \ldots \ldots \ldots \ldots$

3.0 Composite List of Identified Radionuclides and Chemicals $\ldots \ldots \ldots \ldots \ldots \ldots$

3.1 Risk-Based Standards Database $\ldots \ldots \ldots \ldots \ldots \ldots \ldots \ldots \ldots \ldots \ldots$

3.2 Environmental Sampling Data Reports $\ldots \ldots \ldots \ldots \ldots \ldots \ldots \ldots$

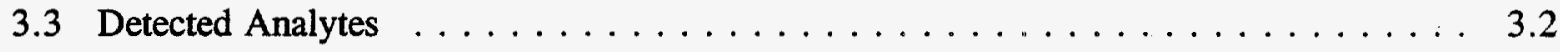

xvii 


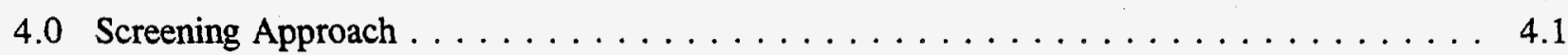

4.1 Screening Equations $\ldots \ldots \ldots \ldots \ldots \ldots \ldots \ldots \ldots \ldots \ldots \ldots \ldots \ldots \ldots \ldots$

4.1 .1 Radionuclide Screening $\ldots \ldots \ldots \ldots \ldots \ldots \ldots \ldots \ldots \ldots .1$

4.1.2 Carcinogenic Chemical Screening $\ldots \ldots \ldots \ldots \ldots \ldots \ldots \ldots .4 .2$

4.1.3 Toxic Chemical Screening $\ldots \ldots \ldots \ldots \ldots \ldots \ldots \ldots \ldots \ldots . \ldots \ldots$

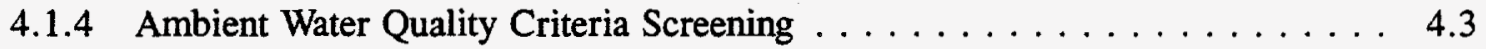

4.1.5 Aquatic Biota Toxicity Screening $\ldots \ldots \ldots \ldots \ldots \ldots \ldots \ldots \ldots . \ldots \ldots$

4.2 Estimation of Contaminant Concentrations in River Water $\ldots \ldots \ldots \ldots \ldots .4$

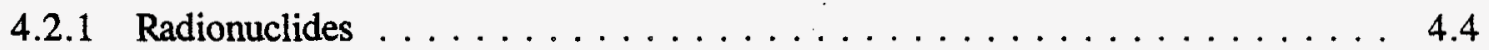

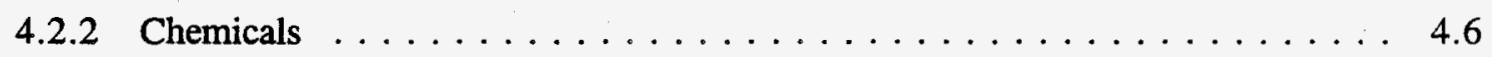

4.3 Screening Results $\ldots \ldots \ldots \ldots \ldots \ldots \ldots \ldots \ldots \ldots \ldots \ldots \ldots .7$

4.3.1 River Water Sample Screening $\ldots \ldots \ldots \ldots \ldots \ldots \ldots \ldots \ldots .7$

4.3.2 Groundwater Sample Screening $\ldots \ldots \ldots \ldots \ldots \ldots \ldots \ldots \ldots . .4$

4.3.3 River Sediment Sample Screening $\ldots \ldots \ldots \ldots \ldots \ldots \ldots \ldots \ldots .4 .8$

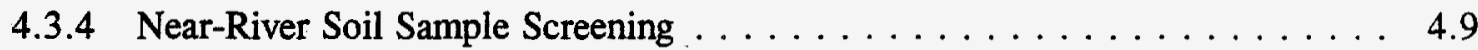

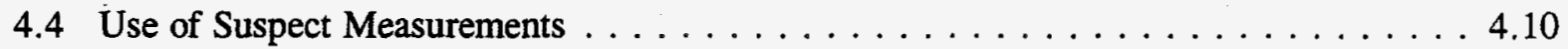

5.0 Discrete Radioactive Particles $\ldots \ldots \ldots \ldots \ldots \ldots \ldots \ldots \ldots \ldots \ldots . \ldots \ldots$

6.0 Direct Irradiation from Hanford Facilities $\ldots \ldots \ldots \ldots \ldots \ldots \ldots \ldots \ldots \ldots . .1$

7.0 Potential Future Groundwater Sources $\ldots \ldots \ldots \ldots \ldots \ldots \ldots \ldots \ldots \ldots . \ldots \ldots$

7.1 Existing Groundwater Plumes $\ldots \ldots \ldots \ldots \ldots \ldots \ldots \ldots \ldots \ldots \ldots \ldots \ldots$

7.2 Potential Future Groundwater Sources $\ldots \ldots \ldots \ldots \ldots \ldots \ldots \ldots \ldots \ldots$

8.0 Materials of Additional Public Interest $\ldots \ldots \ldots \ldots \ldots \ldots \ldots \ldots \ldots \ldots \ldots \ldots \ldots$

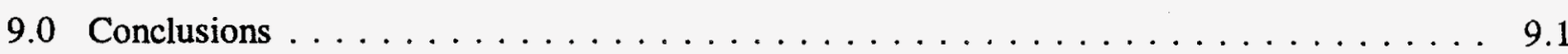


10.0 Perspective

11.0 References

Appendix A - Complete List of Analytes Evaluated at Hanford

Appendix B - Parameter Values Used in Screening Analyses $\ldots \ldots \ldots \ldots \ldots$. . . . . . . B.1

Appendix C - Complete Numerical Results

C. 1

\section{Figures}

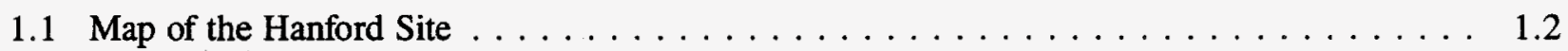

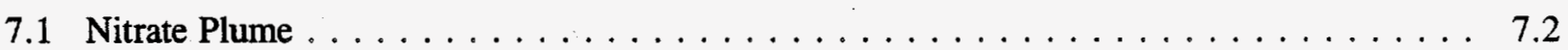

\section{Tables}

S.1 List of Identified Contaminants of Concern $\ldots \ldots \ldots \ldots \ldots \ldots \ldots \ldots \ldots \ldots \ldots \ldots$

3.1 Maximum Detected Concentrations in the Columbia River and Groundwater in the Hanford Site 100, 300, and 1100 Areas Near the Columbia River, 1980-1994 . . . . . 3.3

3.2 Maximum Detected Concentrations in Soil and Sediment in the Hanford Site 100, 300 , and 1100 Areas, 1980-1994

3.3 Maximum Detected Concentrations in Groundwater in the Hanford Site 100, 200, and 600 Areas Away from the Columbia River, 1980-1994

4.1 Contaminants of Potential Interest Identified via Screening of Columbia River Samples _ . . 4.8

4.2 Contaminants of Potential Interest Identified via Screening of Groundwater Near the Columbia River

4.3 Contaminants of Potential Interest Identified via Screening of Columbia River Sediment Samples

4.4 Contaminants of Potential Interest Identified via Screening of Soil Near the Columbia River 
7.1 Contaminants of Potential Interest Identified via Screening of Groundwater Away from

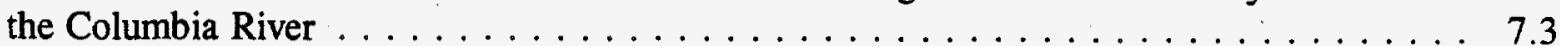

9.1 List of Identified Contaminants of Concern $\ldots \ldots \ldots \ldots \ldots \ldots \ldots \ldots$

A.1 Radionuclide and Chemical Activity/Concentrations in the Columbia River and Groundwater Near the Columbia River $\ldots \ldots \ldots \ldots \ldots \ldots \ldots \ldots \ldots \ldots \ldots \ldots$ A.2

A.2 Radionuclide and Chemical Activity/Concentrations in Soil and Sediment $\ldots \ldots \ldots$ A.11

A.3 Maximum Detected Concentrations in Groundwater in the Hanford Site 100, 200, and 600 Areas Away from the Columbia River, 1980-1994 . . . . . . . . . . . . . . . . A.21

B.1 Parameters Used to Screen the Columbia River and Groundwater Near the Columbia River

B.2 Parameters Used to Screen Soil and Sediment $\ldots \ldots \ldots \ldots \ldots \ldots \ldots \ldots$

B.3 Parameters Used to Screen Groundwater Away from the Columbia River . . . . . . . . . B.7

C.1 Results for the Columbia River and Groundwater Near the Columbia River $\ldots \ldots \ldots$. . . .

C.2 Results for Soil and Sediment $\ldots \ldots \ldots \ldots \ldots \ldots \ldots \ldots \ldots \ldots \ldots \ldots \ldots \ldots \ldots$

C.3 Results for Groundwater Away from the Columbia River $\ldots \ldots \ldots \ldots \ldots \ldots \ldots$ 


\subsection{Introduction}

Pacific Northwest Laboratory (PNL) is conducting a comprehensive assessment of the Columbia River. The purpose of the Columbia River Comprehensive Impact Assessment (CRCIA) Project is to evaluate the current human and ecological risk from radioactive and other hazardous materials in the Columbia River as a result of past and present activities at the Hanford Site near Richland, Washington. Many thousands of radionuclides and hazardous chemicals ${ }^{(a)}$ have been generated or used at Hanford over the past five decades, only some of which may be of current concern for human or ecological risk. The intent of this report is to focus the resources of the project on the contaminants of greatest concern.

\subsection{Background}

The Hanford Site in southcentral Washington State was acquired by the federal government in 1943 and was dedicated for many years to the production of plutonium for national defense and the management of resulting wastes. The production of nuclear materials for weapons ended at Hanford in 1987. With the shutdown of the production facilities, missions were diversified to include research and development in the areas of energy, waste management, and environmental restoration.

The Hanford Site is about 1,450 square kilometers (560 square miles) of semi-arid shrub-steppe located just north of the confluence of the Yakima River with the Columbia River (Figure 1.1). Approximately 6 percent of the Hanford Site has been used for operations in the following areas:

- 100-B/C, 100-D, 100-F, 100-H, 100-K, and 100-N Areas, which lie along the Columbia River in the northern portion of the Hanford Site, are the sites of the nine Hanford plutonium production reactors (now shut down)

- 200-East and 200-West Areas, which lie in the center of the Hanford Site, are the sites of the chemical reprocessing facilities and low-level- and high-level-waste management facilities

- 300 Area, near the southern border of the Hanford Site, is the site used for nuclear fuel manufacturing and research facilities

- 400 Area, between the 200 and 300 Areas, is the site of the Fast Flux Test Facility

- 1100 Area and 3000 Area, a corridor northwest of the city of Richland, are sites used for warehousing, vehicle maintenance, transportation operations center, construction, engineering, and research and development activities.

(a) In this report, organic chemicals, inorganic chemicals, ions, elements, and other chemical compounds are simply referred to as chemicals. 


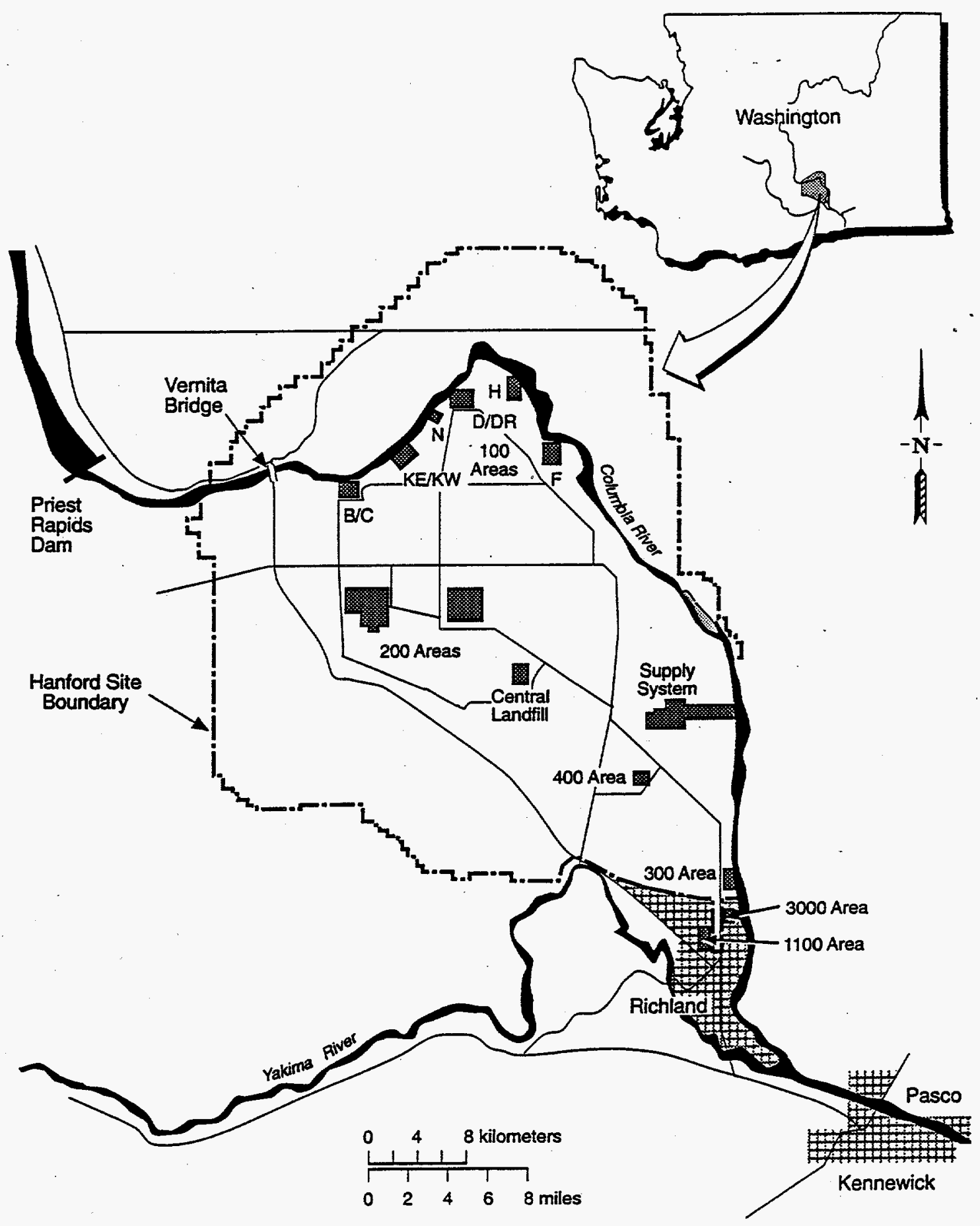

\$9501004.1

Figure 1.1. Map of the Hanford Site 
Fifty-one miles of the Columbia River, known as the Hanford Reach, flows through or borders the Hanford Site. The Hanford Reach is roughly from Priest Rapids Dam to the confluence of the Yakima River with the Columbia River. This stretch of the river offers a unique example of the river and riparian (riverside) ecologies that characterized the Columbia Basin ecosystem prior to construction of hydroelectric dams on the river. The Hanford Reach comprises the last unimpounded stretch of the Columbia River in the United States. Nearly 60 percent of the Columbia River's native wild stock of fall chinook salmon spawn in the reach (National Parks Service 1992). River water is used downstream from the Hanford Site by Washington and Oregon residents for drinking water, agriculture, industry, transportation, and recreation. The riverbanks and islands provide habitat for several species of threatened or endangered plants (e.g., Columbia milkvetch and Hoover's desert parsley) and animals (e.g., bald eagles) (National Parks Service 1992).

Plutonium production operations in the 100 Areas historically have resulted in releases of contaminants directly to the Columbia River and left extensive contamination in some areas of the surface soil, subsurface soil, and groundwater. Contamination reaches the river through groundwater seepage.

Facilities in the 200 Areas were built to process irradiated fuel from the production reactors. The subsequent operation of these facilities resulted in the storage, disposal, and some releases of radioactive and nonradioactive wastes to the environment. Contamination exists in the surface, subsurface, and groundwater in the 200 Areas. Contaminated groundwater has moved out of the operating areas into areas adjoining the operating areas.

The 300 Area is the site of former reactor fuel processing activities. The 300 Area is also the location of nuclear research and development facilities serving the Hanford Site. Wastes in the 300 Area have resulted from the fuel fabrication process and various research activities. Contamination exists in the surface, subsurface, and groundwater.

The 1100 Area just north of Richland serves as the warehousing, vehicle maintenance, and transportation operations center for the Hanford Site. Wastes present result primarily from disposal of batteries, paints and solvents, and antifreeze. Immediately adjacent to the 1100 Area is the 3000 Area, home of Hanford Site engineering, construction, and research and development activities. Minor chemical contamination from paints, solvents, and related activities is also present here.

The 600 Area is defined to include all land within the Hanford Site not occupied by the 100,200 , $300,400,1100$, and 3000 Areas. Lands uses within the 600 Area include a 41 -hectare $(100$-acre) tract subleased from the state of Washington for the disposal of commercial low-level nuclear waste and nuclear power facilities operated by the Washington Public Power Supply System. Most contamination in the 600 Area reaches the Columbia River by groundwater.

\subsection{Purpose}

This report documents an initial review of the abundance of historical data concerning contamination, current or potential, of the Columbia River. The initial review focuses on the availability of key data for particular contaminants at specific locations in specific media. The result is a list of 
contaminants of concern for current human or ecological risk. The list will help focus the effects of health risk assessments because the contaminants on this list are those with the highest risk levels.

The list of contaminants of concern will also be used to help define future sampling requirements to obtain current data for use in the CRCIA Project.

\subsection{Scope}

This study is primarily concerned with the current risks from contaminants of Hanford origin. Therefore, the most recent sampling data are used to provide the applicable source term for the risk calculations. For this study, the focus is on the Columbia River water, sediment, soil, and groundwater within 150 meters ( 500 feet) of the Columbia River, which means a spatial focus on the Hanford 100,300 , and 1100 Areas. A multi-stage screening process was developed to prioritize these various sources in terms of human health risk and ecosystem risk. Each stage of the process identifies pollutants of interest. The combined results of the total screening then compose the total list of concern.

The potential is also addressed for radiation doses arising from discrete radioactive particles in the river sediment or from direct irradiation from near-river Hanford facilities.

Although the primary concern is the current status of the Columbia River, additional consideration is given to the potential for future impact by contaminants currently present in the Hanford Site groundwater. Consideration is not given to the potential impact of contaminants that may be in soils or facilities away from the Columbia River but that are not presently in the groundwater.

\subsection{Preview of Report}

The references used as data sources are annotated in Section 2.0 of this report. A composite list of radionuclides and chemicals identified as being present in environmental samples is presented in Section 3.0. The numerical approach to screening the several hundred analytes into a short list of contaminants of concern is presented in Section 4.0. The results of the screening process are listed in Section 4.3. A discussion of discrete radioactive particles in the sediment of the Columbia River shoreline and islands is given in Section 5.0. Section 6.0 addresses direct gamma irradiation from Hanford facilities located adjacent to the river. Section 7.0 addresses existing and potential future contaminants from groundwater sources away from the river. Contaminants of possible continued public interest are acknowledged in Section 8.0. The overall conclusions, listed as the contaminants of concern, are given in Section 9.0. Supporting material is made available in the appendices at the end of the report. 


\subsection{Data Sources}

An annotated bibliography of the sources used to identify the analytes sampled in environmental media are provided in this section. No single document or electronic database was available that covered the entire scope of contaminants for this research. Baseline efforts similar to the scope of our task were done in a project by Fowler et al. (1993). However, because that project covered all exposure pathways and numerous U.S. Department of Energy (DOE) sites, and identified only the presence of contaminants and not their concentrations, it is not directly applicable or as comprehensive as required for this task.

The CRCIA Project developed a compendium of existing data on Columbia River contamination (Eslinger et al. 1994). The compendium is a large bibliography of Hanford and non-Hanford sources that potentially contain relevant environmental monitoring information. This compendium was used as a starting point for data information.

This study is primarily concerned with the current risks from contaminants of Hanford origin. Therefore, the most recent sampling data provide the source term for the risk calculations. A secondary concern of this study is the potential for future contamination of the river from Hanford facilities away from the river. Summary information related to existing groundwater plumes that are farther than 150 meters (500 feet) from the Columbia River on the Hanford Site was also reviewed.

To understand some of the key terms in the bibliography, it is necessary to know that the radioactive, hazardous chemical, and mixed wastes are found in various individual waste sites, referred to as waste management units, located throughout the Hanford Site. These individual waste management units include past practice sites; surplus facilities; and treatment, storage, and disposal (TSD) facilities. Past practice sites and TSD facilities may take the form of spills, cribs, ditches, ponds, tanks, trenches, landfills, burial grounds, pits, French drains, and other means of intentional or unintentional disposal. Surplus facilities include contaminated buildings, exhaust stacks, and underground transfer lines. The individual waste management units are organized into "operable units" based on geographic proximity or similarity of waste disposal history.

The following annotated bibliography summarizes the sampling data sources and primary references used in the compilation of the monitoring data. The complete reference, sampling purpose, sampling time frame, media sampled, as well as supplementary comments, are provided. Documents of specific types are listed together, in alphabetical order. Appendix A presents a complete list of radionuclides and chemicals evaluated at Hanford.

\subsection{General References}

Dirkes, R. L. 1993. Columbia River Monitoring: Distribution of Tritium in Columbia River Water at the Richland Pumphouse. PNL-8531, Pacific Northwest Laboratory, Richland, Washington.

This document reports the results of a special investigation conducted by the PNL Surface Environmental Surveillance Project. Supplemental monitoring of tritium (hydrogen-3) in the Columbia River 
was conducted in the summers of 1987 and 1988. The purpose of the monitoring was to provide information related to the dispersion and distribution of Hanford-originating contaminants entering the river through the seepage of groundwater along the Hanford Site.

Dirkes, R. L. 1994. Summary of Radiological Monitoring of Columbia River Water along the Hanford Reach, 1980 through 1989. PNL-9223, Pacific Northwest Laboratory, Richland, Washington.

A portion of PNL's Surface Environmental Surveillance Project is involved with monitoring the Columbia River. This document summarizes the river water monitoring activities of the Columbia River monitoring program during the 1980 s. Routine and special monitoring projects and radiological and chemical constituents are reviewed. This report summarizes the information presented in the annual environmental reports.

Dirkes, R. L., G. W. Patton, and B. L. Tiller. 1993. Columbia River Monitoring: Summary of Chemical Monitoring Along Cross Sections at Vernita Bridge and Richland. PNL-8654, Pacific Northwest Laboratory, Richland, Washington.

Chemical monitoring was performed by PNL's Surface Environmental Surveillance Project at the Vernita Bridge and the Richland Pumphouse. Potential Hanford-originating chemicals of interest were selected for sampling; these included volatile organic compounds (VOCs), metals, and anions. Monthly samples were taken from August 1991 to December 1991. The sample frequency was reduced to quarterly during calendar year 1992. The monitoring results were benchmarked with those of the United States Geological Survey monitoring program, and no variants were found.

DOE - U.S. Department of Energy. 1992a. Sampling and Analysis of 100 Area Springs. DOE/RL-92-12, Rev. 1, U.S. Department of Energy, Richland, Washington.

This document provides validated monitoring data from the sampling of the Columbia River, seeps, springs, and sediment adjacent to the Hanford 100 Areas National Priorities List Site. The data were published as part of a Tri-Party Agreement milestone to evaluate how the contaminated seeps and springs impact the Columbia River. An assessment of the data is included. Samples were collected in September and October 1991 during the normal low-flow period of the Columbia River. Twenty-six locations were sampled along a 37-kilometer (22-mile) stretch of the river, ranging from just upstream of the $100-\mathrm{B} / \mathrm{C}$ Area water intake to the old Hanford townsite.

DOE - U.S. Department of Energy. 1992b. Hanford Site Groundwater Background. DOE/RL-92-23, U.S. Department of Energy, Richland, Washington.

This report is a preliminary evaluation of data and information related to the natural composition of groundwater in the unconfined aquifer system beneath the Hanford Site. This information is to be used as a baseline for distinguishing the presence and significance of contamination in the groundwater. The relevant part of the aquifer evaluated extended from the surface waters that potentially recharge the aquifer to the uppermost portion of the underlying confined aquifer. Surface waters were found, in 
general, to have lower concentrations of constituents than the springs, unconfined groundwater, and confined groundwater. The provisional background threshold levels of background constituent concentrations in groundwater that are indicated in this report are likely to be conservatively low.

DOE - U.S. Department of Energy. 1994a. Hanford Site Background: Part 1, Soil Background for Nonradioactive Analytes. DOE/RL-92-24, Rev. 2, Vol. 1 of 2, U.S. Department of Energy, Richland, Washington.

This document was written to support environmental restoration, waste management, and facilities operations activities at Hanford. The background composition of Hanford Site soil is characterized for the purposes of identifying soil contamination and as a baseline in risk assessment processes used to determine soil cleanup and treatment levels. The compositions of naturally occurring soil in the zone above the groundwater level have been determined for nonradioactive inorganic and organic analytes and related physical properties. The range of inorganic and organic analytes that can be expected in Hanford Site background soil is evaluated. The highest measured background concentrations occur in three volumetrically minor soil types, the most important of which is topsoil adjacent to the Columbia River, which are rich in organic carbon. The chemical composition of more than 170 soil samples from 22 places on the Hanford Site and 3 places adjoining the Hanford Site was determined for inorganic analytes in accordance with EPA protocols. Twelve of the samples were analyzed for volatile and semivolatile organic chemicals, as well as for pesticides and polychlorinated biphenyls (PCB). Samples were collected from September through November 1991.

DOE - U.S. Department of Energy. 1994b. Annual Report for RCRA Groundwater Monitoring Projects at Hanford Site Facilities. DOE/RL-93-88, Rev. 0, U.S. Department of Energy, Richland, Washington.

This report is an annual hydrologic evaluation of 20 RCRA groundwater monitoring projects and one nonhazardous waste facility at the Hanford Site. The interpretation of groundwater data collected at 30 waste management units between October 1992 and September 1993 is included. Also, recent groundwater quality evaluations for the 100 and 300 Areas and the entire Hanford Site are described. Widespread contaminants include nitrate, chromium, carbon tetrachloride, tritium (hydrogen-3), and other radionuclides.

Eslinger, P. W., L. R. Huesties, A. D. Maughan, T. B. Miley, and W. H. Walters. 1994. Data Compendium for the Columbia River Impact Assessment. PNL-9785, Pacific Northwest Laboratory, Richland, Washington.

This document provides a bibliography of sources of existing data on Columbia River contamination. Approximately 4,500 documents and 13 major databases are listed that potentially contain information about contaminants in the Columbia River due to Hanford activities. The bibliography was further refined to highlight 60 key documents that contain data or describe analyses important in evaluating the health of the Columbia River. The work was performed to meet the Tri-Party Agreement milestone number $\mathrm{M}-13-80$. 
Ford, B. H. 1993. Groundwater Field Characterization Report for the 200 Aggregate Area Management Study. WHC-SD-EN-TI-020, Westinghouse Hanford Company, Richland, Washington.

This report provides contaminant plume maps for the unconfined aquifer of the 200 East and 200 West groundwater aggregate areas. Data deficiencies are identified with recommendations for additional sampling and well drilling. Individual plumes are identified for arsenic, chromium, cyanide, fluoride, nitrate, carbon tetrachloride, chloroform, trichloroethylene, tritium (hydrogen-3), gross beta, cobalt-60, strontium-90, technetium-99, iodine-129, cesium-137, gross alpha, uranium, and plutonium.

Fowler, K. M., K. B. Miller, M. O. Hogan, and J. F. Donaghue. 1993. Risk-Based Standards Chemicals of Interest Database Documentation. DRAFT. Prepared for the U.S. Department of Energy by the Pacific Northwest Laboratory, Richland, Washington.

A comprehensive set of risk-based standards are needed by the U.S. DOE to conduct its waste management, environmental restoration, and decontamination and decommissioning activities. The first step in developing the standards was to gather information on hazardous and radioactive substances that are found as contaminants or that are stored at DOE facilities. Twenty-six DOE sites were surveyed for substances that are generated, used, or present. Sources of information included Superfund Amendments and Reauthorization Act (SARA) Title III reports, remedial investigation/feasibility study reports, and other miscellaneous sources. The radionuclide and chemical names and media type in which they were found (i.e., air, groundwater, sediment, soil, surface water, tank wastes, and not specified/available) are indicated, but no quantitative sampling results are provided in this document. A total of 326 radionuclides and chemicals were identified for the Hanford Site.

Hartman, M. J., and K. A. Lindsey. 1993. Hydrogeology of the 100-N Area, Hanford Site, Washington. WHC-SD-EN-EV-027, Westinghouse Hanford Company, Richland, Washington.

The report primarily describes the hydrologic units beneath the $100-\mathrm{N}$ Area. It includes descriptions of primary contaminants of interest, including strontium-90 and tritium (hydrogen-3) associated with the liquid waste disposal sites, sulfate and sodium, and petroleum products associated with leaks and spills. A total of eight petroleum (diesel oil) spills are documented between 1966 and 1988 . Following the 1966 leak, an interceptor trench was built to collect migrating diesel oil, where it was periodically burned. A significant amount of free petroleum apparently remains in the zone above groundwater level; as much as 45 centimeters (1.5 feet) of petroleum product has been observed floating on top of the water in some of the monitoring wells. The petroleum seems to appear on the water table following periods of recharge to the aquifer.

Law, A. G. 1990. Status of Groundwater in the 1100 Area. Correspondence No. 8900604B R4, Westinghouse Hanford Company, Richland, Washington.

This document provides the quarterly results from the Westinghouse Hanford Company operational groundwater monitoring program for five wells installed in the vicinity of the 1100 Area. Results for approximately 380 analytes are presented; all are essentially undetected or at background levels. 
Peterson, R. E., and V. G. Johnson. 1992. Riverbank Seepage of Groundwater Along the 100 Areas Shoreline, Hanford Site. WHC-EP-0609, Westinghouse Hanford Company, Richland, Washington.

Data were obtained during environmental surveillance activities and remedial investigations to characterize the influence of contaminated groundwater on the Columbia River. Radionuclides and metals in the seepage, sediment associated with the seepage, and near-shore Columbia River water were sampled. Samples collected in September and October of 1991 are compared with data collected in 1984 and 1988, as well as nearby groundwater data.

Rowley, C. A. 1993. 100-N Area Underground Storage Tank Closures. WHC-SD-EN-TI-136, Westinghouse Hanford Company, Richland, Washington.

This report describes removal/characterization actions concerning underground petroleum storage tanks in the 100-N Area undertaken from 1990 through 1992. Instances of leaks from underground connections are noted. No groundwater contamination was found resulting from these tanks.

Weiss, S. G. 1993. 100 Area Columbia River Sediment Sampling. WHC-SD-EN-TI-198, Rev. 0, Westinghouse Hanford Company, Richland, Washington.

To determine whether radiological and chemical contaminants are present in the Columbia River, 44 sediment samples were collected from 28 locations in the Hanford Reach in the fall of 1992. The sand-sized and smaller sediment samples were analyzed for metals and radionuclides from the nearshore and shoreline. Three of the sample locations were upriver from Hanford. Sediment was collected at depths of 0-15 centimeters (0-6 inches) and 30-60 centimeters (12-24 inches) below the surface. Contamination from arsenic, chromium, copper, lead, and zinc was found. The arsenic, lead, and zinc contamination may not be of Hanford origin. Cesium-137 and europium-152 were the most frequently detected radionuclides.

Wells, D. 1994. Radioactivity in Columbia River Sediments and their Health Effects. Special Report, Washington State Department of Health, Olympia, Washington.

This document addresses the current human health effects of artificial radioactivity in the Columbia River sediment. The Columbia River sediment data from the early 1960 s to the present were provided by state agencies, federal agencies, and academic researchers. The sediment samples were collected from the Hanford area to the estuaries and coastlines of Oregon and Washington. Samples include surface sediment and deeper sediment behind the dams of the lower Columbia River. Ecological risks were not evaluated; nor were the human health risks from sediment contaminated with radioactive materials entering the Columbia River at riverbank seeps and springs. 


\subsection{Hanford Environmental Information System}

DOE - U.S. Department of Energy. 1994c. HEIS - Hanford Environmental Information System. For documentation supporting the HEIS database, see DOE/RL-93-24, 9 volumes, U.S. Department of Energy, Richland, Washington. Queried: August 24, 1994.

The Hanford Environmental Information System (HEIS) is an electronic database that consolidates the data gathered during environmental monitoring and restoration of the Hanford Site. Data stored in HEIS are collected under several regulatory programs. The basis of HEIS is individual sample data for air, biota, groundwater, soil, sediment, surface water, and miscellaneous materials. The HEIS system was queried for information about maximum contaminant concentrations in groundwater within 150 meters (500 feet) of the Columbia River.

\subsection{Remedial Investigation/Feasibility Studies}

The EPA is the lead regulatory agency for the Comprehensive Environmental Response, Compensation, and Liability Act of 1980 (CERCLA). Under CERCLA, a specific process has been established to identify potentially hazardous sites, characterize site contamination, assess treatment technologies, and then design and construct the appropriate treatment facilities. The remedial investigation/feasibility study (RI/FS) portion of the process defined in CERCLA requires determining the nature and extent of the threat posed by a release of hazardous substances to the environment and evaluating proposed remedies. The RI/FS studies which contributed information to the CRCIA Project are:

DOE - U.S. Department of Energy. 1990a. Remedial Investigation/Feasibility Study Work Plan for the 300-FF-5 Operable Unit, Hanford Site, Richland, Washington. DOE/RL 89-14, U.S. Department of Energy, Richland, Washington.

The 300-FF-5 operable unit consists of the groundwater aquifer beneath the 300-FF-1, 300-FF-2, and 300-FF-3 source operable units and adjacent areas defined by the extent of the groundwater contamination. The scope of the 300-FF-5 operable unit RI/FS focuses on groundwater, soil, surface water/ sediment and aquatic biota and considers all contaminant sources in the 300 Area that contribute to the existing groundwater contamination beneath the 300 Area and the surrounding environment. The sample data upon which the RI/FS is based appear to have been taken in the mid-1980s. Groundwater monitoring for metals began in 1985.

DOE - U.S. Department of Energy. 1990b. Remedial Investigation/Feasibility Study Work Plan for the 300-FF-1 Operable Unit, Hanford Site, Richland, Washington. DOE/RL 89-31, U.S. Department of Energy, Richland, Washington.

The purpose of the 300-FF-1 operable unit remedial investigation was to provide sufficient information to conduct the feasibility study by determining the nature and extent of the threat to public health and the environment posed by releases of hazardous substances from 300-FF-1, a process liquid operable unit that contains all the liquid waste disposal facilities within the 300 Area. Hazardous and radioactive 
materials from this operable unit contribute to groundwater contamination. Soil sampling data are provided for radionuclides, inorganics, and an extensive list of organics. Monitoring of groundwater analytes was more limited.

\subsection{Hanford Site Environmental Reports}

Every year, beginning in 1957 , a report is prepared that summarizes environmental data, which characterize the Hanford Site environmental management performance and demonstrate compliance status. These reports summarize the activities and results of monitoring by the Surface Environmental Surveillance Project. In recent years, data have been provided in separate volumes. Annual reports used in the development of this project include the following:

Bisping, L. E. 1994. Hanford Site Environmental Data for Calendar Year 1993 - Surface and Columbia River. PNL-9824, Pacific Northwest Laboratory, Richland, Washington.

Bisping, L. E., and R. K. Woodruff. 1993. Hanford Site Environmental Data for Calendar Year 1992 - Surface and Columbia River. PNL-8683, Pacific Northwest Laboratory, Richland, Washington.

Bisping, L. E. 1992. Hanford Site Environmental Data 1991 - Surface and Columbia River. PNL-8149, Pacific Northwest Laboratory, Richland, Washington.

Dirkes, R. L., R. W. Hanf, R. K. Woodruff, and R. E. Lundgren. 1994. Hanford Site Environmental Report for Calendar Year 1993. PNL-9823, Pacific Northwest Laboratory, Richland, Washington.

Woodruff, R. K., R. W. Hanf, and R. E. Lundgren. 1993. Hanford Site Environmental Report for Calendar Year 1992. PNL-8682, Pacific Northwest Laboratory, Richland, Washington.

Woodruff, R. K., R. W. Hanf, and R. E. Lundgren. 1992. Hanford Site Environmental Report for Calendar Year 1991. PNL-8148, Pacific Northwest Laboratory, Richland, Washington.

\subsection{Limited Field Investigations}

Limited Field Investigations (LFIs) are conducted as part of Tri-Party Agreement activities to identify those Hanford waste sites that are recommended to remain as candidates for interim remedial measures. The assessments include consideration of whether contaminant concentrations pose an unacceptable risk that warrants action through interim remedial measures.

Each LFI is conducted on a single Hanford operable unit (e.g., operable unit 100-HR-3). Operable unit is the term used to identify specific areas designated for cleanup. The number and first letter in the operable unit name indicate the location of the operable unit; operable unit 100-HR-3 is in the 100-H Area. Many of the column headings in Appendix A correspond to the operable unit name. 
The LFI reports annotated in this section are available to the public. The following list of LFI reports are those identified by Westinghouse Hanford Company's Environmental Data Management Control as undergoing final review and so not yet available to the public:

\begin{tabular}{|c|c|}
\hline Operable Unit & Document Numbe \\
\hline 100-FR-3 & DOE\RL-93-83 \\
\hline 100-FR-1 & DOE $\backslash R L-93-02$ \\
\hline $100-N R-2$ & DOE $\backslash R L-93-81$ \\
\hline $100-B C-2$ & DOE $\backslash R L-94-42$ \\
\hline $100-H R-2$ & DOE $\backslash R L-94-53$ \\
\hline
\end{tabular}

DOE - U.S. Department of Energy. 1994d. Limited Field Investigation Report for the 100-BC-1 Operable Unit. DOE/RL-93-06, U.S. Department of Energy, Richland, Washington.

This study was initiated to characterize the liquid and sludge at disposal sites associated with the B Reactor in the 100-BC Area. Groundwater sampling data are contained in the LFI, 100-BC-5 (see below). Surface water and sediment sampling are not applicable to the 100-BC-1 area. Media were sampled for VOCs, semivolatiles, inorganics, metals, PCBs, pesticides, radionuclides, and physical properties. Sampling data were collected from April 1992 through July 1992.

DOE - U.S. Department of Energy. 1993a. Limited Field Investigation Report for the 100-BC-5 Operable Unit. DOE/RL-93-37, Draft A, U.S. Department of Energy, Richland, Washington.

This study was initiated to further characterize the groundwater contamination in the 100-BC Area. Groundwater, surface water, sediment, and soil sampling data are provided. Volatile constituent concentrations were of primary interest, but the media were also sampled for radionuclides, organics, inorganics, and physical properties. The LFI groundwater sampling data are reported for July 1992, October 1992, and January 1993.

DOE - U.S. Department of Energy. 1993b. Limited Field Investigation Report for the 100-DR-1 Operable Unit. DOE/RL-93-29, Draft A, U.S. Department of Energy, Richland, Washington.

The purpose of this study was to characterize the waste facility sites associated with the D Reactor and the water retention basin systems for both the D and DR Reactors and in the 100-DR Area. Soil sampling results are reported. Groundwater sampling data for this same region are contained in the LFI, 100-HR-3 (see below). Media were sampled for VOCs, semivolatiles, inorganics, metals, PCBs, pesticides, radionuclides, specific anions, hexavalent chromium, and physical properties. Samples were collected in March 1993. 
DOE - U.S. Department of Energy. 1993c. Limited Field Investigation Report for the 100-HR-1 Operable Unit. DOE/RL-93-51, Draft A, U.S. Department of Energy, Richland, Washington.

This study was initiated to characterize the waste units associated with facility sites supporting the $\mathrm{H}$ Reactor in the 100-H Area. This document provides sludge, sediment, and soil sampling data. Groundwater sampling data are contained in the LFI, 100-HR-3 (see below). Media were sampled for VOCs, semivolatiles, inorganics, metals, PCBs, pesticides, radionuclides, and physical properties. The media were sampled from December 1991 through August 1992.

DOE - U.S. Department of Energy. 1993d. Limited Field Investigation Report for the 100-HR-3 Operable Unit. DOE/RL-93-43, Draft A, U.S. Department of Energy, Richland, Washington.

This study was initiated to further characterize the groundwater contamination in the 100-HR-3 operable unit, which is inclusive of three sub-areas: 100-D, 100-H, and the 600 Area between the D and $\mathrm{H}$ Reactor areas. This document provides groundwater, sediment and soil sampling data for radionuclides, volatile and semivolatile organic compounds, inorganics, and pesticides. Media were sampled from May 1992 through March 1993.

DOE - U.S. Department of Energy. 1994e. Limited Field Investigation Report for the 100-KR-1 Operable Unit. DOE/RL-93-78, Draft A, U.S. Department of Energy, Richland, Washington.

- This document provides soil sampling data. Groundwater sampling data are contained in the LFI, 100-KR-4 (see below). Surface water and sediment sampling are not applicable to the 100-KR-1 operable unit. Media were sampled for VOCs, inorganics, metals, radionuclides, hexavalent chromium, and physical properties. Samples were taken from October 1992 through March 1993.

DOE - U.S. Department of Energy. 1994f. Limited Field Investigation Report for the 100-KR-4 Operable Unit. DOE/RL-93-79, U.S. Department of Energy, Richland, Washington.

This LFI was initiated to further characterize the groundwater contamination in the 100-KR area operable units: $100-\mathrm{KR}-1,100-\mathrm{KR}-2$, and 100-KR-3. In addition to the groundwater samples, other sampling data include surface water, sediment, soil, and aquatic biotic impacted by the $\mathrm{KE}$ and $\mathrm{KW}$ reactors. The media were sampled for VOCs, semivolatiles, inorganics, metals, pesticides, and radionuclides. Samples were collected in October 1991, September 1992, December 1992, March 1993, and June 1993.

\subsection{Discrete Radioactive Particles and Other Direct Exposure Sources}

In addition to the routine environmental monitoring documented in the Hanford Site annual reports, occasional special studies are performed to evaluate particular conditions. Key studies are described here. 
Cooper, A. T., and R. K. Woodruff. 1993. Investigation of Exposure Rates and Radionuclide and Trace Metal Distributions Along the Hanford Reach of the Columbia River. PNL-8789, Pacific Northwest Laboratory, Richland, Washington.

This report documents the first major field study to investigate exposure rates along the Columbia River shoreline since the Sula (1980) investigation of 1979. Radionuclides and trace metals were surveyed between Priest Rapids Dam and north Richland. A smaller number of discrete radioactive particles were also noted.

EG\&G Energy Measurements. 1990. An Aerial Radiological Survey of the Hanford Site and Surrounding Area, Richland, Washington. EGG-10617-1062, EG\&G Energy Measurements, The Remote Sensing Laboratory, Las Vegas, Nevada.

EG\&G used a radiation detection system in a helicopter to conduct a radiological survey of the Hanford area. The detection system was calibrated to suppress natural background radiation and therefore only detected sources of anthropomorphic gamma-emitting radioactivity. The aerial data are presented as isopleths overlaid onto maps of the Hanford Site. The aerial survey is an aid in locating areas with elevated exposure rates but does not stringently define contaminated areas.

Sula, M. J. 1980. Radiological Survey of Exposed Shorelines and Islands of the Columbia River Between Vernita and the Snake River Confluence. PNL-3127, Pacific Northwest Laboratory, Richland, Washington.

This report describes a radiological survey performed to evaluate the magnitude and distribution of radioactive contamination on the exposed shorelines of the Columbia River. External exposure rate measurements were made at nearly 30,000 locations. In addition, discrete particles of radioactive material were discovered. Discrete metallic flakes containing cobalt-60 were found. The highest areal density of particles was found on an island near D-reactor, although the presence of particles was indicated as far downriver as the survey extended.

Wade, C. D., and M. A. Wendling. 1994. 100-D Island USRADS Radiological Surveys Preliminary Report Phase II. BHI-00-134, Bechtel Hanford, Inc., Richland, Washington.

This report describes the results of radiological surveys made in April 1994, over the upstream third of the island adjacent to the 100-D reactor area. The survey used the Ultrasonic Ranging and Data System. A significant note is that, "with a few exceptions, every area which was determined to be gamma elevated was sampled and the sampling removed the entire contamination present. In these locations, extremely small 'hot particles' were removed from the silt layer beneath the river rock." Analyses of these particles showed them to contain almost entirely cobalt- 60 activity, between 0.4 and 22 microcuries each. A total of 103 particles were recovered from an area of about 5 hectares (12.5 acres). 


\subsection{National Environmental Policy Act (NEPA) Documents}

Quantifying the potential for future releases of contaminants to the Columbia River from surplus facilities or waste sites requires a significant investigation, one which is beyond the scope of this report. However, several major environmental impact statements (EIS) concerning Hanford facilities and waste management practices have been written. Each of these reports contains evaluations of potential future conditions based on current or projected Hanford Site status.

DOE - U.S. Department of Energy. 1987. Final Environmental Impact Statement, Disposal of Hanford Defense High-Level, Transuranic, and Tank Wastes, Hanford Site, Richland, Washington. DOE/EIS-0113, U.S. Department of Energy, Washington, D.C.

This EIS addressed the selection and implementation of final disposal actions for high-level, transuranic, and tank wastes at Hanford. Although a decision on the existing single-shell tanks was ultimately deferred, this EIS provides descriptions of the potential releases of radionuclides to the groundwater, and ultimately the Columbia River, for each of the major waste categories at Hanford.

DOE - U.S. Department of Energy. 1989. Decommissioning of Eight Surplus Production Reactors at the Hanford Site, Richland, Washington, Draft Environmental Impact Statement. DOE/EIS-0119D, U.S. Department of Energy, Washington, D.C.

and

DOE - U.S. Department of Energy. 1992c. Decommissioning of Eight Surplus Production Reactors at the Hanford Site, Richland, Washington, (Final Environmental Impact Statement). DOE/EIS-0119F, U.S. Department of Energy, Washington, D.C.

This EIS, together with its addendum which constitutes the final EIS, describes the potential future releases of radionuclides to groundwater, and ultimately the Columbia River, from decommissioning the eight original Hanford reactors (excluding $N$ Reactor) and the associated fuel storage basins. The preferred alternative for disposal was selected to be one-piece removal of the reactors from the riverside and burial in the 200 Areas.

DOE - U.S. Department of Energy. 1990c. Low-Level Burial Grounds Dangerous Waste Permit Application: Request for Exemption from Lined Trench Requirements for Submarine Reactor Compartments. DOE/RL-88-20, Supplement 1, U.S. Department of Energy, Richland, Washington.

and

DOE - U.S. Department of Energy. 1992d. Low-Level Burial Grounds Dangerous Waste Permit Application: Request for Exemption from Lined Trench Requirements and from Land Disposal Restrictions for Residual Liquid at 218-E-12B Burial Ground Trench 94. DOE/RL-88-20, Supplement 1, Revision 1, U.S. Department of Energy, Richland, Washington. 
These two reports discuss decommissioned, defueled naval submarine reactor compartments containing radioactivity caused by exposure of structural components to neutrons during normal operation of the submarines. After all the alternatives were evaluated in the U.S. Department of the Navy 1984 environmental impact statement (Navy 1984), land burial of the submarine reactor compartments was selected as the preferred disposal option. The reactor compartments currently are sent to Trench 94 of the Hanford 218-E-12B Burial Ground. In addition to radioactivity, the reactor compartments disposed contain lead and PCBs as hazardous constituents. Modeling results indicate that release of contaminants to the groundwater or surface water will not occur until after long periods of time and that even after reaching the groundwater, contaminants will not be in excess of current regulatory limits, such as drinking water standards.

DOE - U.S. Department of Energy. 1994g. Hanford Remedial Action Draft Environmental Impact Statement. DOE/DEIS-0222. U.S. Department of Energy, Washington, D.C.

This EIS provides estimates of long-term risk resulting from the current groundwater plumes existing beneath the Site, as well as projections of future risks from non-tank, non-operating-facility waste management units.

Navy - U.S. Department of the Navy. 1984. Final Environmental Impact Statement on the Disposal of Decommissioned, Defueled Naval Submarine Reactor Plants. U.S. Department of the Navy, Washington, D.C.

This EIS discusses various alternatives for disposal of the radioactive portions of decommissioned nuclear submarines, leading to the selection of the Hanford Site as the location for permanent disposal. Estimates are presented for potential future radiation doses resulting from these activities.

Rhoads, K., B. N. Bjornstad, R. E. Lewis, S. S. Teel, K. J. Cantrell, R. J. Serne, J. L. Smoot, C. T. Kincaid, and S. K. Wurstner. 1992. Estimation of the Release and Migration of Lead Through Soils and Groundwater at the Hanford Site 218-E-12B Burial Ground. PNL-8356 Vol. 1, Pacific Northwest Laboratory, Richland, Washington.

This report evaluates the potential for radioactive and nonradioactive lead to migrate from buried submarine reactor compartments to the Columbia River. The estimated time of arrival of the contaminant plume ranges from 60,000 years to 4 million years.

Rhoads, K. , B. N. Bjornstad, R. E. Lewis, S. S. Teel, K. J. Cantrell, R. J. Serne, L. H. Sawyer, J. L. Smoot, J. E. Szecsody, M. S. Wigmosta, and S. K. Wurstner. 1994. Estimation of the Release and Migration of Nickel Through Soils and Groundwater at the Hanford Site 218-E-12B Burial Ground. PNL-9791, Pacific Northwest Laboratory, Richland, Washington.

This report evaluates the potential for radioactive and nonradioactive nickel to migrate from buried submarine reactor compartments to the Columbia River. The estimated time of arrival of the contaminant plume ranges from 60,000 years to 4 million years. 


\subsection{Composite List of Identified Radionuclides and Chemicals}

A data matrix (see Appendix A) was developed using the information found in the documents listed in Section 2.0. All radionuclides and chemicals analyzed in surface water (the Columbia River, springs, and seeps), sediment, groundwater, and soil samples in the 100, 300, and 1100 Areas are included. The data matrix is a composite list of all detected and not detected (i.e., analyzed for but not detected), radionuclides and chemicals from the reviewed literature. Sampling data from 1980 through 1994 were considered.

\subsection{Risk-Based Standards Database}

The development of the data matrix began with all chemicals identified in the Risk-Based Standards Database (Fowler et al. 1993). The Risk-Based Standards Database is a list of hazardous and radioactive substances reportedly found as contaminants or that are stored at DOE facilities nationwide. There are a total of 326 radionuclide and chemical entries for the Hanford Site. The radionuclides and chemicals in the database are sorted by their presence in the following media: Columbia River water, groundwater, soil, air, tank waste, and sediment. A total of 120 organic compounds, 133 inorganics, and 73 radionuclides were identified. These data formed the early basis for the data matrix.

Duplicate entries were removed from the database. Three mixtures (diesel fuel, hydrocarbons, and kerosene) are included. The primary database references were consulted for the concentration detected for each media. However, it was not possible to confirm the presence of the organics from the primary references cited in the database. Additional sources were reviewed to obtain information on the organic constituents.

\subsection{Environmental Sampling Data Reports}

The chemical analytical and radioanalytical data collected and presented in published environmental sampling reports were compiled and are presented in the data matrix in Appendix A. These reports include LFI reports, qualitative risk assessments, RI/FS reports, RCRA groundwater monitoring, and special studies reports. The titles and summaries of these documents are contained in Section 2.0. The scope was limited to the 100,300 , and 1100 Areas because they are most likely to have current impact.

The names of all radionuclides and chemicals examined (including those reported as nondetected) were added to the data matrix (Appendix A). The reported maximum concentration or activity, by media, is noted along with the background value, its reference, and the operable unit or geographical area where the sampling occurred. A total of 568 and 560 analytes were reported to be tested for in groundwater/Columbia River and soil/sediment, respectively, in the reviewed literature.

Of the analytes tested, 73 were detected in groundwater or Columbia River water, and 92 were detected in soil and sediment. Many of the analytes found are naturally occurring in groundwater and soil or are present as a result of global radioactive fallout. 
A separate data matrix in Appendix A was prepared for incorporation of data related to existing groundwater plumes in areas outside the area of primary interest (i.e., the 200 Areas and 600 Area groundwater plumes).

\subsection{Detected Analytes}

Table 3.1 lists the 73 radionuclides and chemicals detected and their maximum concentration or activity in groundwater and Columbia River water. These maximum values are used in the screening process described in Section 4.0. Table 3.2 lists the 92 radionuclides and chemicals detected and their maximum concentration or activity in sediment and soil. Table 3.3 lists the maximum concentration or activity reported in existing Hanford groundwater plumes away from the river.

The data on radionuclide activity in sediment were compared with values reported by the Washington State Department of Health (Wells 1994). All contaminants included in Wells (1994) were included in the tables.

Tables 3.1, 3.2, and 3.3 are used in the screening criteria described in Section 4.0. 
Table 3.1. Maximum Detected Concentrations in the Columbia River and Groundwater in the Hanford Site 100, 300, and 1100 Areas Near the Columbia River, 1980-1994

\begin{tabular}{|c|c|c|c|}
\hline & \multirow[b]{2}{*}{ Name of Analyte } & \multicolumn{2}{|c|}{ Concentration in } \\
\hline & & Surface Water & Groundwater \\
\hline 1 & ACETONE & $11 \mu g / L$ (a) & $30 \mu \mathrm{g} / \mathrm{L}$ \\
\hline 2 & ALUMINUM & & $4,810 \mu \mathrm{g} / \mathrm{L}$ \\
\hline 3 & AMERICIUM 241 & & $0.021 \mathrm{pCi} / \mathrm{L}$ (b) \\
\hline 4 & AMMONIA & & $70 \mu \mathrm{g} / \mathrm{L}$ \\
\hline 5 & AMMONIUM & & $1,630 \mu \mathrm{g} / \mathrm{L}$ \\
\hline 6 & ANTIMONY & & $60 \mu \mathrm{g} / \mathrm{L}$ \\
\hline 7 & ANTIMONY 125 & & $20 \mathrm{pCi} / \mathrm{L}$ \\
\hline 8 & ARSENIC & $3.4 \mu \mathrm{g} / \mathrm{L}$ & $17 \mu \mathrm{g} / \mathrm{L}$ \\
\hline 9 & BARIUM & $48.2 \mu \mathrm{g} / \mathrm{L}$ & $719 \mu \mathrm{g} / \mathrm{L}$ \\
\hline 10 & BERYLLIUM & & $6 \mu g / L$ \\
\hline 11 & BEAYLLIUM 7 (c) & & \\
\hline 12 & BIS(2-ETHYLHEXYL) PHTHALATE & & $50 \mu g / L$ \\
\hline 13 & BISMUTH (c) & & \\
\hline 14 & BORON (c) & & \\
\hline 15 & CADMIUM & & $31 \mu \mathrm{g} / \mathrm{L}$ \\
\hline 16 & CALCIUM & $35,900 \mu \mathrm{g} / \mathrm{L}$ & $302,000 \mu \mathrm{gg} / \mathrm{L}$ \\
\hline 17 & CARBON 14 & & $23,000 \mathrm{pCi} / \mathrm{L}$ \\
\hline 18 & CESIUM 134 & $0.012 \mathrm{pCi} / \mathrm{L}$ & \\
\hline 19 & CESIUM 137 & $0.13 \mathrm{pCi} / \mathrm{L}$ & $0.5 \mathrm{pCi} / \mathrm{L}$ \\
\hline 20 & CHLORIDE & $870 \mu \mathrm{g} / \mathrm{L}$ & $122,000 \mu \mathrm{g} / \mathrm{L}$ \\
\hline 21 & CHLOROFORM & & $42 \mathrm{\mu g} / \mathrm{L}$ \\
\hline 22 & CHROMIUM & $22 \mu \mathrm{g} / \mathrm{L}$ & $1.950 \mu \mathrm{gg} / \mathrm{L}$ \\
\hline 23 & COBALT & & $8 \mu \mathrm{g} / \mathrm{L}$ \\
\hline 24 & COBALT 60 & $0.011 \mathrm{pCi} / \mathrm{L}$ & $140 \mathrm{pCi} / \mathrm{L}$ \\
\hline 25 & COPPER & $22 \mu \mathrm{g} / \mathrm{L}$ & $516 \mu \mathrm{g} / \mathrm{L}$ \\
\hline 26 & CYANIDE & & $21.1 \mu \mathrm{g} / \mathrm{L}$ \\
\hline 27 & DICHLOROETHYLENE, 1,2- & & $200 \mu \mathrm{g} / \mathrm{L}$ \\
\hline 28 & DICHLOROETHYLENE, 1,2-tranS- & & $130 \mu \mathrm{g} / \mathrm{L}$ \\
\hline 29 & EUROPIUM 154 & & $2 \mathrm{pCi} / \mathrm{L}$ \\
\hline 30 & FLUORIDE & $150 \mu \mathrm{g} / \mathrm{L}$ & $2,080 \mu \mathrm{g} / \mathrm{L}$ \\
\hline 31 & HYORAZINE & & $7 \mu g / \mathrm{L}$ \\
\hline 32 & IODINE 129 & $0.16 \mathrm{pCi} / \mathrm{L}$ & \\
\hline 33 & IRON & $463 \mathrm{pCi} / \mathrm{L}$. & $37,300 \mathrm{\mu g} / \mathrm{L}$ \\
\hline 34 & LEAD & & $173 \mu \mathrm{gg} / \mathrm{L}$ \\
\hline 35 & LITHIUM (c) & & \\
\hline 36 & MAGNESIUM & $9,860 \mu g / L$ & $55,000 \mu \mathrm{g} / \mathrm{L}$ \\
\hline 37 & MANGANESE & $22.8 \mu \mathrm{g} / \mathrm{h}$ & $400 \mu \mathrm{g} / \mathrm{L}$ \\
\hline 38 & MERCURY & & $8.9 \mu \mathrm{g} / \mathrm{L}$ \\
\hline 39 & METHYL ETHYL KETONE & & $18 \mu \mathrm{g} / \mathrm{L}$ \\
\hline 40 & METHYLENE CHLORIDE & & $3,040 \mu \mathrm{gg} / \mathrm{L}$ \\
\hline
\end{tabular}


Table 3.1. (contd)

\begin{tabular}{|c|c|c|c|}
\hline & \multirow[b]{2}{*}{ Name of Analvte } & \multicolumn{2}{|c|}{ Concentration in } \\
\hline & & Surface Water & Groundwater \\
\hline 41 & NICKEL & $31 \mu g / \mathrm{L}$ & $479 \mu \mathrm{g} / \mathrm{L}$ \\
\hline 42 & NITRATE & $480 \mathrm{\mu g} / \mathrm{L}$ & $90,000 \mu \mathrm{g} / \mathrm{L}$ \\
\hline 43 & NITRITE & & $60,000 \mu \mathrm{g} / \mathrm{L}$ \\
\hline 44 & PHOSPHATE & & $3,240 \mu \mathrm{g} / \mathrm{L}$ \\
\hline 45 & PLUTONIUM 238 & & $0.01 \mathrm{pCi} / \mathrm{L}$ \\
\hline 46 & PLUTONIUM 239 & & $0.03 \mathrm{pCi} / \mathrm{L}$ \\
\hline 47 & POTASSIUM & $2,430 \mu g / L$ & $11,300 \mathrm{~kg} / \mathrm{L}$ \\
\hline 48 & RADIUM 226 & & $0.3 \mathrm{pCi} / \mathrm{L}$ \\
\hline 49 & RUTHENIUM $106+D$ & & $34.4 \mathrm{pCi} / \mathrm{L}$ \\
\hline 50 & SELENIUM & & $17.2 \mu \mathrm{g} / \mathrm{L}$ \\
\hline 51 & SILICON (c) & & \\
\hline 52 & SILVER & & $19 \mu \mathrm{g} / \mathrm{L}$ \\
\hline 53 & SODIUM & $13,800 \mu \mathrm{g} / \mathrm{L}$ & $200,000 \mu \mathrm{g} / \mathrm{L}$ \\
\hline 54 & STRONTIUM & & $310 \mu \mathrm{g} / \mathrm{L}$ \\
\hline 55 & STRONTIUM 90. & $28 \mathrm{pCi} / \mathrm{L}$ & $80,000 \mathrm{pCi} / \mathrm{L}$ \\
\hline 56 & SULFATE & $8,600 \mu \mathrm{g} / \mathrm{L}$ & $600,000 \mu \mathrm{g} / \mathrm{L}$ \\
\hline 57 & SULFIDE & & $3,000 \mu \mathrm{g} / \mathrm{L}$ \\
\hline 58 & ITECHNETIUM 99 & & $2,270 \mathrm{pCi} / \mathrm{L}$ \\
\hline 59 & TETRACHLOROETHYLENE & & $39 \mu \mathrm{g} / \mathrm{L}$ \\
\hline 60 & THALLIUM & & $4 \mathrm{\mu g} / \mathrm{L}$ \\
\hline 61 & THORIUM 228 & & $3 \mathrm{pCi} / \mathrm{L}$ \\
\hline 62 & THORIUM 232 & & $44.5 \mathrm{pCi} / \mathrm{L}$ \\
\hline 63 & TITANIUM (c) & & \\
\hline 64 & TOLUENE & $4.7 \mathrm{pg} / \mathrm{L}$ & $2.9 \mu \mathrm{g} / \mathrm{L}$ \\
\hline 65 & TRICHLOROETHYLENE & & $24.1 \mu \mathrm{g} / \mathrm{L}$ \\
\hline 66 & TRITIUM (HYDROGEN 3) & $4,430 \mathrm{pCi} / \mathrm{L}$ & $1,900,000 \mathrm{pCi} / \mathrm{L}$ \\
\hline 67 & URANIUM 233 & & $3.3 \mathrm{pCi} / \mathrm{L}$ \\
\hline 68 & URANIUM 234 & $18 \mathrm{pCi} / \mathrm{L}$ & $120 \mathrm{pCi} / \mathrm{L}$ \\
\hline 69 & URANIUM 235 & $0.01 \mathrm{pCi} / \mathrm{L}$ & $17 \mathrm{pCi} / \mathrm{L}$ \\
\hline 70 & URANIUM 238 & $19 \mathrm{pCi} / \mathrm{L}$ & $93 \mathrm{pCi} / \mathrm{L}$ \\
\hline 71 & VANADIUM & & $40 \mu \mathrm{g} / \mathrm{L}$ \\
\hline 72 & XYLENE & $4 \mu g / L$ & \\
\hline 73 & ZINC & $11 \mathrm{\mu g} / \mathrm{L}$ & $8,800 \mu \mathrm{g} / \mathrm{L}$ \\
\hline (a) & $\mu g / L=$ micrograms per liter. & & \\
\hline (b) & $\mathrm{pCi} / \mathrm{L}=$ picocuries per liter. & & \\
\hline (c) & Concentrations of these chen & within & \\
\hline & their respectively occurring be & ad levels. & \\
\hline
\end{tabular}


Table 3.2. Maximum Detected Concentrations in Soil and Sediment in the Hanford Site 100, 300, and 1100 Areas, 1980-1994

\begin{tabular}{|c|c|c|c|}
\hline & & \multicolumn{2}{|c|}{ Concentration in } \\
\hline & Name of Analyte & Soil & Sediment \\
\hline & Radionuclides & & \\
\hline 1 & AMERICIUM 241 & $34 \mathrm{pCi} / \mathrm{g}(\mathrm{a})$ & \\
\hline 2 & ANTIMONY 124 & & $1.2 \mathrm{pCi} / \mathrm{g}$ \\
\hline 3 & CARBON 14 & $34 \rho C i / g$ & \\
\hline 4 & CESIUM 134 & $0.04 \mathrm{pCi} / \mathrm{g}$ & $0.29 \mathrm{pCi} / \mathrm{g}$ \\
\hline 5 & CESIUM 137 & $2,900 \mathrm{pCi} / \mathrm{g}$ & $6 \mathrm{pCi} / \mathrm{g}$ \\
\hline 6 & COBALT 60 & $18,000 \mathrm{pCi} / \mathrm{g}$ & $4.9 \mathrm{pCi} / \mathrm{g}$ \\
\hline 7 & EUROPIUM 152 & $59,000 \mathrm{pCi} / \mathrm{g}$ & $2.41 \mathrm{pCi} / \mathrm{g}$ \\
\hline 8 & EUROPIUM 154 & $20,000 \mathrm{pCi} / \mathrm{g}$ & $0.24 \mathrm{pCi} / \mathrm{g}$ \\
\hline 9 & EUROPIUM 155 & $6,200 \mathrm{pCi} / \mathrm{g}$ & $0.32 \mathrm{pCi} / \mathrm{g}$ \\
\hline 10 & NEPTUNIUM 237 & & $0.606 \mathrm{pCi} / \mathrm{g}$ \\
\hline 11 & NICKEL 63 & $20,000 \mathrm{pCi} / \mathrm{g}$ & \\
\hline 12. & PLUTONIUM 238 & $11 \mathrm{pCi} / \mathrm{g}$ & $0.00115 \mathrm{pCi} / \mathrm{g}$ \\
\hline 13 & PLUTONIUM 239 & $230 \mathrm{pCi} / \mathrm{g}$ & $0.071 \mathrm{pCi} / \mathrm{g}$ \\
\hline 14. & PLUTONIUM 240 & (w/Pu239) (b) & \\
\hline 15 & POTASSIUM 40 & $16 \mathrm{pCi} / \mathrm{g}$ & $23 \mathrm{pCi} / \mathrm{g}$ \\
\hline 16 & RADIUM 226 & $3.09 \mathrm{pCi} / \mathrm{g}$ & $1.7 \mathrm{pCi} / \mathrm{g}$ \\
\hline 17 & STRONTIUM 90 & $950 \mathrm{pCi} / \mathrm{g}$ & $207 \mathrm{pCi} / \mathrm{g}$ \\
\hline 18 & TECHNETIUM 99 & $0.67 \mathrm{pCi} / \mathrm{g}$ & $0.5 \mathrm{pCi} / \mathrm{g}$ \\
\hline 19 & THORIUM 228 & $1.61 \mathrm{pCi} / \mathrm{g}$ & $3 \mathrm{pCi} / \mathrm{g}$ \\
\hline 20 & THORIUM 232 & $1.1 \mathrm{pCi} / \mathrm{g}$ & $3.2 \mathrm{pCi} / 9$ \\
\hline 21 & THORIUM 234 & ND (c) & $0.812 \mathrm{pCi} / \mathrm{g}$ \\
\hline 22 & TRITIUM (HYOROGEN 3) & $1,600 \mathrm{pCi} / \mathrm{g}$ & \\
\hline 23) & URANIUM 233 & $3.9 \mathrm{pCi} / \mathrm{g}$ & $2.3 \mathrm{pCi} / \mathrm{g}$ \\
\hline 24 & URANIUM 234 & & $3.9 \mathrm{pCi} / \mathrm{g}$ \\
\hline 25 & URANIUM 235 & $1.23 \mathrm{pCi} / \mathrm{g}$ & $0.1 \mathrm{pCi} / \mathrm{g}$ \\
\hline 26 & URANIUM 238 & $4.7 \mathrm{pCi} / \mathrm{g}$ & $3.2 \mathrm{pCi} / \mathrm{g}$ \\
\hline 27 & ZINC 65 & ND & $0.24 \mathrm{pCi} / \mathrm{g}$ \\
\hline 28 & ZIRCONIUM 95 & $0.56 \mathrm{pCi} / \mathrm{g}$ & \\
\hline & Chemicals & & \\
\hline 29 & ACENAPHTHENE & $210 \mu \mathrm{g} / \mathrm{kg}$ (d) & \\
\hline 30 & ALUMINUM & $26,700,000 \mu \mathrm{g} / \mathrm{kg}$ & $9,350,000 \mu \mathrm{gg} / \mathrm{kg}$ \\
\hline 31. & AMMONIA & $12,800 \mu \mathrm{g} / \mathrm{kg}$ & $12,000 \mu \mathrm{g} / \mathrm{kg}$ \\
\hline 32 & ANTHRACENE & $430 \mu \mathrm{g} / \mathrm{kg}$ & \\
\hline 33 & AFOCLOR 1248 (PCB) & $9,900 \mu \mathrm{g} / \mathrm{kg}$ & \\
\hline 34 & ARSENIC & $47,000 \mu \mathrm{g} / \mathrm{kg}$ & $7,500 \mu \mathrm{g} / \mathrm{kg}$ \\
\hline $\begin{array}{r}-35 \\
\end{array}$ & BARIUM & $672,000 \mu \mathrm{g} / \mathrm{kg}$ & $120,000 \mu \mathrm{g} / \mathrm{kg}$ \\
\hline 36 & BENZENE & $4,500 \mu \mathrm{g} / \mathrm{kg}$ & \\
\hline 37 & BENZO(G,H,I)PERYLENE & $410 \mu \mathrm{g} / \mathrm{kg}$ & \\
\hline 38 & BENZOIa|ANTHRACENE & $940 \mu \mathrm{g} / \mathrm{kg}$ & \\
\hline 39 & BENZOIaIPYRENE & $810 \mu \mathrm{g} / \mathrm{kg}$ & \\
\hline 40 & BENZOAbIFLUORANTHENE & $890 \nu \mathrm{g} / \mathrm{kg}$ & \\
\hline 41. & BENZOIK]FLUORANTHENE & $760 \mu \mathrm{g} / \mathrm{kg}$ & \\
\hline 42. & BENZOIC ACID & $1,700 \mu \mathrm{g} / \mathrm{kg}$ & \\
\hline 43 & BERYLLIUM & $8,000 \mu g / k g$ & $1.100 \mu \mathrm{g} / \mathrm{kg}$ \\
\hline 44 & BIS(2-ETHYLHEXYL) PHTHALATE & $68,000 \mu \mathrm{g} / \mathrm{kg}$ & \\
\hline 45 & CADMIUM & $1,800 \mu \mathrm{g} / \mathrm{kg}$ & $2.700 \mu \mathrm{g} / \mathrm{kg}$ \\
\hline 46 & CALCIUM & $40,800,000 \mu \mathrm{g} / \mathrm{kg}$ & $4,460,000 \mu \mathrm{g} / \mathrm{kg}$ \\
\hline 47 & CHLORDANE & $4,500 \mu \mathrm{g} / \mathrm{kg}$ & \\
\hline 48 & CHLORIDE & $1,100 \mu \mathrm{g} / \mathrm{kg}$ & \\
\hline
\end{tabular}


Table 3.2. (contd)

\begin{tabular}{|c|c|c|c|}
\hline & \multirow[b]{2}{*}{ Name of Analyte } & \multicolumn{2}{|c|}{ Concentration in } \\
\hline & & Soil & Sediment \\
\hline 49 & CHLORINE (e) & & \\
\hline 50 & CHROMIUM & $259,000 \mathrm{rg} / \mathrm{kg}$ & $12,200 \mu \mathrm{g} / \mathrm{kg}$ \\
\hline 51 & CHRYSENE & $920 \mu \mathrm{g} / \mathrm{kg}$ & \\
\hline 52 & COBALT & $34,100 \mu \mathrm{g} / \mathrm{kg}$ & $11,500 \mu \mathrm{g} / \mathrm{kg}$ \\
\hline 53 & COPPER & $140,000,000 \mu \mathrm{g} / \mathrm{kg}$ & $40,000 y \mathrm{~g} / \mathrm{kg}$ \\
\hline 54 & CYANIDE. & $1,050 \mu \mathrm{g} / \mathrm{kg}$ & \\
\hline 55 & DIBENZOFURAN & $.130 \mu \mathrm{g} / \mathrm{kg}$ & \\
\hline 56 & DIESEL FUEL & $2,800,000 \mu \mathrm{g} / \mathrm{kg}$ & \\
\hline 57) & ENDRIN ALDEHYDE & $3.3 \mu \mathrm{g} / \mathrm{kg}$ & \\
\hline 58 & ETHYL BENZENE & $32,000 \mu \mathrm{g} / \mathrm{kg}$ & \\
\hline 59 & FLUORANTHENE & $1,800 \mu \mathrm{gg} / \mathrm{kg}$ & \\
\hline 60 & FLUORENE & $190 \mu \mathrm{gg} / \mathrm{kg}$ & \\
\hline 61 & FLUORIDE & $4,700 \mu \mathrm{g} / \mathrm{kg}$ & 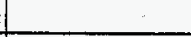 \\
\hline 62 & FLUORINE (e) & & \\
\hline 63 & INDENO(1,2,3-CD)PYRENE & $520 \mu \mathrm{g} / \mathrm{kg}$ & \\
\hline 64 & IRON & $33,500,000 \mu \mathrm{g} / \mathrm{kg}$ & $71,000,000 \mu \mathrm{g} / \mathrm{kg}$ \\
\hline 65 & KEROSENE & $3,085,000 \mu \mathrm{g} / \mathrm{kg}$ & \\
\hline 66 & LEAD & $540,000 \mu \mathrm{g} / \mathrm{kg}$ & $73,000 \mu \mathrm{g} / \mathrm{kg}$ \\
\hline 67 & LTTHUM (e) & & \\
\hline 68 & MAGNESIUM & $11,600,000 \mu \mathrm{g} / \mathrm{kg}$ & $7,600,000 \mu \mathrm{g} / \mathrm{kg}$ \\
\hline 69 & MANGANESE & $839,000 \mu \mathrm{g} / \mathrm{kg}$ & $579,000 \mu \mathrm{g} / \mathrm{kg}$ \\
\hline 70 & MERCURY & $4,300 \mu \mathrm{g} / \mathrm{kg}$ & \\
\hline 71 & METHYL-2-PENTANONE, 4 & $22,000 \mu \mathrm{g} / \mathrm{kg}$ & \\
\hline 72 & METHYLENE CHLORIDE & $120 \mu \mathrm{g} / \mathrm{kg}$ & \\
\hline 73 & METHYLNAPHTHALENE, 2- & $42 \mu \mathrm{g} / \mathrm{kg}$ & \\
\hline 74 & NICXEL & $221,000 \mu \mathrm{g} / \mathrm{kg}$ & $19.700 \mu \mathrm{g} / \mathrm{kg}$ \\
\hline 75 & NITRATE & $30,400 \mu \mathrm{g} / \mathrm{kg}$ & \\
\hline 76 & PHENANTHRENE & $1,500 \mu \mathrm{g} / \mathrm{kg}$ & \\
\hline 77 & POTASSIUM & $4,980,000 \mu \mathrm{g} / \mathrm{kg}$ & $1,900,000 \mu \mathrm{g} / \mathrm{kg}$ \\
\hline 78 & PYRENE & $1,200 \mu \mathrm{gg} / \mathrm{kg}$ & \\
\hline 79 & SELENIUM & $4,200 \mu \mathrm{rg} / \mathrm{kg}$ & \\
\hline 80 & SILVER & $1,900 \mu \mathrm{rg} / \mathrm{kg}$ & $2,500 \mu \mathrm{g} / \mathrm{kg}$ \\
\hline 81 & SILVER CHLORIDE & $17,300,000 \mu \mathrm{g} / \mathrm{kg}$ & \\
\hline 82 & SODIUM & $1,770,000 \mu \mathrm{g} / \mathrm{kg}$ & $920,000 \mu \mathrm{g} / \mathrm{kg}$ \\
\hline 83 & STRONTIUM & $67,000 \mu \mathrm{g} / \mathrm{kg}$ & \\
\hline 84 & STRONTIUM CHLORIDE & $1 \mu \mathrm{g} / \mathrm{kg}$ & \\
\hline 85 & SULFATE (SULFUR) & $131,000 \mu \mathrm{g} / \mathrm{kg}$ & \\
\hline 86 & TITANIUM (e) & & \\
\hline 87 & TOLUENE & $350,000 \mu \mathrm{gg} / \mathrm{kg}$ & \\
\hline 88 & TOTAL PETROLEUM HYOROCARBON & $1.26 E+08$ & \\
\hline 89 & VANADIUM & $389,000 \mu \mathrm{g} / \mathrm{kg}$ & $82,200 \mu \mathrm{g} / \mathrm{kg}$ \\
\hline 90 & XYLENE & $1,800,000 \mu \mathrm{rg} / \mathrm{kg}$ & \\
\hline 91 & ZINC & $309,000 \mu \mathrm{g} / \mathrm{kg}$ & $397,000 \mu \mathrm{g} / \mathrm{kg}$ \\
\hline 92 & ZIRCONIUM (e) & & \\
\hline (a) & $\mathrm{oCi} / \mathrm{g}=$ picocuries per gram. & & \\
\hline (b) & w/Pu239 = concentration included in & that reported for plutc & tonium-239. \\
\hline (c) & ND $=$ not detected. & & \\
\hline (d) & $\mu \mathrm{g} / \mathrm{kg}=$ micrograms per kilogram. & & \\
\hline (e) & Concentrations of these chemicals fail & within & \\
\hline & their respectively occurring backgroun & ievels. & \\
\hline
\end{tabular}


Table 3.3. Maximum Detected Concentrations in Groundwater in the Hanford Site 100, 200, and 600 Areas Away from the Columbia River, 1980-1994

\begin{tabular}{|c|c|c|}
\hline 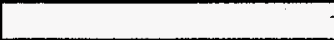 & Number & \\
\hline Name of Analyte & of Plumes & Concentration \\
\hline \multicolumn{3}{|l|}{100 Areas } \\
\hline Chromium $(+6)$ & 3 & $1,570 \mathrm{ppb}$ \\
\hline Nitrate & 10 & $130,000 \mathrm{ppb}$ \\
\hline Strontium-90 & 8 & $1,800 \mathrm{pCi} / \mathrm{L}$ \\
\hline Tritium (Hydrogen-3) & 4 & $80,000 \mathrm{pCi} / \mathrm{L}$ \\
\hline \multicolumn{3}{|l|}{200 West Area } \\
\hline Arsenic & 4 & $24 \mathrm{ppb}$ \\
\hline Carbon Tetrachloride & 1 & $6,559 \mathrm{ppb}$ \\
\hline Chloroform & 2 & $1,595 \mathrm{ppb}$ \\
\hline Chromium & 5 & $323 \mathrm{ppb}$ \\
\hline Fluoride & 3 & $10,067 \mathrm{ppb}$ \\
\hline lodine-129 & 2 & $30 \mathrm{pCi} / \mathrm{L}$ \\
\hline Nitrate & 5 & $1,322,000 \mathrm{ppb}$ \\
\hline Technetium-99 & 5 & $26,602 \mathrm{pCi} / \mathrm{L}$ \\
\hline Trichloroethylene & 3 & $32 \mathrm{ppb}$ \\
\hline Tritium (Hydrogen-3) & 3 & $6,193,000 \mathrm{pCi} / \mathrm{L}$ \\
\hline Uranium & 4 & $1,616 \mathrm{pCi} / \mathrm{L}$ \\
\hline \multicolumn{3}{|l|}{200 East Area } \\
\hline Arsenic & 4 & $24 p p b$ \\
\hline Cesium-137 & 1 & $1,326 \mathrm{pCi} / \mathrm{L}$ \\
\hline Chloroform & 1 & $7 \mathrm{ppb}$ \\
\hline Chromium & 4 & $288 \mathrm{ppb}$ \\
\hline Cobalt- 60 & 2 & $440 \mathrm{pCi} / \mathrm{L}$ \\
\hline Cyanide & 2 & $893 \mathrm{ppb}$ \\
\hline lodine-129 & 3 & $20 \mathrm{pCi} / \mathrm{L}$ \\
\hline Nitrate & 7 & $397,000 \mathrm{ppb}$ \\
\hline Plutonium-239/240 & 1. & $69 \mathrm{pCi} / \mathrm{L}$ \\
\hline Strontium-90 & 5 & $5,149 \mathrm{pCi} / \mathrm{L}$ \\
\hline Technetium-99 & 2 & $22,163 \mathrm{pCi} / \mathrm{L}$ \\
\hline Tritium (Hydrogen-3) & 5 & $4,126,000 \mathrm{pCi} / \mathrm{L}$ \\
\hline Uranium & 1 & $27 \mathrm{pCi} / \mathrm{L}$ \\
\hline \multicolumn{3}{|c|}{600 Area (Solid Waste Landfill Site) } \\
\hline Chloroform & 1 & $0.5 \mathrm{ppb}$ \\
\hline Dichloroethane, 1,1 - & 1 & $7 \mathrm{ppb}$ \\
\hline Tetrachloroethene & 1 & $12 \mathrm{ppb}$ \\
\hline Trichloroethane, $1,1,1$ - & 1 & $50 \mathrm{ppb}$ \\
\hline Trichloroethene & 1 & $7 \mathrm{ppb}$ \\
\hline \multicolumn{2}{|c|}{ (a) $\mathrm{pCi} / \mathrm{L}=$ picocuries per liter. } & \\
\hline \multicolumn{2}{|l|}{ (b) $\mathrm{ppb}=$ parts per billion. } & \\
\hline
\end{tabular}




\subsection{Screening Approach}

The review of the available data indicated that concentrations of various radionuclides, carcinogenic chemicals, and hazardous chemicals had been measured in Columbia River water (Columbia River, springs, and seeps), groundwater, river sediment, and near-river soil. A multi-stage screening process to prioritize these various contaminants in terms of human health risk and ecosystem risk was developed. Each stage of the process identifies contaminants of interest. The combined results of the entire screening process then compose the total list of contaminants of concern.

The conceptual model for human health risk is associated with a scenario of a dedicated river user. The reference screening exposure scenario involves a person who frequents the shores of the river, drinks 2 liters/day of untreated river water, consumes about 0.25 kilograms/day (100 kilograms/year) (CRITFC 1994) of freshwater fish, and has an incidental sediment ingestion rate of 10 milligrams/day (almost 4 grams/year). This conceptual model is an adaptation and expansion of the Hanford Site risk assessment methodology (DOE 1992e).

The conceptual models for ecosystem risk are simpler, relying on the EPA Ambient Water Quality Criteria (EPA 1992) and on a fraction of the concentrations that result in mortality for fish.

All analytes found in the reviewed literature, which related to the 100,300 , and 1100 Areas, regions along the banks of the Columbia River, or inland contaminant plumes, were compiled (see Appendix A). Initial screening eliminated the contaminants on the list that showed no detectable levels of activity or concentration. In addition, analytes which were present only in tank wastes and not in environmental media were eliminated from the study.

\subsection{Screening Equations}

The screening process operates on one portion of the available data at a time. Separate screenings are used for measurements in Columbia River water, groundwater, river sediment, and near-river soil. Within each of these divisions, further subdivisions address radionuclides, carcinogens, human toxins, and fish toxins. All of the screenings rely on river water concentration or a surrogate as a starting point. Procedures for estimating the surrogates are described below.

\subsubsection{Radionuclide Screening}

The screening is based on a scenario of exposure to a dedicated river user (see definition above). Internal risks are estimated using the EPA slope factor for ingestion (EPA 1994a). The EPA slope factor represents the lifetime excess total cancer risk per unit of intake. External exposure to contaminated sediment is addressed by assuming the parameters associated with the EPA slope factor for external exposure are appropriate (EPA 1994a).

A relationship between the concentration of the contaminant in the water and the concentration in the sediment is required. For the screening, this relationship is assumed to be described by a ratio of $1: 100,000$ (i.e., the concentration of the contaminant in the sediment is assumed to be 100,000 times 
higher than in the Columbia River waters). This assumption is based on review of the very limited number of samples for which both river water and sediment values were available, as well as on an empirical equation developed for radionuclides in the Columbia River incorporated in the GENII computer code (Napier et al. 1988, p. 4.82).

The screening equation for radionuclides is:

$$
\text { SCREEN }=\mathrm{C}_{\mathrm{w}}\left[\frac{100,000 * \mathrm{SS}}{1000}+(730+100 * \mathrm{BCF}+100,000 * 0.0036) * \mathrm{IS}\right]
$$

where $\mathrm{C}_{\mathrm{w}}=$ measured or surrogate water concentration, $\mathrm{pCi} / \mathrm{L}$

$100,000=$ sediment $/$ water ratio, $\mathrm{L} / \mathrm{kg}$

$\mathrm{SS}=$ radionuclide slope factor for external exposure, risk/year per $\mathrm{pCi} / \mathrm{g}$

$1000=$ unit conversion, $\mathrm{g} / \mathrm{kg}$

$730=$ water consumption of $2 \mathrm{~L} /$ day for 1 year

$100=$ fish consumption of $100 \mathrm{~kg} /$ year

$\mathrm{BCF}=$ bioconcentration factor for fish, $\mathrm{L} / \mathrm{kg}$

$0.0036=$ sediment consumption of $10 \mathrm{mg} /$ day, giving $3.6 \mathrm{~g} /$ year

$\mathrm{IS}=$ radionuclide slope factor for ingestion, risk/pCi.

Values resulting from this screening which approach or are greater than $10^{-6}$ imply radionuclides of potential concern.

\subsubsection{Carcinogenic Chemical Screening}

The conceptual exposure patterns for carcinogens in river water are the same as those for radionuclides; however, there is no factor for external exposure. Because the chemical cancer potency factors for oral exposure are in units of inverse milligram per kilogram per day, the consumption terms are put in daily, rather than annual, units (EPA 1994a).

$$
\operatorname{SCREEN}=\mathrm{C}_{\mathrm{w}}\left[2+0.27 * \mathrm{BCF}+100,000 * 1 \times 10^{-5}\right](0.001) \frac{\mathrm{CPF}}{70}
$$

$$
\text { where } \begin{aligned}
\mathrm{C}_{\mathrm{w}} & =\text { measured or surrogate water concentration, } \mu \mathrm{g} / \mathrm{L} \\
2 & =\text { water consumption of } 2 \mathrm{~L} / \text { day } \\
0.27 & =\text { consumption of } 100 \mathrm{~kg} / \text { year of fish, on a daily basis } 0.27 \mathrm{~kg} \\
\mathrm{BCF} & =\text { bioconcentration factor for fish, } \mathrm{L} / \mathrm{kg} \\
100,000 & =\text { sediment } / \text { water ratio, } \mathrm{L} / \mathrm{kg} \\
1 \times 10^{-5} & =\text { consumption of } 10 \mathrm{mg} / \mathrm{day} \text { of sediment, } \mathrm{kg} \\
0.001 & =\text { conversion factor, micrograms to milligrams } \\
\mathrm{CPF} & =\text { cancer potency factor, (mg/kg/day) }{ }^{-1} \\
70 & =\text { assumed weight of an adult, } 70 \mathrm{~kg} .
\end{aligned}
$$

Values resulting from this screening which approach or are greater than $10^{-6}$ imply chemicals of potential concern. 


\subsubsection{Toxic Chemical Screening}

For hazardous, but noncarcinogenic, chemicals, the ranking is based on a ratio of the estimated daily intake to the EPA chronic oral reference dose (EPA 1994a). The conceptual scenario is the same as for the radionuclides or carcinogens.

$$
\text { SCREEN }=\mathrm{C}_{\mathrm{w}}\left[2+0.27 * \mathrm{BCF}+100,000 * 1 \times 10^{-5}\right] \frac{(0.001)}{70 * \mathrm{RfD}}
$$

$$
\text { where } \begin{aligned}
\mathrm{C}_{\mathrm{w}} & =\text { measured or surrogate water concentration, } \mu \mathrm{g} / \mathrm{L} \\
2 & =\text { water consumption of } 2 \mathrm{~L} / \text { day } \\
0.27 & =\text { consumption of } 100 \mathrm{~kg} / \text { year of fish, on a daily basis } 0.27 \mathrm{~kg} \\
\mathrm{BCF} & =\text { bioconcentration factor for fish, } \mathrm{L} / \mathrm{kg} \\
100,000 & =\text { sediment } / \text { water ratio, } \mathrm{L} / \mathrm{kg} \\
1 \times 10^{-5} & =\text { consumption of } 10 \mathrm{mg} / \text { day of sediment, } \mathrm{kg} \\
0.001 & =\text { conversion factor, micrograms to milligrams } \\
70 & =\text { assumed weight of an adult, } 70 \mathrm{~kg} \\
\mathrm{RfD} & =\mathrm{EPA} \text { chronic oral reference dose, } \mathrm{mg} / \mathrm{kg} / \text { day. }
\end{aligned}
$$

Values resulting from this screening which approach or are greater than unity imply chemicals of potential concern.

\subsubsection{Ambient Water Quality Criteria Screening}

For aquatic biota, the measured or surrogate concentration of the contaminant in water is compared with the applicable EPA water quality criterion (EPA 1992). The ambient water quality criteria are values of the concentrations of chemicals in water that are considered by the EPA to be protective of aquatic life. The screening equation is

$$
\text { SCREEN }=\frac{\mathrm{C}_{\mathrm{w}}}{\mathrm{AWQC}}
$$

where $\mathrm{C}_{\mathrm{w}}=$ measured or surrogate water concentration, $\mathrm{pCi} / \mathrm{L}$

AWQC $=$ ambient water quality criterion, $\mu \mathrm{g} / \mathrm{L}$.

Values resulting from this screening which approach or are greater than unity imply chemicals of potential concern.

\subsubsection{Aquatic Biota Toxicity Screening}

Limited data were available that identify the concentrations of certain chemicals that result in toxic effects to aquatic life. Where possible, the threshold concentration for fresh water at which any effect was noted was used. Although it would have been preferable to use information that related directly to the initiation of distress in aquatic life, rather than mortality, such information (e.g., the threshold limit value for the medium) was available for only a few chemicals. Therefore, the lowest concentration 
lethal to 50 percent of small, freshwater fish (e.g., guppies, mosquito fish, rainbow trout) tested was also used (EPA 1985). To relate these lethal effects to less significant effects, the screening used a value of 1 percent of the LC50 in the determination. For a few analytes for which fish data were not available, test results for crayfish or insects were used as a surrogate. The equation is

$$
\text { SCREEN }=\frac{C_{w}}{(L D 50 / 100)} \text { else } \frac{C_{w}}{T L M}
$$

where $\mathrm{C}_{\mathrm{w}}=$ measured or surrogate water concentration, $\mathrm{pCi} / \mathrm{L}$

LD50 = concentration of contaminant lethal to 50 percent of the tested fish population in time periods ranging from 48 to 96 hours $\left(\mathrm{LC}_{50}\right), \mu \mathrm{g} / \mathrm{L}$

$\mathrm{TLM}=$ threshold limit for fresh water (TLM), $\mu \mathrm{g} / \mathrm{L}$.

Values using this screening approach or values greater than unity imply chemicals of potential concern.

A concern has been raised that groundwater, filtering through gravel beds into the waters of the Columbia River, could directly impact fish eggs laid in the gravels without prior dilution by Columbia River water. Sources of data related to the impact of the listed contaminants on fish eggs were sought. Very few positive connections between research on fish egg survival and contaminant concentrations were found, making it impossible to screen directly on this concept.

\subsection{Estimation of Contaminant Concentrations in River Water}

All of the screening equations presented in the preceding section require an estimate of the contaminant's maximum measured concentration in river water. Only the direct river measurements provide this information. For the other media, an estimated, surrogate water concentration must be developed. Radionuclide concentrations compiled were generally given in units of picocuries/liter or picocuries/gram. Chemical concentrations were standardized to units of micrograms/liter or micrograms/kilogram. Therefore, separate conversions were developed for radionuclides and chemicals.

\subsubsection{Radionuclides}

Separate sets of assumptions were needed to prepare screening surrogates for concentrations in river water for measurements in groundwater, river sediment, and near-river soil.

\subsubsection{Groundwater}

Groundwater adjacent to the Columbia River can flow into the river, and Columbia River water can flow into the groundwater, depending on river flow. Therefore, concentrations of contaminants in groundwater near the river are difficult to predict, and concentrations measured near the shore differ from those measured further inland. Flow rates from groundwater to the Columbia vary from location to location; individual springs may have very low flow rates. An average groundwater discharge to the Columbia River of 3 cubic feet per second (cfs) was modeled by Kipp et al. (1976) for a 8.3-kilometer 
(5-mile) length of the river near the Hanford townsite. Raymond et al. (1976) and Cline et al. (1985) report an estimated discharge of $100 \mathrm{cfs}$ over the entire Hanford Reach. More recent research (Wuestner and Devary 1993) indicates that $100 \mathrm{cfs}$ is an upper bound. For conservatism (i.e., to provide an overestimate of the resulting concentration in the river), this upper value of $100 \mathrm{cfs}$ was adopted for the screening. In effect, this implies that the entire volume of groundwater that flows from beneath Hanford to the Columbia River is contaminated to the maximum level reported. Thus, the conversion used is

$$
\mathrm{C}^{\circ}{ }_{\mathrm{w}}=\mathrm{C}_{\mathrm{gw}} * \frac{100}{100,000}
$$

where $\mathrm{C}_{\mathrm{w}}^{0}=$ surrogate river water concentration used in the screening, $\mathrm{pCi} / \mathrm{L}$

$\mathrm{C}_{\mathrm{gw}}=$ measured groundwater concentration, $\mathrm{pCi} / \mathrm{L}$

$100=$ groundwater discharge rate, cfs

$100,000=$ approximate annual average flow rate of the Columbia River at Hanford, cfs.

\subsubsection{River Sediment .}

Sediment within the river is both a reservoir of contaminants and a source of contamination of the river water, as the material desorbs or resuspends into the water column. Accurate representation of this process requires detailed knowledge of the chemical interactions of the contaminant and the water. Information at this level of detail is not available for most of the contaminants considered. For consistency with the dose estimation assumptions, this relationship is assumed to be described by an equilibrium ratio of 1:100,000 (i.e., the concentration of the contaminant in the sediment is assumed to be 100,000 times higher than in the Columbia River water). The conversion used is then

$$
\mathrm{C}^{\mathrm{o}}{ }_{\mathrm{w}}=\frac{\mathrm{C}_{\mathrm{sed}} * 1000}{100,000}
$$

where $\mathrm{C}^{\circ}{ }_{\mathrm{w}}=$ surrogate river water concentration used in the screening, $\mathrm{pCi} / \mathrm{L}$

$\mathrm{C}_{\text {sed }}=$ sediment concentration, $\mathrm{pCi} / \mathrm{g}$

$1000=$ unit conversion, $\mathrm{g} / \mathrm{kg}$

$100,000=$ assumed concentration ratio, $\mathrm{L} / \mathrm{kg}$.

\subsubsection{Near-River Soil}

Contaminants in waste sites or other sites adjacent to the Columbia River may not pose a current hazard to down-river users of the river, but they may pose a threat of future contamination of the river. The possibility also exists that such sources may be contributing as-yet undetected contamination to the river. One of the goals of the Columbia River Comprehensive Impact Assessment is to tie Hanford cleanup activities to the potential for river contamination. In this spirit, contaminated soil near the river is included as a possible source of contaminants. Adequate consideration of these contaminants must include site-specific details about how they could be transported from their current locations into the groundwater and hence into the Columbia River. For the purpose of screening, all contaminants are assumed to be environmentally mobile and potentially soluble in groundwater (contrast this assumption to that used for contaminants in sediment, where they are assumed to be tightly bound). 
Based on this assumption, the surrogate groundwater contamination is assumed to have the same concentration of contaminants as the soil. The total area of industrial activity comprises approximately 6 percent of the Hanford Site (Dirkes et al. 1994, p. 5). Because it is unreasonable to assume that all of Hanford soil is contaminated to the maximum concentration reported, an effective area of 1 percent is assumed. The set of assumptions used to convert groundwater to river water concentrations is then also applied. The resulting equation for surrogate river water concentration resulting from soil is

$$
\mathrm{C}^{\circ}{ }_{\mathrm{w}}=\mathrm{C}_{\mathrm{soil}} * \frac{(1000 * 1 * 100 * 0.01)}{100,000}
$$

where $\mathrm{C}^{0}{ }_{w}=$ surrogate river water concentration used in the screening, $\mathrm{pCi} / \mathrm{L}$

$\mathrm{C}_{\text {soil }}=$ concentration in soil, $\mathrm{pCi} / \mathrm{g}$

$1000=$ unit conversion, $\mathrm{g} / \mathrm{kg}$

$1=$ assumption of soil/groundwater concentration equivalency, $\mathrm{kg} / \mathrm{L}$

$100=$ groundwater discharge rate, $\mathrm{cfs}$

$0.01=$ fraction of total area contaminated, dimensionless

$100,000=$ approximate annual average flow rate of the Columbia River at Hanford, cfs.

\subsubsection{Chemicals}

Conversions from measured values to surrogate river water concentrations are also required for carcinogenic and hazardous chemical contaminants. The assumptions are the same as for radionuclides; however, the measured units are generally in micrograms $/ \mathrm{kg}$, rather than $\mathrm{pCi} / \mathrm{g}$, and some conversions differ by factors of 1000 .

\subsubsection{Groundwater}

The conversion is numerically identical to that for radionuclides:

$$
\mathrm{C}^{0}{ }_{\mathrm{w}}=\mathrm{C}_{\mathrm{gw}} * \frac{100}{100,000}
$$

where $\mathrm{C}^{0}{ }_{w}=$ surrogate river water concentration used in the screening, $\mu \mathrm{g} / \mathrm{L}$

$\mathrm{C}_{\mathrm{gw}}=$ measured groundwater concentration, $\mu \mathrm{g} / \mathrm{L}$

$100=$ groundwater discharge rate, $\mathrm{cfs}$

$100,000=$ approximate annual average flow rate of the Columbia River at Hanford, cfs.

\subsubsection{River Sediment}

The conversion is similar to that for radionuclides with the $\mathrm{g} / \mathrm{kg}$ conversion removed:

$$
\mathrm{C}_{\mathrm{w}}^{0}=\frac{\mathrm{C}_{\mathrm{sed}}}{100,000}
$$


where $\mathrm{C}^{o}{ }_{\mathrm{w}}=$ surrogate river water concentration used in the screening, $\mu \mathrm{g} / \mathrm{L}$

$\mathrm{C}_{\mathrm{sed}}=$ sediment concentration, $\mu \mathrm{g} / \mathrm{kg}$

$100,000=$ assumed concentration ratio, $\mathrm{L} / \mathrm{kg}$.

\subsubsection{Near-River Soil}

The conversion is similar to that for radionuclides with the $\mathrm{g} / \mathrm{kg}$ conversion removed:

$$
\mathrm{C}^{\mathrm{o}}{ }_{\mathrm{w}}=\mathrm{C}_{\mathrm{soil}} * \frac{(1 * 100 * 0.01)}{100,000}
$$

where $\mathrm{C}_{w}^{o}=$ surrogate river water concentration used in the screening, $\mu \mathrm{g} / \mathrm{L}$

$\mathrm{C}_{\text {soil }}=$ concentration in soil, $\mathrm{pCi} / \mathrm{g}$

$1=$ assumption of soil/groundwater concentration equivalency, $\mathrm{kg} / \mathrm{L}$

$100=$ groundwater discharge rate, $\mathrm{cfs}$

$0.01=$ fraction of total area contaminated, dimensionless

$100,000=$ approximate annual average flow rate of the Columbia River at Hanford, cfs.

\subsection{Screening Results}

Application of the equations and assumptions defined above results in a series of complementary, but not necessarily intercomparable, screening values for each contaminant. The varying numbers of assumptions and associated varying degrees of conservatism require that each of the screenings be evaluated separately. The results of the combined screenings, however, then define the overall list of contaminants of interest. The complete list of radionuclides and chemicals entered into the project database is presented in Appendix A. The parameters used in the calculation are presented in Appendix B. The complete numerical results are presented in Appendix C. The overall results and interpretation of the screening are given here.

During the screening process, a few radionuclides and chemicals were identified as of potential interest, but not carried forward. Some items were measurements determined to be within the naturally occurring background levels of these materials. These materials included the radionuclides beryllium-7 and potassium-40 and the chemicals barium, bismuth, boron, chlorine, fluorine, lithium, silicon, silver, sulfide, titanium, vanadium, and zirconium. In addition, several materials were identified by the screening process that the EPA (EPA 1991; EPA 1989) considers nonhazardous under environmental conditions. These materials removed from further consideration included aluminum, calcium, iron, magnesium, potassium, and sodium.

\subsubsection{River Water Sample Screening}

Of the thousands of available environmental samples, relatively few show positive identification of contaminants directly in the waters of the Columbia River. A screening level was used to account for over 1) 95 percent of the carcinogenic risk for each result, above a cutoff of $10^{-6}$, or 2 ) a noncarcinogenic hazard ranking of greater than 0.1 . The individual screenings and the contaminants identified via each are listed in Table 4.1. 
Table 4.1. Contaminants of Potential Interest Identified via Screening of Columbia River Samples

\begin{tabular}{|c|c|c|c|c|}
\hline $\begin{array}{l}\text { Radionuclide } \\
\text { Screening }\end{array}$ & $\begin{array}{c}\text { Carcinogenic } \\
\text { Chemical } \\
\text { Screening }\end{array}$ & $\begin{array}{l}\text { Hazard Index } \\
\text { Screening }\end{array}$ & $\begin{array}{c}\text { Ambient Water } \\
\text { Quality Criteria } \\
\text { Screening }\end{array}$ & $\begin{array}{c}\text { Aquatic } \\
\text { Toxicant } \\
\text { Screening }\end{array}$ \\
\hline Cesium-134 & Arsenic & Arsenic & Copper $^{(a)}$ & Arsenic \\
\hline Cesium-137 & & Copper $^{(a)}$ & Nickel $^{(a)}$ & Copper $^{(\mathbf{a})}$ \\
\hline \multirow[t]{6}{*}{ Cobalt- 60} & & Manganese & Zinc & Nickel $^{(a)}$ \\
\hline & & Nickel $^{(a)}$ & & Nitrate \\
\hline & & Nitrate & & Xylene $^{(b)}$ \\
\hline & & Toluene $^{(\mathbf{b})}$ & & Zinc \\
\hline & & Xylene $^{(b)}$ & & \\
\hline & & Zinc & & \\
\hline $\begin{array}{l}\text { (a) See discuss } \\
\text { (b) See discuss }\end{array}$ & 4.4 on $s$ & $\begin{array}{l}\text { near limit of } \\
\text { samples. }\end{array}$ & & \\
\hline
\end{tabular}

The two isotopes of radiocesium, cesium-134 and cesium-137, are present in worldwide fallout. It is likely that these two contaminants are largely derived from non-Hanford sources. The Hanford Environmental Dose Reconstruction Project did not identify these two radionuclides as resulting from significant Hanford releases (Napier 1993).

Several contaminants are highlighted in Table 4.1 with footnotes. These indicate a potential problem with the screening result on the basis of source information. These difficulties are described in Section 4.4 .

\subsubsection{Groundwater Sample Screening}

A very large fraction of available Hanford-related environmental samples are of groundwater. Only those taken within about a kilometer of the river were used in compiling the database used for the screening. Even so, many positive samples were noted. Most of the samples were derived from investigations of the Hanford operating areas $(100,300)$, but many were from wells located near the river but far from the reactor, fuel fabrication, and research sites. Contaminants identified for investigation include several metals. The individual screenings and the contaminants identified via each are listed in Table 4.2 .

\subsubsection{River Sediment Sample Screening}

Because the Hanford Reach is a relatively fast-flowing portion of the river, there is actually little accumulation of sediment at Hanford. Accordingly, sediment samples represent a very small portion of the historical Hanford data. This is a clear area for future sampling work. Nevertheless, the sediment 
samples did provide sufficient information to apply the screening technique. The individual screenings and the contaminants identified via each are listed in Table 4.3. Like the river water screening, this process identified two isotopes of cesium, both of which are most likely associated with global fallout.

Table 4.2. Contaminants of Potential Interest Identified via Screening of Groundwater Near the Columbia River

\begin{tabular}{|l|l|l|l|l|}
\hline $\begin{array}{c}\text { Radionuclide } \\
\text { Screening }\end{array}$ & $\begin{array}{c}\text { Carcinogenic } \\
\text { Chemical } \\
\text { Screening }\end{array}$ & $\begin{array}{c}\text { Hazard Index } \\
\text { Screening }\end{array}$ & $\begin{array}{c}\text { Ambient Water } \\
\text { Quality Criteria } \\
\text { Screening }\end{array}$ & $\begin{array}{c}\text { Aquatic } \\
\text { Toxicant } \\
\text { Screening }\end{array}$ \\
\hline $\begin{array}{l}\text { Cobalt-60 } \\
\text { Strontium-90 }\end{array}$ & Chromium & Antimony & Chromium & Chromium \\
& & $\begin{array}{l}\text { Copper } \\
\text { Mercury }\end{array}$ & Merper \\
& & Nitrate/Nitrite \\
& & Zhosphate & & Zinc \\
\hline
\end{tabular}

Table 4.3. Contaminants of Potential Interest Identified via Screening of Columbia River Sediment Samples

\begin{tabular}{|l|l|l|l|l|}
\hline $\begin{array}{c}\text { Radionuclide } \\
\text { Screening }\end{array}$ & $\begin{array}{c}\text { Carcinogenic } \\
\text { Chemical } \\
\text { Screening }\end{array}$ & $\begin{array}{c}\text { Hazard Index } \\
\text { Screening }\end{array}$ & $\begin{array}{c}\text { Ambient Water } \\
\text { Quality Criteria } \\
\text { Screening }\end{array}$ & $\begin{array}{c}\text { Aquatic } \\
\text { Toxicant } \\
\text { Screening }\end{array}$ \\
\hline Cesium-134 & Chromium & Arsenic & Chromium & Chromium \\
Cesium-137 & & Copper & Lead & Zinc \\
Cobalt-60 & & Lead & & \\
Europium-152 & & Zinc & & \\
\hline
\end{tabular}

\subsubsection{Near-River Soil Sample Screening}

Contaminants measured in soil near the Columbia River are generally not an immediate hazard because they are currently in the soil and not subject to mass transport to the river, and subsequent human and biotic exposure. However, their existence is the primary reason for continuing cleanup of the Hanford operating areas, and it is useful to have a screening prioritization. It is also useful to direct future sampling efforts to determine if any of the contaminants most likely to cause problems are beginning to reach the river. Because of the nature of the contamination (generally solids in or associated with soil) and the nature of the activities carried out at Hanford over its history, these contaminants differ somewhat from those actually found in more mobile media (river water, groundwater, and 
sediment). Even so, it is informative to note the similarities in the list generated via the soil screening with those lists generated for the other media. The individual screenings and the contaminants identified via each are listed in Table 4.4.

Table 4.4. Contaminants of Potential Interest Identified via Screening of Soil Near the Columbia River

\begin{tabular}{|c|c|c|c|c|}
\hline $\begin{array}{l}\text { Radionuclide } \\
\text { Screening }\end{array}$ & $\begin{array}{l}\text { Carcinogenic } \\
\text { Chemical } \\
\text { Screening }\end{array}$ & $\begin{array}{l}\text { Hazard Index } \\
\text { Screening }\end{array}$ & $\begin{array}{c}\text { Ambient Water } \\
\text { Quality Criteria } \\
\text { Screening }\end{array}$ & $\begin{array}{c}\text { Aquatic } \\
\text { Toxicant } \\
\text { Screening }\end{array}$ \\
\hline Cesium-137 & $\begin{array}{l}\text { Arochlor } 1248 \\
\text { (PCB) }\end{array}$ & Arsenic & $\begin{array}{l}\text { Arochlor } 1248 \\
\text { (PCB) }\end{array}$ & Chlordane \\
\hline Cobalt -60 & Benzo(a)pyrene ${ }^{(a)}$ & Chlordane & Chlordane & Mercury \\
\hline Europium-152 & Chromium & Copper & Chromium & Zinc \\
\hline \multirow[t]{6}{*}{ Europium-154 } & $\begin{array}{l}\text { Indeno }(1,2,3-C D) \\
\text { pyrene }^{(a)}\end{array}$ & Lead & Copper & Diesel Fuel \\
\hline & & Mercury & Lead & \\
\hline & & Nitrate & Mercury & \\
\hline & & $\begin{array}{l}\text { Silver } \\
\text { Chloride }\end{array}$ & & \\
\hline & & Zinc & & \\
\hline & & Diesel Fuel & & \\
\hline
\end{tabular}

\subsection{Use of Suspect Measurements}

The majority of the measurements taken over the past 15 years were collected in accordance with modern quality assurance procedures (Dirkes et al. 1994). The data from the references used in this report are traceable and of high quality. All data recorded in the referenced studies were used in the development of the screening approach reported here.

During the evaluation of tens of thousands of media samples for hundreds of analytes over a period of many years, it is statistically expected that an occasional analysis will result in incorrect identification of an analyte or its quantity. The quality assurance procedures in place on the major Hanford Site databases generally serve to identify these abnormal values. For scientific completeness, the reported values are generally included in the databases with an indicator that they are potentially spurious. In the course of the evaluations for this report, six potential constituents of concern with single, questionable, measured results were encountered with the potential to influence the selection criteria, two in soil and four in Columbia River water. 
Two of the chemicals labeled with a footnote in Table 4.1 are toluene and xylene. These two chemicals were identified as coming from a single sample which may have been contaminated during sampling or analysis because these and other chemicals identified in that one sample are common laboratory and industrial solvents (Dirkes et al. 1993, p. 4.1). Since the suspect sample was paired with another suspect sample from upstream of Hanford, which also indicated high concentrations of organic contaminants, it is unlikely that these compounds are elevated in river water as a result of releases from Hanford.

Two other chemicals labeled with a footnote in Table 4.1 are copper and nickel. These two chemicals and several more identified in Table C.1 (see SW-LD notations) were very near the lower limits of detection in a series of samples at the Richland pumphouse (Dirkes et al. 1993). This reference compared concentrations of 20 volatile organic chemicals, 19 metals, and 7 anions upstream from Hanford (Vernita Bridge) and downstream (Richland). No volatile organic chemicals were routinely detected at either location. The concentrations of most metals were also very low. However, copper and nickel were each reported one time (out of nine sampling periods) as being slightly above the limit of detection. The limit of detection for copper for this study was 20 micrograms/liter. The single reported positive sample was 22 micrograms/liter. The limit of detection for nickel was 30 micrograms/liter. The single reported positive sample was 31 micrograms/liter. These values probably do not represent the actual level of river contamination.

Two chemicals labeled with a footnote in Table 4.4 are benzo(a)pyrene and indeno(1,2,3-CD) pyrene. Both of these chemicals appear only once in the database of samples, and both are analytes from the same physical sample. This one sample is noted in the historical record as being "suspect" because the analysis results for all contaminants evaluated were very high and not repeated in other nearby samples. It is likely that these two chemicals do not need to be on the master list for further evaluation. 


\subsection{Discrete Radioactive Particles}

The presence of small, discrete particles of radioactive material was discovered by Sula during a shoreline survey in 1978-1979 (Sula 1980). In the 1978-1979 survey, Sula reported finding 188 discrete particles of contaminated material. The majority of the discrete particles were found buried in rocky, flat areas with little or no vegetation. Sula recovered 14 particles for special study. Laboratory analysis identified the gamma radiations emitted from the particles to be entirely due to cobalt- 60 , with activities ranging from 1.7 to 24 microcuries. Sula $(1980$, p. 36$)$ describes the particles as

When isolated, the particles were barely visible to the naked eye, appearing as small, dark colored chips or flakes of roughly equal size. Microscopic examination of three particles showed them to be metallic appearing flakes with diameters of approximately $0.1 \mathrm{~mm}$. The particles were found to vary in elemental composition, but all contained significant proportions of chromium, iron, and cobalt characteristic of the alloy stellite, used in valve and pump components in all of the production reactors.

Sula declined to predict how many particles exist in the Columbia River but did note that "the number of particles found per square meter of ground surveyed decreases as one travels downstream from the reactor areas" (Sula 1980, p. 36).

The next attempt to measure these particles came in 1993 (Cooper and Woodruff 1993). Although the area surveyed was somewhat less than that surveyed by Sula, the 1993 survey also found 11 particles: 10 on one island near the reactors and one further downstream. Two particles were recovered for further analysis. The activities of these two particles were 1.7 and 16 microcuries of cobalt-60.

Most recently, cleanup efforts have been initiated on the island closest to and downstream of the 100-D Area, the island noted in both the Sula and Cooper and Woodruff surveys as having the highest concentration of particles. To date, 103 particles have been recovered, with activities ranging from 0.13 to 22 microcuries of cobalt-60, and minor amounts of other Hanford radionuclides (Wade and Wendling 1994).

Cooper and Woodruff (1993) included an evaluation of the potential for radiation dose from inhalation or ingestion of a discrete particle and from external exposure. It is concluded that, although the possibility of inhalation is remote, the dose-limiting exposure pathway is the inhalation of a particle at the upper end of the range of activity that would remain lodged in the nasal passages for up to 48 hours, resulting in a dose about 10 times the limit for occupational exposure (NCRP 1989). 


\subsection{Direct Irradiation from Hanford Facilities}

For the last several years, the highest direct radiation exposure rates from Hanford operations observed at locations where the public currently has access have been on the Columbia River along the shoreline at the 100-N Area (e.g., Dirkes et al. 1994). Thermoluminescent dosimeter measurements have been reported annually in the Hanford Site annual environmental reports for this location since 1990. The source of the elevated exposure rates is radiation from facilities located above the river in the 100-N Area. The shoreline is not currently accessible to the public, but the adjacent river is open to the public for recreational uses.

Elevated dose rates at the shoreline are reported in Dirkes et al. (1994, pp. 76, 168). The highest values were measured adjacent to the $\mathrm{N}$ Reactor itself and also near the 1301-N Liquid Waste Disposal Facility. The highest readings along the shoreline in 1994 ranged up to about 100 microroentgen/hour in an area where background exposure rates are in the range of 7-10 microroentgen/hour. Dirkes et al. $(1994$, p. 75$)$ qualify this number to be a probable overestimate. The dose rates have fallen significantly since the closure of the $\mathrm{N}$ Reactor in 1988. Dose rates are also elevated near the 100-K Area because of radiologically contaminated materials such as internally contaminated ion-exchange modules used in maintaining water quality in the nearby $105-\mathrm{KE}$ fuel storage basin. A third area of elevated exposure rates is adjacent to the 300 Area.

In 1993, measurements were also made by boat on the Columbia River adjacent to the $N$ Reactor facilities, about 75 meters (250 feet) from the Hanford shoreline (Cooper and Woodruff 1993, p. 4.12-4.13). At this distance, the exposure rates along a 1500-meter (5000-foot) track parallel to the facility ranged from essentially background levels ( 5 microroentgen/hour) to about 20 microroentgen/ hour. Exposure rates on the north shore of the river, across from $\mathrm{N}$ Reactor, were all essentially background.

In 1988, EG\&G performed an aerial survey of direct exposure rates on the Hanford Site, including the Columbia River and adjacent facilities (EG\&G 1990). A low-level, generalized increase in exposure rates is indicated for the shorelines of most of the river. The individual facilities are distinctly noticeable. The 100-N Area evidences the highest exposure rates of river locations. 


\subsection{Potential Future Groundwater Sources}

Certain contaminants now in soil or groundwater distant from the Columbia River at Hanford may some time in the future pose a source of contamination to the river. Some distant contaminants are essentially certain to reach the river, and others are, at this time, only potential, in part because planned remedial actions will either immobilize or remove them. The contaminants that are already in groundwater are quite likely to reach the Columbia River in the future. Those contaminants contained in Hanford tank farms or burial grounds may not pose a future hazard. For the Columbia River Comprehensive Impact Assessment, only those currently in the groundwater as defined in Section 7.1 are considered. Brief reference is given in Section 7.2 to documentation of the other categories of materials.

\subsection{Existing Groundwater Plumes}

More than 105 plumes, containing 20 contaminants, are readily observable in groundwater beneath the Hanford Site (Ford 1993; DOE 1994b). A summary of the nature of the existing groundwater contaminant plumes, their general locations, and maximum measured concentrations is given in Table 3.3. Maps of these plumes are provided in Ford (1993), DOE (1994b), and Dirkes et al. (1994). (Note that each of the authors of these reports draws the outlines of the plumes somewhat differently, depending on the purpose of the reports.) An example of one of the most widely dispersed contaminants, nitrate, is shown in Figure 7.1 (Dirkes et al. 1994).

Because those existing contaminant plumes addressed in this section of the report are not in direct contact with the Columbia River, they do not yet constitute a source of contaminants in the river. The window for future concern varies depending both on the location of the plumes and the material in them. Groundwater travel times from the current location to discharge in the river vary by location. Travel times in the 100 Areas generally are less than 1 year. Travel times for groundwater carrying the plumes in the 200 East Area are generally in the range of 20 to 200 years. Travel times for the contaminants in the 600 Area evolving from the Central Landfill Site (see Figure 7.1) are probably about 10 years. Travel times for plumes in the 200-West Area may be as long as 80 to 300 years (Freshley and Graham 1988). All of these estimated times depend on future groundwater conditions and influences such as quantity of water discharged from Hanford operating facilities.

Most of the contaminants listed in Table 3.1 are relatively mobile in groundwater. However, cobalt- 60 , strontium- 90 , and cesium- 137 have significant chemical interactions with the soil and move much more slowly than the groundwater. (They exist in the groundwater in the 200 Areas because they were essentially injected there directly during waste disposal rather than arriving via percolation

from a.surface source.) The chemical interactions add to the delay that these materials will experience, particularly those in the distant 200 Areas, before the plumes begin to discharge to the Columbia River. Because the half-lives of cobalt-60 (5.3 years), strontium-90 (28.8 years), and cesium-137 (30.2 years) are relatively short compared to the travel time from the 200 Areas to the Columbia River, they will decay before ever reaching the river. The strontium- 90 in the 100 Areas will likely reach the river or continue to enter the river as is the case at the 100- $\mathrm{N}$ Area. 


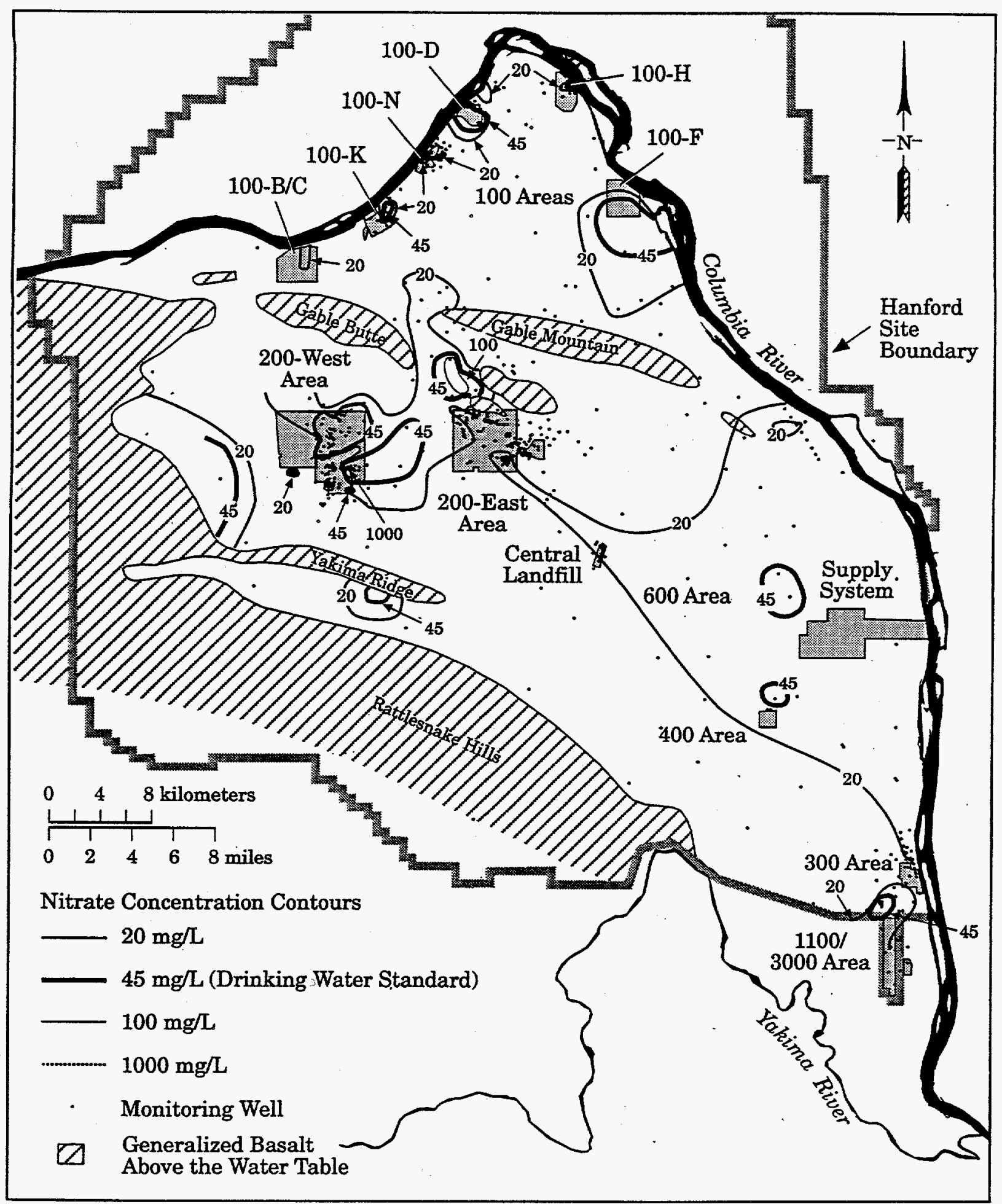

S9501004.3

Figure 7.1. Nitrate Plume 
Application of the equations and assumptions defined in Section 4.2 to the groundwater plumes results in a series of complementary, but not necessarily intercomparable, screening values for each contaminant. The varying numbers of assumptions and associated varying degrees of conservatism require that each of the screenings be evaluated separately. The combined results of the screenings, however, then define the overall list of contaminants of interest. The complete list of radionuclides and chemicals of concern entered into the project database is presented in Table 3.3. The parameters used in the calculations are presented in Appendix B. The complete numerical results are presented in Appendix C.

The overall screening results for existing groundwater plumes away from the river are given in Table 7.1.

Table 7.1. Contaminants of Potential Interest Identified via Screening of Groundwater Away from the Columbia River

\begin{tabular}{|c|c|c|c|c|}
\hline $\begin{array}{l}\text { Radionuclide } \\
\text { Screening }\end{array}$ & $\begin{array}{l}\text { Carcinogenic } \\
\text { Chemical } \\
\text { Screening }\end{array}$ & $\begin{array}{l}\text { Hazard Index } \\
\text { Screening }\end{array}$ & $\begin{array}{c}\text { Ambient Water } \\
\text { Quality Criteria } \\
\text { Screening }\end{array}$ & $\begin{array}{c}\text { Aquatic } \\
\text { Toxicant } \\
\text { Screening }\end{array}$ \\
\hline- & $\begin{array}{l}\text { Chromium } \\
\text { (100 Areas) }\end{array}$ & $\begin{array}{l}\text { Nitrate } \\
\text { (100 Areas) }\end{array}$ & - & $\begin{array}{l}\text { Chromium } \\
\text { (100 Areas) }\end{array}$ \\
\hline - & $\begin{array}{l}\text { Chromium } \\
\text { (200-West } \\
\text { Area) }\end{array}$ & $\begin{array}{l}\text { Nitrate } \\
\text { (200-West Area) }\end{array}$ & - & $\begin{array}{l}\text { Nitrate } \\
\text { (100 Areas) }\end{array}$ \\
\hline- & $\begin{array}{l}\text { Chromium } \\
\text { (200-East Area) }\end{array}$ & $\begin{array}{l}\text { Nitrate (200-East } \\
\text { Area) }\end{array}$ & - & $\begin{array}{l}\text { Fluoride } \\
\text { (200-West Area) }\end{array}$ \\
\hline - & - & $\begin{array}{l}\text { Carbon } \\
\text { Tetrachloride } \\
\text { (200-West Area) }\end{array}$ & - & $\begin{array}{l}\text { Nitrate } \\
\text { (200-West Area) }\end{array}$ \\
\hline - & - & - & - & $\begin{array}{l}\text { Nitrate (200-East } \\
\text { Area) }\end{array}$ \\
\hline
\end{tabular}

\subsection{Potential Future Groundwater Sources}

A very large number of radionuclides and chemicals are contained in Hanford facilities, waste management sites, or other contaminated areas. Remedial actions are planned or under way by the DOE under the provisions of the Hanford Federal Facility Agreement and Consent Order (Tri-Party Agreement) (Ecology et al. 1994) to bring the Hanford Site into compliance with the applicable requirements of CERCLA, RCRA, and the Washington State Hazardous Waste Management Act. The DOE program responsible for conducting remedial actions at the Hanford Site is referred to as the Richland Environmental Restoration Project. The scope of the Richland Environmental Restoration Project (DOE 1994h) encompasses the following groups of actions:

- radiation area remedial actions/underground storage tanks (UST)

- RCRA closures 
- single-shell tank (SST) closures

- past-practice site operable unit (source and groundwater) remedial actions

- surplus facilities decontamination and decommissioning

- storage and disposal facilities.

Radiation area remedial actions address the management and control of inactive waste sites to minimize the spread of surface soil contamination. The UST program addresses the management of state-regulated, nonradioactive USTs in accordance with Washington State regulations. RCRA closures address actions at certain waste management units classified under RCRA as treatment, storage, and disposal units (TSD). (At Hanford there are over 50 groups of TSD units.) Units subject to regulation as TSDs must either receive a RCRA operating permit or be closed in accordance with the RCRA closure process.

Single-shell tank closures address the development and implementation of final disposal of the 149 SSTs at Hanford. The Tank Waste Remediation System (TWRS) Environmental Impact Statement $(E I S)$ is addressing the management, treatment, storage, and disposal of waste in the SSTs. The Notice of Intent for the TWRS-EIS was published in the Federal Register on January 28, 1994 (59 FR 4052).

Past-practice operable unit remedial actions address the investigation and remediation of units where waste or other substances have been disposed (intentionally or unintentionally) and are not subject to regulation as TSDs. Over 1000 past-practice units have been identified at the Hanford Site (Ecology et al. 1994).

The Surplus Facilities Decontamination and Decommissioning Program addresses the safe management and final disposition of facilities, such as surplus production reactors and chemical processing buildings, that have been retired and declared surplus. Decontamination and decommissioning of the reactors along the Columbia River are addressed in the Decommissioning of Eight Surplus Production Reactors at the Hanford Site, Richland, Washington (Final Environmental Impact Statement) (DOE 1992c). Storage and disposal facilities address the planning, construction, and operation of facilities required for the success of the Richland Environmental Restoration Project (DOE 1994h). These facilities are being addressed individually through CERCLA, RCRA, and NEPA requirements.

Descriptions of the various potential impacts and releases to the Columbia River from the Richland Environmental Restoration Project (DOE 1994h) are provided in the Hanford Remedial Action Environmental Impact Statement (DOE 1994g). In addition to the Richland Environmental Restoration Project efforts (DOE 1994h), additional documentation on high-level waste and transuranic waste facilities is covered in the Final Environmental Impact Statement, Disposal of Hanford Defense High-Level, Transuranic, and Tank Wastes, Hanford Site, Richland, Washington (DOE 1987).

The future of the many existing waste sites is undergoing review. Very few will remain in their current condition. It is nearly impossible to predict the future impact of these sites until additional planning and activities occur. The reader is directed to the various references for further information on the potential contaminants and their potential future impact on the Columbia River. 


\subsection{Materials of Additional Public Interest}

As information has been released describing past operations and current conditions, public interest in the Hanford Site has increased. Some of the first questions raised during the public review of the Columbia River Impact Evaluation Plan (DOE 1993e) were about radiological contamination upriver from the Hanford Site. Questions were asked about the inclusion of chromium, nitrate, and sulfate ions, and the radionuclides cobalt-60 (dispersed as well as discrete particles), rubidium-86, molybdenum-96, ruthenium-106, cesium-137, europium-154, uranium and its decay progeny (specifically radium-226), and plutonium (from fuel failures as well as from decay of neptunium-239).

The majority of these topics have been addressed in this report. Background radiation is attributable to fallout from nuclear weapons testing or naturally occurring raclionuclides: potassium-40, radium, tritium (hydrogen-3), thorium, and uranium. In fact, at background levels, it is possible to calculate that nearly 90,000 kilograms (100 tons) of uranium from natural sources alone pass the Hanford Site in the Columbia River every year. The isotope rubidium-86 has an 18-day half-life, and any released from historical Hanford operations would have long ago decayed. Molybdenum- 96 is a stable isotope and, therefore, is not radioactive. The half-life of ruthenium-106 (367-day half-life) is similarly short. The half-lives of uranium isotopes are all in excess of 100,000 years (uranium-238, the progenitor of radium-226, has a half-life of 4.5 billion years), and no appreciable decay or progeny accumulation is expected to have occurred. During Hanford operations, about 6.3 million curies of neptunium-239 were released to the Columbia River (Heeb 1994, p. vii). All of that has now decayed into plutonium-239. Because each atom of neptunium becomes one atom of plutonium following the decay, there are no more atoms of plutonium in the river than there were neptunium atoms released. By ratio of the decay constants, that is shown to be no more than 1.7 curies of plutonium-239.

Extremely low levels of plutonium have been measured in the sediment behind McNary Dam, enriched by about 30 percent in plutonium-239 over what would be expected from background radiation derived from global fallout.

Public meetings were held in December 1993 and summer 1994 regarding the CRCIA efforts. At these meetings, questions were asked about tritium (hydrogen-3), iodine-129, and uranium. Each of these contaminants has been addressed in this report.

A report produced by a public interest group provides details on Hanford contamination by arsenic, carbon tetrachloride, chloroform, chromium, cyanide, iodine-129, nitrate, plutonium, strontium-90, technetium-99, trichloroethylene, tritium (hydrogen-3), and uranium (Columbia River United circa 1994). All of these contaminants have been addressed by the CRCIA Project and the results presented in this report (see Appendix A).

Iodine-129, plutonium, technetium-99, tritium (hydrogen-3), uranium, and volatile organic compounds (e.g., chloroform and trichloroethylene) are routinely analyzed in Columbia River water samples by the Surface Environmental Surveillance Project (SESP) and the concentrations and resulting exposures reported annually (e.g., Dirkes et al. 1994). Currently, radiation doses to maximally exposed off-site individuals via the river pathway are estimated to be $0.01 \mathrm{mrem} /$ year (Dirkes et al. 1994 , p. 220 ), corresponding to a maximum individual risk of approximately $10^{-8}$ per year (a probability of an additional fatal cancer of 1 in $100,000,000$ ). The concentrations of volatile organics are near or below detection levels. 
Of the contaminants of potential concern raised by the public, some are of concern, but several would have been eliminated by the screening process because they are shown to be of minimal potential hazard. However, those of continued public interest will continue to be evaluated in the CRCIA Project.

These contaminants of probable continued public interest are

- chloroform

- cyanide

- iodine-129

- plutonium-239/240

- technetium-99

- trichloroethylene

- tritium (hydrogen-3)

- uranium. 


\subsection{Conclusions}

More than 600 different radionuclides or chemicals have been sought in Hanford-related environmental samples. A large number of potential contaminants have never been detected in the Hanford/ Columbia River environments. For the roughly 100 compounds that have been detected at some level, screening on the basis of potential impact on human health or the health of Columbia River ecosystems has been performed. Several different types of screenings were employed. The results were consistent in that the same compounds were identified numerous times by the various screenings. Application of the screenings for contaminants within 150 meters ( 500 feet) of the Columbia River yields a list of 20 contaminants of concern, plus direct irradiation. These contaminants are given in the first column of Table 9.1 .

Existing Hanford groundwater contamination farther than 150 meters (500 feet) away from the Columbia River has also been addressed. The contaminants identified by the screening process (second column of Table 9.1) are not yet entering the Columbia River but have the potential to do so within 10 to 200 years (Freshley and Graham 1988). Two contaminants (chromium and nitrate) are common with those identified as being already in or near the river, and two (carbon tetrachloride and fluoride) are unique. Continued evaluation of the contaminants of concern (first column of Table 9.1) should cover most of the potential risk from the distant plumes.

Although the screenings did not indicate a potential risk, several potential or existing contaminants are of high interest to the public (third column in Table 9.1). Essentially all of these are the object of ongoing evaluation by SESP conducted by PNL at Hanford. The CRCIA Project should remain current on SESP activities and include SESP results in all project reports.

Each of the identified contaminants can be considered to have resulted from the past plutoniumproduction operations at Hanford. The radionuclides on the list generally represent those identified with river water or Hanford Reach sediment. The radionuclides resulted from activation of materials in the old production reactors. Although it is likely that the cesium isotopes are related to global fallout (Dirkes et al. 1994). Most of the metals identified in Hanford groundwater or sediment can be related to various Hanford operations in the 100 Areas. The PCB, Arochlor 1248, is used in equipment and the insecticide, Chlordane, has been used in Hanford facilities, but both are still essentially associated with soil near the river. The nitrate groundwater plumes result from past Hanford operations in the 100 and 200 Areas.

The reduction from more than 600 potential chemicals of concern to the final list of 20 , plus direct irradiation, was based on several complementary screening techniques and illustrates that future sampling and environmental analyses are both possible and tractable for the CRCIA Project. 
Table 9.1. List of Identified Contaminants of Concern ${ }^{(a)}$

\begin{tabular}{|c|c|c|}
\hline $\begin{array}{l}\text { In Columbia River, Ground- } \\
\text { water, }{ }^{(b)} \text { Sediment, and Soil }\end{array}$ & $\begin{array}{l}\text { Groundwater Plumes Away } \\
\text { from the Columbia River }{ }^{(c)}\end{array}$ & $\begin{array}{l}\text { Continued Public } \\
\text { Interest }\end{array}$ \\
\hline $\begin{array}{l}\text { Antimony } \\
\text { Arochlor } 1248 \text { (PCB) } \\
\text { Arsenic } \\
\text { Cesium-134 } \\
\text { Cesium-137 } \\
\text { Chlordane } \\
\text { Chromium }{ }^{(d)} \\
\text { Cobalt-60/particles } \\
\text { Copper } \\
\text { Diesel Fuel } \\
\text { Europium-152 } \\
\text { Europium-154 } \\
\text { Lead } \\
\text { Manganese } \\
\text { Mercury } \\
\text { Nitrate/nitrite } \\
\text { Phosphate } \\
\text { Silver Chloride } \\
\text { Strontium-90 } \\
\text { Zinc }\end{array}$ & $\begin{array}{l}\text { Carbon Tetrachloride } \\
\text { Fluoride }\end{array}$ & $\begin{array}{l}\text { Chloroform } \\
\text { Cyanide } \\
\text { Iodine-129 } \\
\text { Plutonium-239/240 } \\
\text { Technetium-99 } \\
\text { Trichloroethylene } \\
\text { Tritium (Hydrogen-3) } \\
\text { Uranium }\end{array}$ \\
\hline $\begin{array}{l}\text { (a) Direct irradiation is aiso identified as } \\
\text { (b) Hanford groundwater within } 150 \text { metete } \\
\text { (c) Hanford groundwater farther than } 150 \\
\text { (d) These contaminants are also of concer } \\
\text { list to avoid duplication. }\end{array}$ & $\begin{array}{l}\text { Ie Columbia River. } \\
\text { from the Columbia River. }\end{array}$ & er but are not repeated in that \\
\hline
\end{tabular}




\subsection{Perspective}

The identification of the radionuclides and chemicals of concern to the CRCIA Project should not imply that each or all of these compounds is necessarily a contamination or exposure problem for those who live downstream or the ecosystem of the Columbia River. The screening and selection process described in this report is a conservative (cautious) process designed to focus the resources of the project on those contaminants with potential risk.

Recent sampling has been performed in sediment of the Snake and Columbia Rivers as part of the studies underway concerning reservoir drawdowns for enhancement of salmon stocks. A study by Pinza et al. (1992) included grain size, total organic carbon, total volatile solids, ammonia, phosphorus, sulfides, oil and grease, total petroleum hydrocarbons, metals, polynuclear aromatic hydrocarbons, pesticides, PCBs, and 21 types of polychlorinated dibenzodioxins and dibenzofurans. Samples were taken from the Columbia River at the Port of Kennewick, the Boise Cascade facility below the confluence of the Snake and Columbia Rivers, and at Wallula Gap, as well as from 24 stations on the Snake River.

The study by Pinza et al. (1992) found most measured concentrations of all contaminants to be quite low in Columbia River sediment downstream of Hanford. The concentrations in this CRCIA Project report show most metals in Columbia River sediment to be within the ranges found by Pinza et al. (1992) in Snake River sediment. The few exceptions never differed from the extremes of the range found in the Snake River by more than a factor of 2 . One of the pesticides identified by the CRCIA Project as of potential concern, chlordane, was undetected by Pinza et al. (1992) in Columbia River sediment. The PCB, Arochlor 1248, identified by the CRCIA Project as of potential concern was also undetected by Pinza et al. (1992) in Columbia River sediment. The two polynuclear aromatic hydrocarbons discussed in Section 4.4 of this CRCIA report, benzo(a)pyrene and indeno(1,2,3-cd) pyrene, were undetected by Pinza et al. (1992) at Kennewick or Wallula Gap. The frequent inability to detect contaminants at the Boise Cascade facility make it impossible to make a comparison at that location. Petroleum products measured at Kennewick were the lowest found by Pinza et al. (1992) at any location.

Contaminants in the Columbia River, groundwater, sediment, and soil may have potential for impacts on human or ecological health in areas immediately adjacent to the Hanford shorelines, or throughout the Hanford Reach. However, it is evident from the results presented by Pinza et al. (1992) that Columbia River concentrations are similar to those in other rivers not associated with Hanford releases. Whereas Pinza et al. (1992) sampled for non-radionuclides, Wells (1994) examined data for radionuclides and concluded that the potential risk is lower than that allowed by the federal drinking water standards. 


\subsection{References}

59 FR 4052. January 28, 1994. "Intent to Prepare Hanford Tank Waste Remediation System Environmental Impact Statements, Richland, WA." Federal Register.

Ayres, J. M. 1993. Qualitative Risk Assessment for 100-HR-1 Source Operable Unit.

WHC-SD-EN-RA-004, Rev. 0, Westinghouse Hanford Company, Richland, Washington.

Beasley, T. M., L. A. Ball, J. E. Andrews III, and J. E. Halverson. 1981. "Hanford-Derived Plutonium in Columbia River Sediments." Science 214(4523):913-915.

Bisping, L. E. 1992. Hanford Site Environmental Data 1991-Surface and Columbia River. PNL-8149, Pacific Northwest Laboratory, Richland, Washington.

Bisping, L. E., and R. K. Woodruff. 1993. Hanford Site Environmental Data for Calendar Year 1992 - Surface and Columbia River. PNL-8683, Pacific Northwest Laboratory, Richland, Washington.

Bisping, L. E. 1994. Hanford Site Environmental Data for Calendar Year 1993 - Surface and Columbia River. PNL-9824, Pacific Northwest Laboratory, Richland, Washington.

Cline, C. S., J. T. Rieger, and J. R. Raymond. 1985. Ground-Water Monitoring at the Hanford Site, January - December 1984. PNL-5408, Pacific Northwest Laboratory, Richland, Washington.

Columbia River United. Circa 1994. Hanford and the River. Hood River, Oregon.

Cooper, A. T., and R. K. Woodruff. 1993. Investigation of Exposure Rates and Radionuclide and Trace Metal Distributions Along the Hanford Reach of the Columbia River. PNL-8789, Pacific Northwest Laboratory, Richland, Washington.

CRITFC - Columbia River Inter-Tribal Fish Commission. 1994. A Fish Consumption Survey of the Umatilla, Nez Perce, Yakama, and Warm Springs Tribes of the Columbia River Basin. CRITFC Technical Report No. 94-3, Portland, Oregon.

Dirkes, R. L. 1993. Columbia River Monitoring: Distribution of Tritium in Columbia River Water at the Richland Pumphouse. PNL-8531, Pacific Northwest Laboratory, Richland, Washington.

Dirkes, R. L. 1994. Summary of Radiological Monitoring of Columbia River Water along the Hanford Reach, 1980 through 1989. PNL-9223, Pacific Northwest Laboratory, Richland, Washington.

Dirkes, R. L., G. W. Patton, and B. L. Tiller. 1993. Columbia River Monitoring: Summary of Chemical Monitoring Along Cross Sections at Vernita Bridge and Richland. PNL-8654, Pacific Northwest Laboratory, Richland, Washington. 
Dirkes, R. L., R. W. Hanf, R. K. Woodruff, and R. E. Lundgren. 1994. Hanford Site Environmental Report for Calendar Year 1993. PNL-9823, Pacific Northwest Laboratory, Richland, Washington.

DOE - U.S. Department of Energy. 1987. Final Environmental Impact Statement, Disposal of Hanford Defense High-Level, Transuranic, and Tank Wastes, Hanford Site, Richland; Washington. DOE/EIS-0113, U.S. Department of Energy, Washington, D.C.

DOE - U.S. Department of Energy. 1989. Decommissioning of Eight Surplus Production Reactors at the Hanford Site, Richland, Washington, Draft Environmental Impact Statement. DOE/EIS-0119D, U.S. Department of Energy, Washington, D.C.

DOE - U.S. Department of Energy. 1990a. Remedial Investigation/Feasibility Study Work Plan for the 300-FF-5 Operable Unit, Hanford Site, Richland, Washington. DOE/RL 89-14, U.S. Department of Energy, Richland, Washington.

DOE - U.S. Department of Energy. 1990b. Remedial Investigation/Feasibility Study Work Plan for the 300-FF-1 Operable Unit, Hanford Site, Richland, Washington. DOE/RL 88-31, U.S. Department of Energy, Richland, Washington.

DOE - U.S. Department of Energy. 1990c. Low-level Burial Grounds Dangerous Waste Permit Application: Request for Exemption from Lined Trench Requirements for Submarine Reactor Compartments. DOE/RL-88-20, Supplement 1, U.S. Department of Energy, Richland, Washington.

DOE - U.S. Department of Energy. 1992a. Sampling and Analysis of 100 Area Springs. DOE/RL-92-12, Rev. 1, U.S. Department of Energy, Richland, Washington.

DOE - U.S. Department of Energy. 1992b. Hanford Site Groundwater Background. DOE/RL-92-23, U.S. Department of Energy, Richland, Washington.

DOE - U.S. Department of Energy. 1992c. Decommissioning of Eight Surplus Production Reactors at the Hanford Site, Richland, Washington (Final Environmental Impact Statement). DOE/EIS-0119F, U.S. Department of Energy, Washington, D.C.

DOE - U.S. Department of Energy. 1992d. Low-Level Burial Grounds Dangerous Waste Permit Application: Request for Exemption from Lined Trench Requirements and from Land Disposal Restrictions for Residual Liquid at 218-E-12B Burial Ground Trench 94. DOE/RL-88-20, Supplement 1, Revision 1, U.S. Department of Energy, Richland, Washington.

DOE - U.S. Department of Energy. 1992e. Hanford Site Baseline Risk Assessment Methodology, DOE/RL-91-45, Rev. 2., U.S. Department of Energy, Richland, Washington.

DOE - U.S. Department of Energy. 1993a. Limited Field Investigation Report for the 100-BC-5 Operable Unit. DOE/RL-93-37, Draft A, U.S. Department of Energy, Richland, Washington. 
DOE - U.S. Department of Energy. 1993b. Limited Field Investigation Report for the 100-DR-1 Operable Unit. DOE/RL-93-29, Draft A, U.S. Department of Energy, Richland, Washington.

DOE -.U.S. Department of Energy. 1993c. Limited Field Investigation Report for the 100-HR-1 Operable Unit. DOE/RL-93-51, Draft A, U.S. Department of Energy, Richland, Washington.

DOE - U.S. Department of Energy. 1993d. Limited Field Investigation Report for the 100-HR-3 Operable Unit. DOE/RL-93-43, Draft A, U.S. Department of Energy, Richland, Washington.

DOE - U.S. Department of Energy. 1993e. Columbia River Impact Evaluation Plan. DOE/RL-92-28, Rev. 0, U.S. Department of Energy, Richland, Washington.

DOE - U.S. Department of Energy. 1994a. Hanford Site Background: Part 1, Soil Background for Nonradioactive Analytes. DOE/RL-92-24, Rev. 2, Vol. 1 of 2. U.S. Department of Energy, Richland, Washington.

DOE - U.S. Department of Energy. 1994b. Annual Report for RCRA Groundwater Monitoring Projects at Hanford Site Facilities. DOE/RL-93-88, Rev. 0, U.S. Department of Energy, Richland, Washington.

DOE - U.S. Department of Energy. 1994c. HEIS - Hanford Environmental Information System. For documentation supporting the HEIS database, see DOE/RL-93-24, 9 volumes, U.S. Department of Energy, Richland, Washington. Queried: August 24, 1994.

DOE - U.S. Department of Energy. 1994d. Limited Field Investigation Report for the 100-BC-1 Operable Unit. DOE/RL-93-06, U.S. Department of Energy, Richland, Washington.

DOE - U.S. Department of Energy. 1994e. Limited Field Investigation Report for the 100-KR-1 Operable Unit. DOE/RL-93-78, Draft A, U.S. Department of Energy, Richland, Washington.

DOE - U.S. Department of Energy. 1994f. Limited Field Investigation Report for the 100-KR-4 Operable Unit. DOE/RL-93-79, U.S. Department of Energy, Richland, Washington.

DOE - U.S. Department of Energy. 1994g. Hanford Remedial Action Draft Environmental Impact Statement. DOE/DEIS-0222, U.S. Department of Energy, Washington, D.C.

DOE - U.S. Department of Energy. 1994h. Richland Environmental Restoration Project Plan. DOE/RL-92-08, U.S. Department of Energy, Richland, Washington.

Droppo, J. G., Jr., D. L. Strenge, J. W. Buck, B. L. Hoopes, R. D. Brockhaus, M. B. Walter, and G. Whelen. 1991. MEPAS ${ }^{T M}$ Multimedia Environmental Pollutant Assessment System, Application Guidance. PNWD-1857, Vol. 1, Battelle, Pacific Northwest Laboratories, Richland, Washington. 
Ecology - Washington State Department of Ecology, U.S. Environmental Protection Agency, and U.S. Department of Energy. 1994. Hanford Federal Facility Agreement and Consent Order.

Document No. 89-10, Rev. 3 (The Tri-Party Agreement), Washington State Department of Ecology, Olympia, Washington.

EG\&G Energy Measurements. 1990. An Aerial Radiological Survey of the Hanford Site and Surrounding Area, Richland, Washington. EGG-10617-1062, EG\&G Energy Measurements, The Remote Sensing Laboratory, Las Vegas, Nevada.

EPA - U.S. Environmental Protection Agency. 1985. OHM/TADS - Oil and Hazardous Materials/Technical Assistance Data System, in TOMES--Toxicology, Occupational Medicine, and Environmental Series (CD-ROM). Database used: Micromedex.

EPA - U.S. Environmental Protection Agency. 1989. Risk Assessment Guidance for Superfund; Human Health Evaluation Manual Part A. Interim Final, EPA/540/1-89/002, U.S. Environmental Protection Agency, Washington D.C.

EPA - U.S. Environmental Protection Agency. 1991. EPA Region 10 Supplemental Risk Assessment Guidance for Superfund. Published Draft. U.S. Environmental Protection Agency, Washington, D.C.

EPA - U.S. Environmental Protection Agency. 1992. Water Quality Standards; Establishment of Numeric Criteria for Priority Toxic Pollutants; States' Compliance; Final Rule (Federal Register). Vol. 57, No. 246. 12-22-92. U.S. Environmental Protection Agency, Washington, D.C.

EPA - U.S. Environmental Protection Agency. 1994a. Health Effects Assessment Summary Tables. FY-1994 Annual. EPA 540/R/94/020, U.S. Environmental Protection Agency, Washington, D.C.

EPA - U.S. Environmental Protection Agency. 1994b. IRIS - Integrated Risk Information System, in TOMES-Toxicology, Occupational Medicine, and Environmental Series (CD-ROM). Database used: Micromedex.

Eslinger, P. W., L. R. Huesties, A. D. Maughan, T. B. Miley, and W. H. Walters. 1994. Data Compendium for the Columbia River Impact Assessment. PNL-9785, Pacific Northwest Laboratory, Richland, Washington.

Ford, B. H. 1993. Groundwater Field Characterization Report for the 200 Aggregate Area Management Study. WHC-SD-EN-TI-020, Westinghouse Hanford Company, Richland, Washington.

Fowler, K. M., K. B. Miller, M. O. Hogan, and J. F. Donaghue. 1993. Risk-Based Standards Chemicals of Interest Database Documentation. Draft, prepared for the U.S. Department of Energy by Pacific Northwest Laboratory, Richland, Washington.

Freshley, M. D., and M. J. Graham. 1988. Estimation of Ground-Water Travel Time at the Hanford Site: Description, Past Work, and Future Needs. PNL-6328, Pacific Northwest Laboratory, Richland, Washington. 
Hartman, M. J., and K. A. Lindsey. 1993. Hydrogeology of the 100-N Area, Hanford Site, Washington. WHC-SD-EN-EV-027, Westinghouse Hanford Company, Richland, Washington.

Heeb, C. M., and D. J. Bates. 1994. Radionuclide Releases to the Columbia River from Hanford Operations, 1944-1971. PNWD-2223 HEDR, Battelle, Pacific Northwest Laboratories, Richland, Washington.

Jaquish, R. E. 1989. "Uranium-236 as an Indicator of Full-Cycle Uranium in Ground Water." Presented at the 35th Annual Conference on Bioassay, Analytical and Environmental Radiochemistry. PNL-SA-17410, Pacific Northwest Laboratory, Richland, Washington.

Kipp, K. L., A. E. Reisenauer, C. R. Cole, and C. A. Bryan. 1976. Variable Thickness Transient Groundwater Flow Model Theory and Numerical Implementation. BNWL-1703, Pacific Northwest Laboratory, Richland, Washington.

Law, A. G. 1990. Status of Groundwater in the 1100 Area. Correspondence Number 8900604B R4, Westinghouse Hanford Company, Richland, Washington.

Napier, B. A., R. A. Peloquin, D. L. Strenge, and J. V. Ramsdell. 1988. GENII - The Hanford Environmental Radiation Dosimetry Software System; Volume 1: Conceptual Representation. PNL-6584 Vol. 1, Pacific Northwest Laboratory, Richland, Washington.

Napier, B. A. 1993. Determination of Key Radionuclides and Parameters Related to Dose from the Columbia River Pathway. BN-SA-3768 HEDR, Battelle, Pacific Northwest Laboratories, Richland, Washington.

National Council on Radiation Protection and Measurements (NCRP). 1989. Limit for Exposure to "Hot Particles" on the Skin. NCRP Report No. 106, National Council on Radiation Protection and Measurements, Bethesda, Maryland.

Navy - U.S. Department of the Navy. 1984. Final Environmental Impact Statement on the Disposal of Decommissioned, Defueled Naval Submarine Reactor Plants. United States Department of the Navy, Washington, D.C.

NPS - National Parks Service. 1992. Hanford Reach of the Columbia River, Draft Comprehensive River Conservation Study and Environmental Impact Statement. U.S. Department of Interior, Seattle, Washington.

Peterson, R. E., and V. G. Johnson. 1992. Riverbank Seepage of Groundwater Along the 100 Areas Shoreline, Hanford Site. WHC-EP-0609, Westinghouse Hanford Company, Richland, Washington.

Pinza, M. R., J. Q. Word, E. S. Barrows, H. L. Mayhew, and D. R. Clark. 1992. Snake and Columbia Rivers Sediment Sampling Project. PNL-8479, Pacific Northwest Laboratory, Sequim, Washington. 
Raymond, J. R., D. A. Myers, J. J. Fix, V. L. McGhan, and P. M. Schrotke. 1976. Environmental Monitoring Report on Radiological Status of the Ground Water Beneath the Hanford Site, January December 1974. BNWL-1970, Pacific Northwest Laboratory, Richland, Washington.

Rhoads, K., B. N. Bjornstad, R. E. Lewis, S. S. Teel, K. J. Cantrell, R. J. Serne, J. L. Smoot, C. T. Kincaid, and S. K. Wurstner. 1992. Estimation of the Release and Migration of Lead Through Soils and Groundwater at the Hanford Site 218-E-12B Burial Ground. PNL-8356 Vol. 1., Pacific Northwest Laboratory, Richland, Washington.

Rhoads, K., B. N. Bjornstad, R. E. Lewis, S. S. Teel, K. J. Cantrell, R. J. Serne, L. H. Sawyer, J. L. Smoot, J. E. Szecsody, M. S. Wigmosta, and S. K. Wurstner. 1994. Estimation of the Release and Migration of Nickel Through Soils and Groundwater at the Hanford Site 218-E-12B Burial Ground. PNL-9791, Pacific Northwest Laboratory, Richland, Washington.

Rowley, C. A. 1993. 100-N Area Underground Storage Tank Closures. WHC-SD-EN-TI-136, Westinghouse Hanford Company, Richland, Washington.

Sula, M. J. 1980. Radiological Survey of Exposed Shorelines and Islands of the Columbia River Between Vernita and the Snake River Confluence. PNL-3127, Pacific Northwest Laboratory, Richland, Washington.

Wade, C. D., and M. A. Wendling. 1994. 100-D Island USRADS Radiological Surveys Preliminary Report Phase II. BHI-00-134, Bechtel Hanford, Inc., Richland, Washington.

Weiss, S. G. 1993. 100 Area Columbia River Sediment Sampling. WHC-SD-EN-TI-198, Rev. 0, Westinghouse Hanford Company, Richland, Washington.

Wells, D. 1994. Radioactivity in Columbia River Sediments and their Health Effects. Special Report, Washington State Department of Health, Olympia, Washington.

Woodruff, R. K., R. W. Hanf, and R. E. Lundgren. 1992. Hanford Site Environmental Report for Calendar Year 1991. PNL-8148, Pacific Northwest Laboratory, Richland, Washington.

Woodruff, R. K., R. W. Hanf, and R. E. Lundgren. 1993. Hanford Site Environmental Report for Calendar Year 1992. PNL-8682, Pacific Northwest Laboratory, Richland, Washington.

Wurstner, S. K., and J. L. Devary. 1993. Hanford Site Ground-Water Model: Geographical Information System Linkages and Model Enhancements, FY 1993. PNL-8991, Pacific Northwest Laboratory, Richland, Washington. 


\section{Appendix A}

Complete List of Analytes Evaluated at Hanford 


\section{Appendix A}

\section{Complete List of Analytes Evaluated at Hanford}

Table A.1 provides a complete listing of all radionuclides and chemicals for which monitoring has been reported in the reviewed literature of samples from the Columbia River and groundwater in the Hanford Site 100, 300, and 1100 Areas within 150 meters (500 feet) of the Columbia River. For those contaminants which had a detected level, the highest concentration reported is listed. A total of 568 analytes are listed. The 73 analytes for which detected levels were reported are listed in Table 3.1.

Table A. 2 provides a complete listing of all radionuclides and chemicals for which monitoring has been reported in the reviewed literature of samples from soil and sediment in the Hanford Site 100, 300 , and 1100 Areas. For those contaminants which had a detected level, the highest concentration reported is listed. A total of 560 analytes are listed. The 92 analytes for which detected levels were reported are listed in Table 3.2 .

Table A. 3 provides a listing of the major radionuclides and chemicals for which monitoring has been reported in the reviewed literature of samples from groundwater in the Hanford Site 100, 200, and 600 Areas farther than 150 meters (500 feet) away from the Columbia River. The listing is not comprehensive for all analytes, as described in Section 7.0.

The following abbreviations are used in the tables. All units are as reported in the reviewed literature. The column headings, such as $100-\mathrm{KR}-4$, refer to sampling locations at operable units, described in Section 2.0.

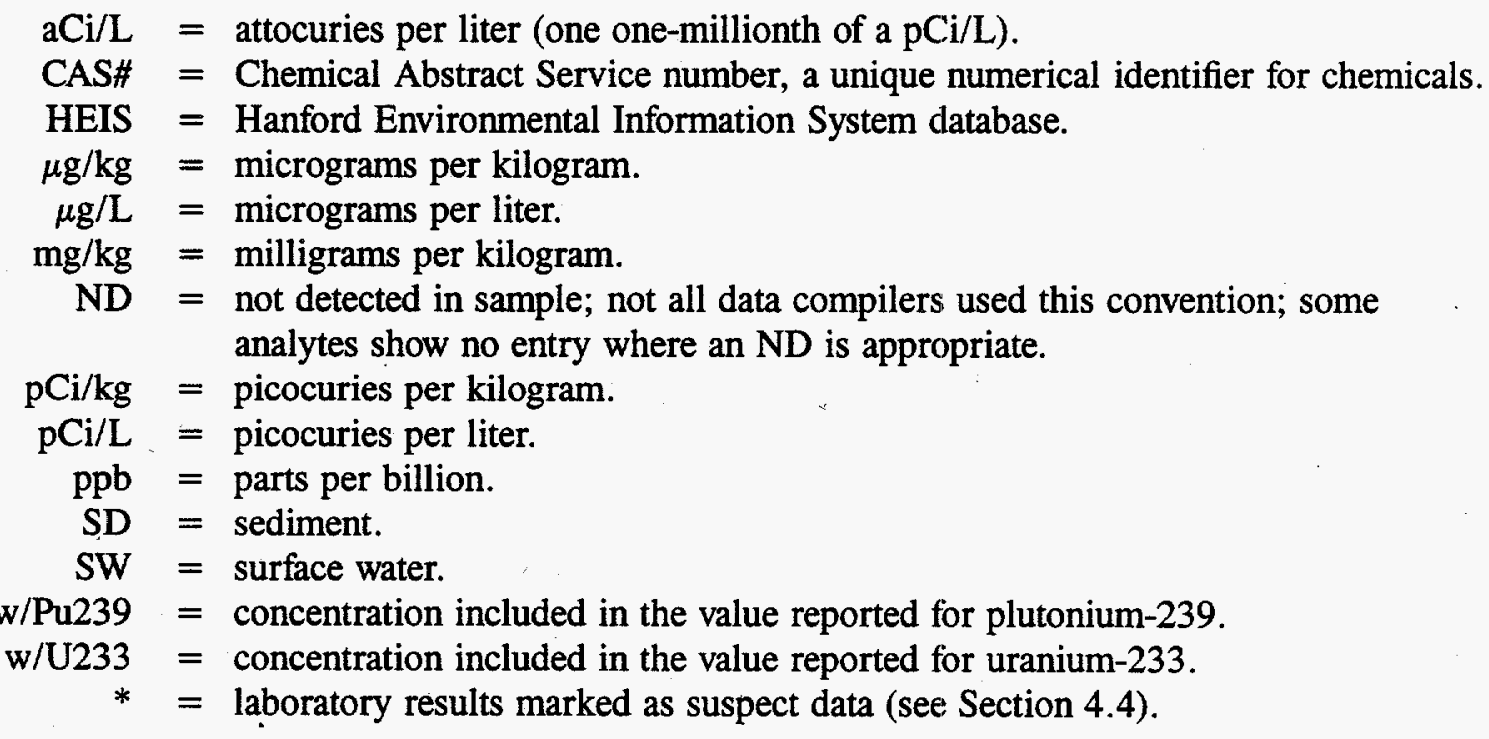




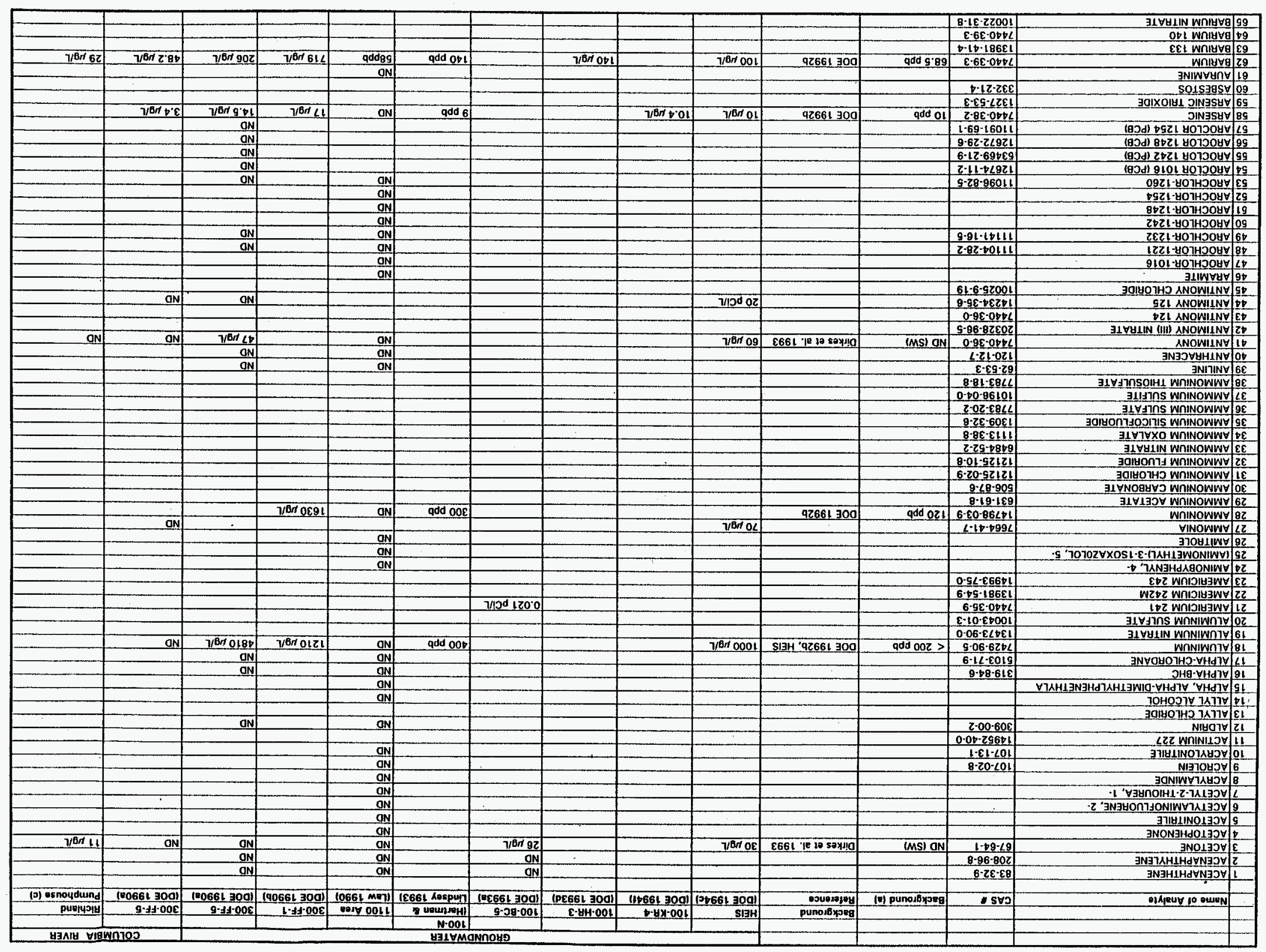

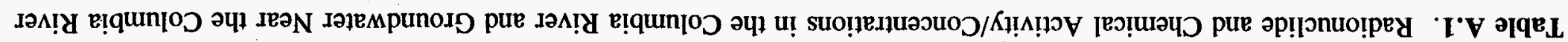


Table A.1. (contd)

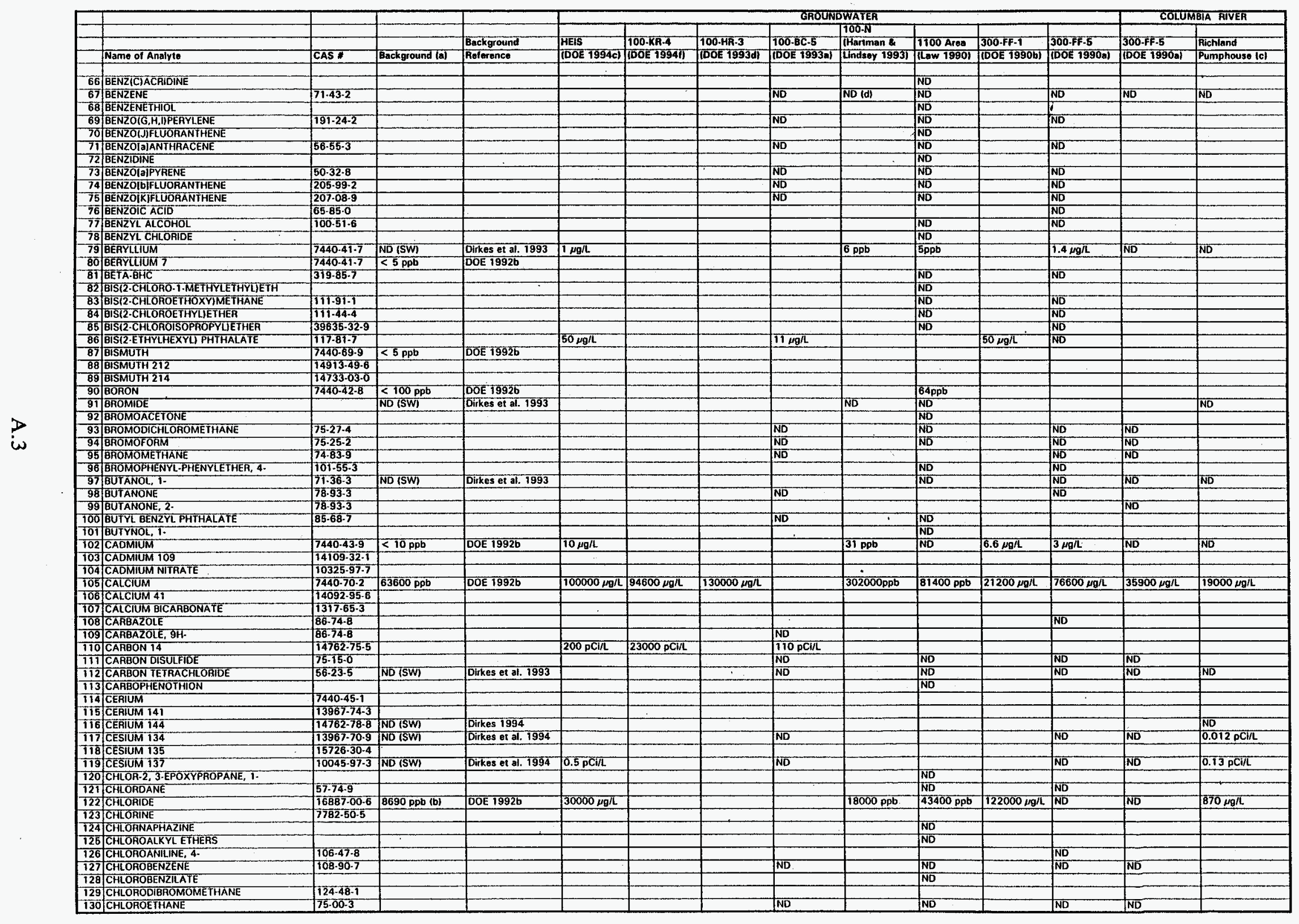




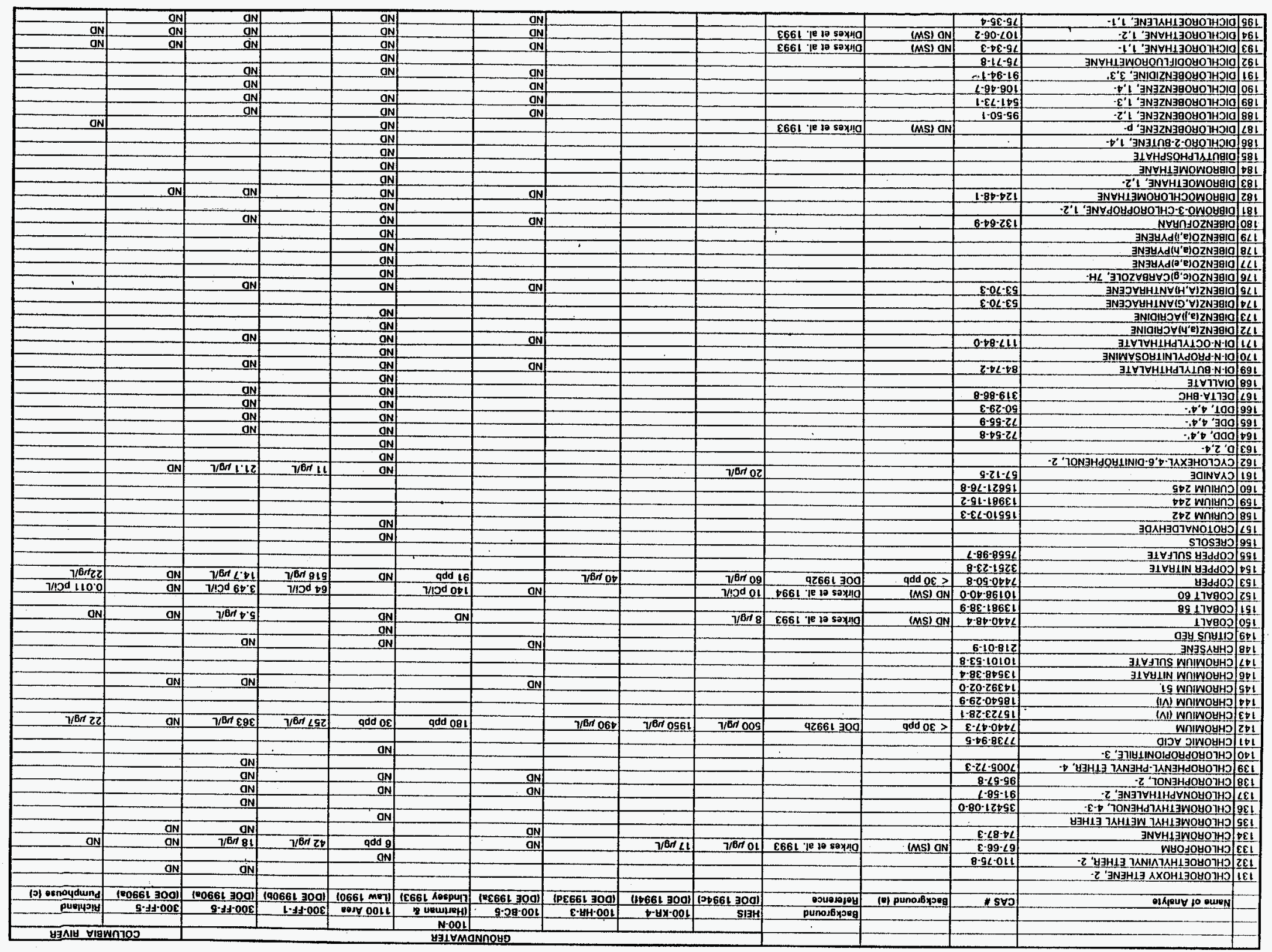

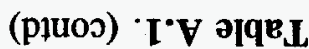




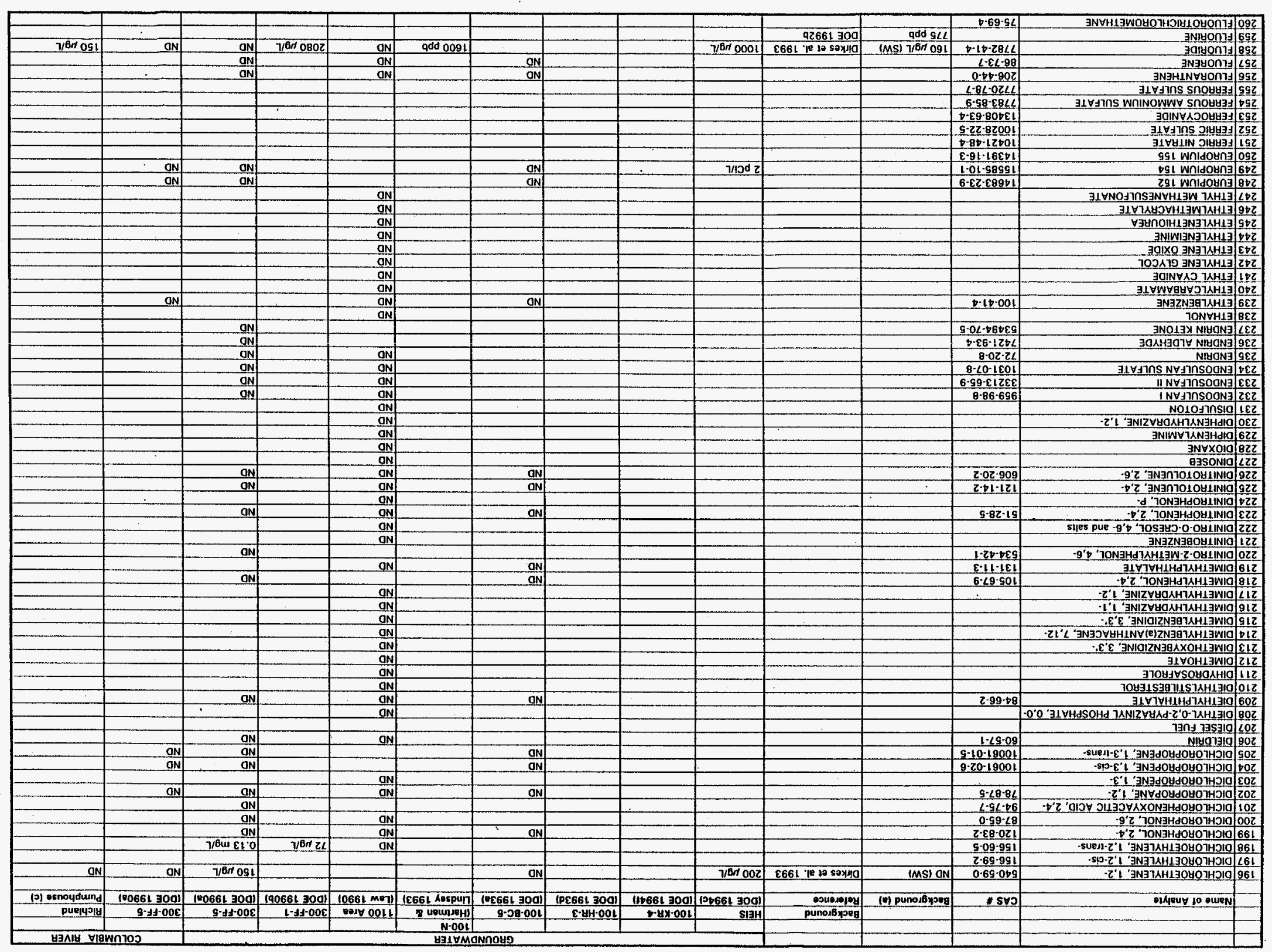


Table A.1. (contd)

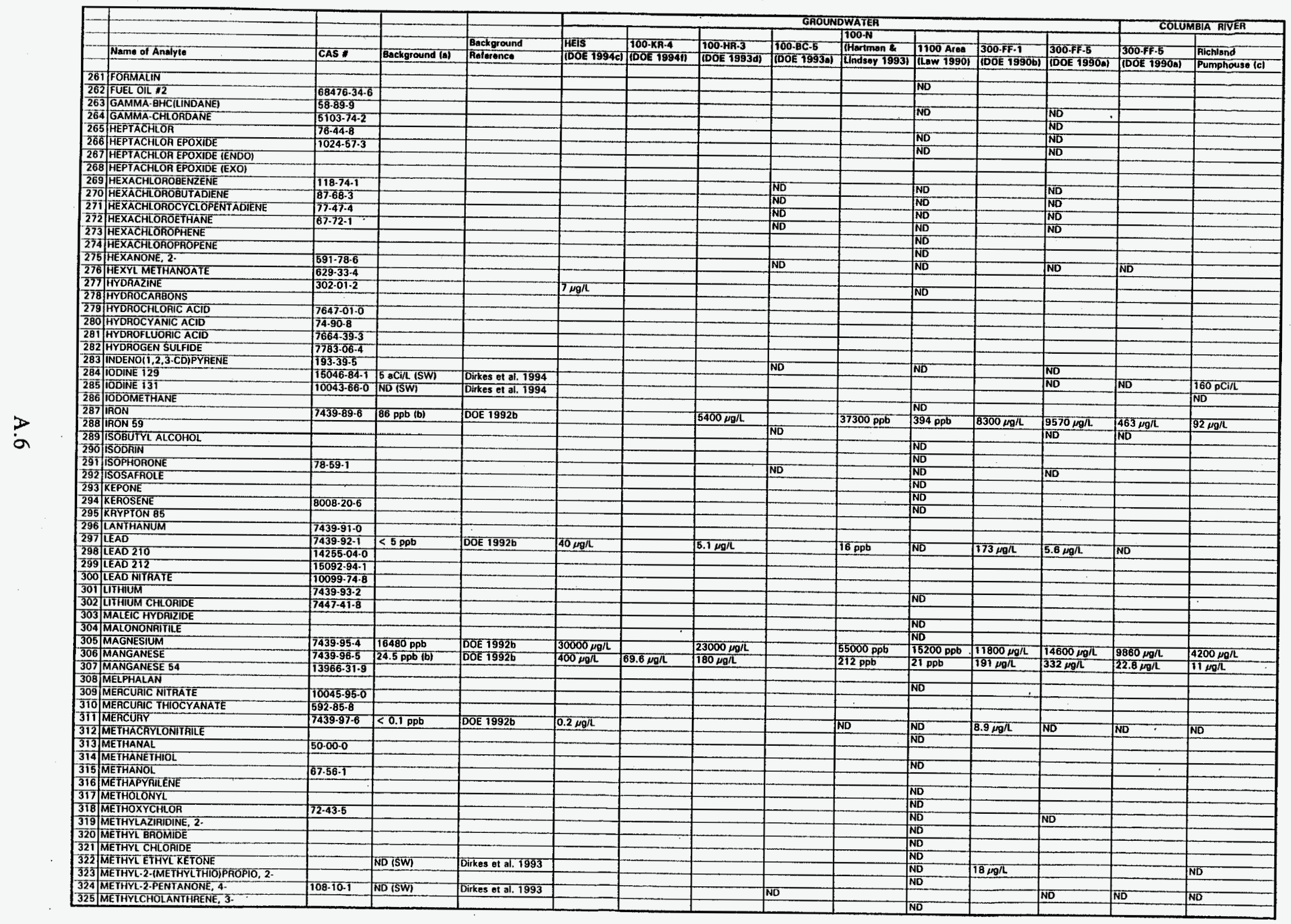




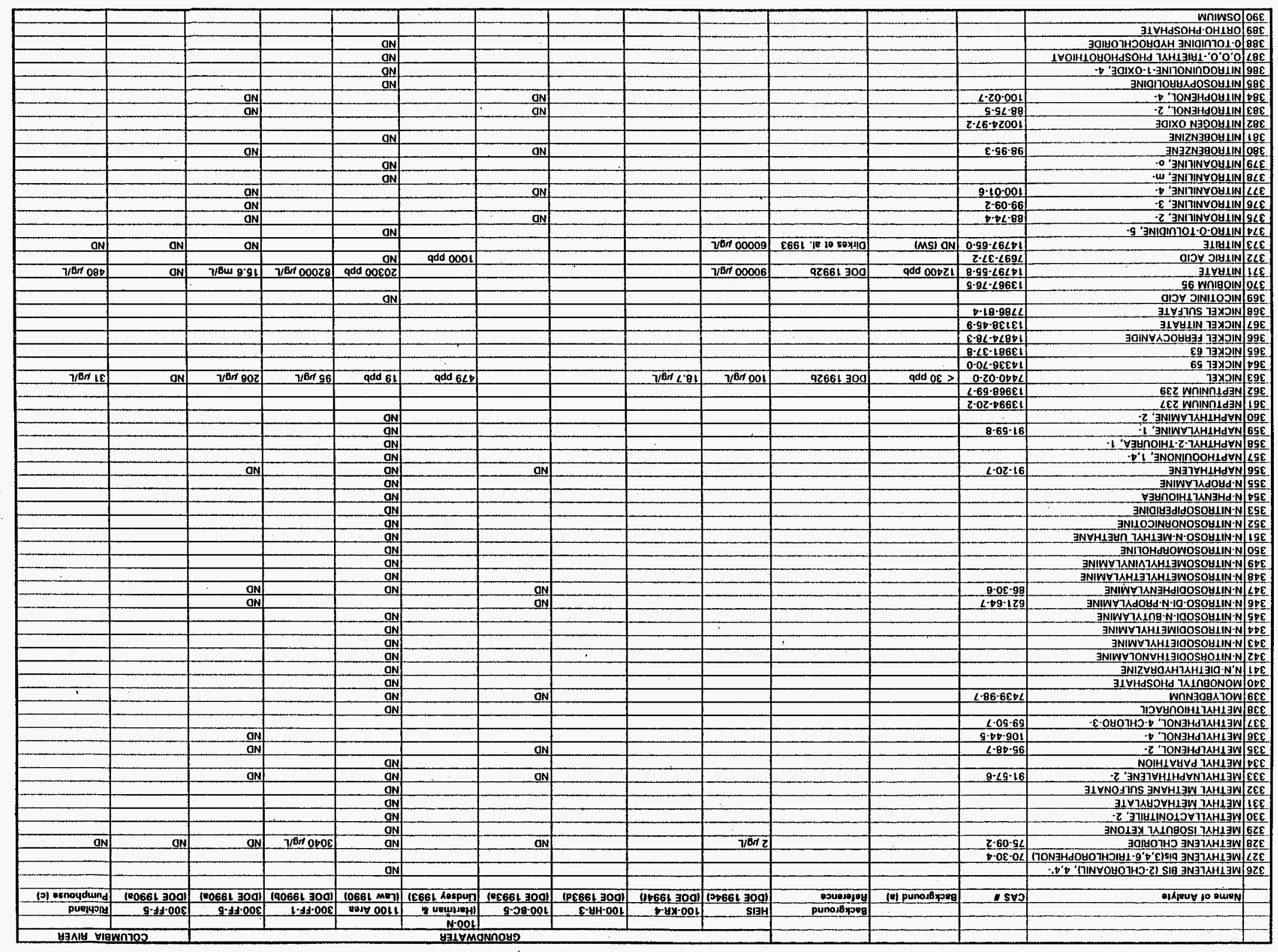


Table A.1. (contd)

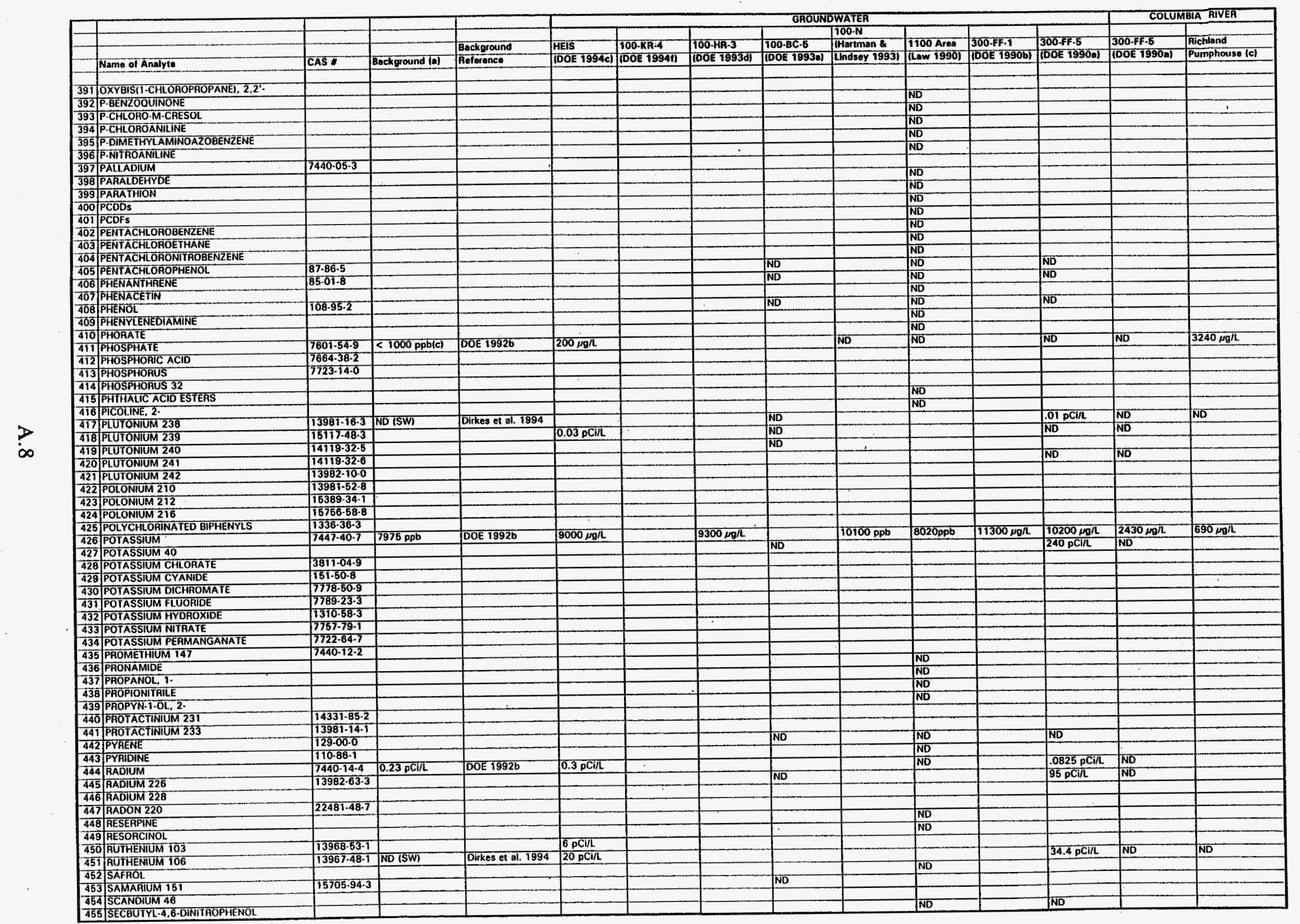




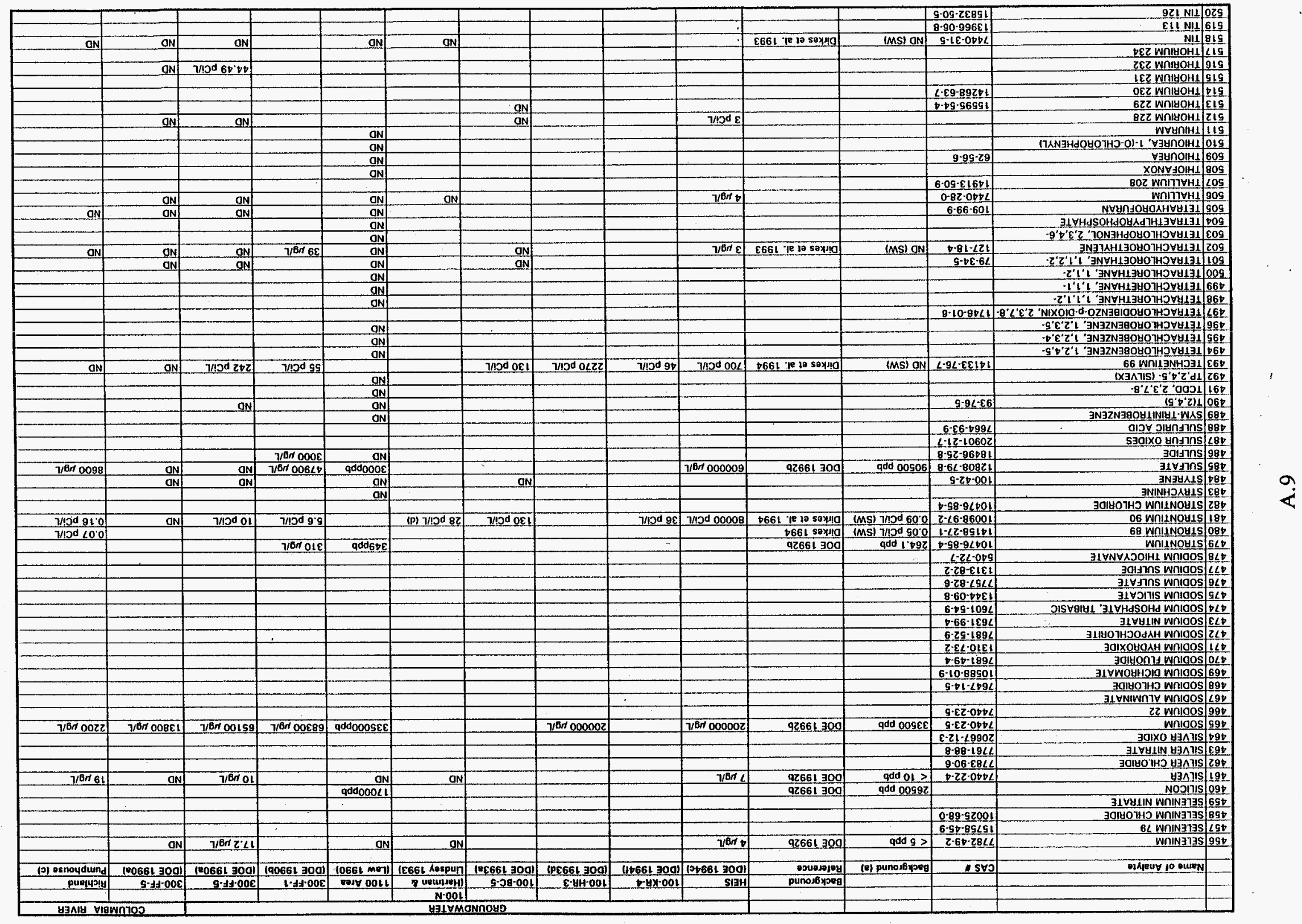

(płuos) ' $\mathbf{I} \cdot \mathbf{V}$ ə[qe $\mathbf{L}$ 


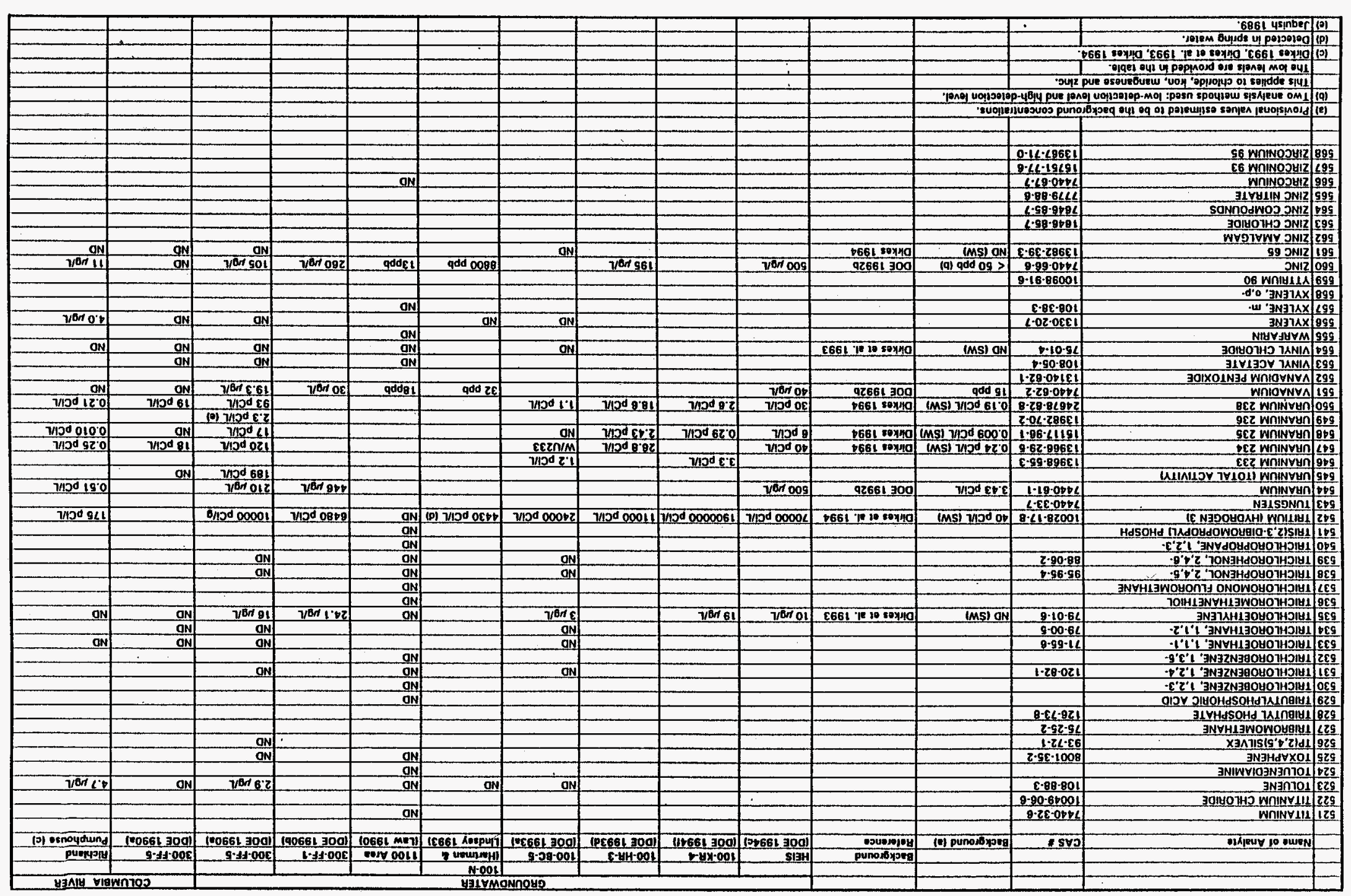

(płuos) ' ' I'V ग गqE $\mathbf{L}$ 
Table A.2. Radionuclide and Chemical Activity/Concentrations in Soil and Sediment

\begin{tabular}{|c|c|c|c|c|c|c|c|c|c|c|c|c|c|c|}
\hline-1 & & & & & & & & & Soll & & & & SEDII & MENT \\
\hline & Name of Analyte & CAS \#- & Background(a) & \begin{tabular}{|l|} 
Background \\
Reference
\end{tabular} & $\begin{array}{l}\text { 100-KR-4 } \\
\text { (DOE 1994h) }\end{array}$ & $\begin{array}{l}\text { foO-HA-1 } \\
\text { (DOE 1993G) }\end{array}$ & \begin{tabular}{|l|}
$100-B C-1$ \\
(DOE 1994d)
\end{tabular} & \begin{tabular}{|l|}
$00-B C-5$ \\
(DOE 1993a)
\end{tabular} & $100-N(b)$ & $\begin{array}{l}1100 \text { Area } \\
\text { Law 1990) }\end{array}$ & $\begin{array}{l}300-F F-1 \\
\text { (DOE 1990b) }\end{array}$ & \begin{tabular}{|l|}
$300-F F-5$ \\
(DOE f990a)
\end{tabular} & 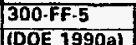 & $\begin{array}{l}100 \text { Areas } \\
\text { Weiss } 19931\end{array}$ \\
\hline & & & & & & & & & & & & & & \\
\hline$\frac{1}{2}$ & $\begin{array}{l}\text { ACENAPHTHENE } \\
\text { ACEAPHTHYIENE }\end{array}$ & $83 \cdot 32 \cdot 9$ & ND & DOE 1994a & & $210 \mu \mathrm{g} / \mathrm{kg}$ & & & IND & & & & & \\
\hline$\frac{2}{3}$ & $\begin{array}{l}\text { ACENAPHTHYLENE } \\
\text { ACETONE }\end{array}$ & $\frac{208 \cdot 96 \cdot 8}{67-64 \cdot 1}$ & ND & DOE 1994a & & & & & IND & & & & & \\
\hline 4 & $\begin{array}{l}\text { ACETONE } \\
\text { ACETOPHENONE }\end{array}$ & $\begin{array}{l}67-64-1 \\
98-86-2\end{array}$ & $\begin{array}{l}\text { NDD } \\
\text { NOE }\end{array}$ & $\begin{array}{l}\text { DUE 1999a } \\
\text { DOE 1990b }\end{array}$ & & & & & & & NDD & ND & ND & a \\
\hline & ACETYLAMINOFLUORENE, 2 . & $53-96-3$ & ND & DOE 1990b & & & & & & & NND & & & \\
\hline 6 & ACAYLLAMIDE & $79-06 \cdot 1$ & ND & DOE 1990b & & & & & & & & & & \\
\hline & ACROLEIN & $107.02 \cdot 8$ & ND & DOE 1990b & & & & & & & ND & & & \\
\hline 8 & ACRYLONITRILE & 107.13 .1 & NO & DOE 1990b & & & & & & & ND & & & \\
\hline 9 & ACTINIUM 227 & 14952.40 .0 & & & & & & & & & & & & \\
\hline 10 & ALDRIN & $309 \cdot 00 \cdot 2$ & ND & DOE 1994a & & & & & & & & & & \\
\hline 11. & ALLYL ALCOHOL & $107 \cdot 18-6$ & No & DOE 19906 & & & & & & & & & & \\
\hline 12 & ALPHA, ALPHA-DIMETHYLPHENETHYLAMINE & $99 \cdot 98 \cdot 9$ & NO & DOE 1990b & & & & & & & ND & & & \\
\hline 13 & ALPHA-BHC & $319-84-6$ & ND & DOE 1994a & & & & & & & & & & \\
\hline 14 & ALPHA.CHLORDANE & $5103-71-9$ & ND & DOE 1994a & & & & & & & & & & \\
\hline 15 & ALUMINUM & $7429-90-5$ & $13621 \mathrm{mg} / \mathrm{kg}$ & DOE 1994a & $7700 \mathrm{mg} / \mathrm{kg}$ & $9070 \mathrm{mg} / \mathrm{kg}$ & $12500 \mathrm{mg} / \mathrm{kg}$ & & & & $26.700 \mathrm{mg} / \mathrm{kg}$ & $8760 \mathrm{mg} / \mathrm{kg}$ & $6750 \mathrm{mg} / \mathrm{kg}$ & $9,350 \mathrm{mg} / \mathrm{kg}$ \\
\hline 16 & ALUMINUM NITRATE & 13473.90-0 & & & & & & & & & & & & \\
\hline 17 & ALUMINUM SULFATE & 10043.01 .3 & & & & & & & & & & - & & \\
\hline 18 & AMERICIUM 241 & $7440-35 \cdot 9$ & & & & $0.72 \mathrm{pCi} / \mathrm{g}$ & $34 \mathrm{pCl} / \mathrm{g}$ & & & & & -1 & & ND \\
\hline \begin{tabular}{c|}
19 \\
20 \\
\end{tabular} & AMERICIUM 242M & \begin{tabular}{|l|}
$13981-54-9$ \\
14993.75 .0
\end{tabular} & & & & & & & & & & & & \\
\hline 20 & $\begin{array}{l}\text { AMERCOUM } 243 \\
\text { AMINOBYPHENYL, } 4\end{array}$ & $\left|\frac{119933-75-0}{922-67-1}\right|$ & ND & DOEE 19906 & & & & & & & & & & \\
\hline 22 & AMINOMETHYL-3 ISDAZOLOL, 5- & $2763-96-4$ & ND & DOE $1990 \mathrm{~b}$ & & & & & & & $\frac{N D}{N D}$ & & & \\
\hline 23 & AMITROLE & 61.82 .5 & ND & DOE 19906 & & & & & & & ND & & & \\
\hline 24 & AMMONIA & $7664.41-7$ & $16.0 \mathrm{mg} / \mathrm{kg}$ & DOE 1994a & & & & & & & & $12.8 \mathrm{mg} / \mathrm{kg}$ & $12 \mathrm{mg} / \mathrm{kg}$ & \\
\hline 25 & AMMONIUM & $14798-03-9$ & ND & DOE 1990b & & & & & & & & & & \\
\hline 26 & AMMONIUM ACETATE & 631.61 .8 & & & & & & & & & & & & \\
\hline 27 & AMMONIUM CARBONATE & $506 \cdot 87 \cdot 6$ & & & & & & & & & & & & \\
\hline 28 & $\begin{array}{l}\text { AMMONIUM CHLORIDE } \\
\end{array}$ & $\mid 12125-02-9$ & & & & & & & & & & & & \\
\hline 29 & AMMONIUM FLUOAIDE & $12125-10-8$ & & & & & & & & & & & & \\
\hline 30 & AMMONIUM NITRATE & $6484.52-2$ & & & & & & & & & & & & \\
\hline 31 & AMMONIUM OXALATE & |1113-38-8 & & & & & & & & & & & & \\
\hline 32 & AMMONIUM SILLCOFLUORIDE & $1309 \cdot 32 \cdot 6$ & & & & & & & & & & & & \\
\hline 33 & AMMONIUM SULFATE & $7783-20-2$ & & & & & & & & & & & & \\
\hline 34 & AMMONIUM SULFITE & 10196-04-0 & & & & & & & & & & & & \\
\hline 35 & AMMONIUM THIOSULFATE & $7783-18-8$ & & & & & & & & & & & & \\
\hline 36 & ANILINE & $62 \cdot 53 \cdot 3$ & NDO & DOE 1990b & & & & & & & ND & & & \\
\hline 37 & ANTHAACENE & $120 \cdot 12 \cdot 7$ & NDD & DOE 1994a & & $430 \mu \mathrm{g} / \mathrm{kg}$ & & & ND & & & & & \\
\hline 38 & ANTIMONY & $7440 \cdot 36 \cdot 0$ & NDD & DOE 1994a & & & NDD & & & & No & ND & NO & No \\
\hline 39 & ANTIMONY (iii) NITRATE & $20328 \cdot 96 \cdot 5$ & & & & & & & & & & & & \\
\hline 40 & ANTIMONY 124 & $7440-36-0$ & & & & & & & & & & & & $1.2 \mathrm{pCi} / \mathrm{kg}$ \\
\hline 41 & ANTIMONY 125 & $\mid 14234-35-6$ & & & & & & & & & & & ND & \\
\hline 42 & ANTIMONY CHLORIDE & 10025-9-19 & & & & & & & & & & & & \\
\hline 43 & AAAMITE & 140.57 .8 & ND & DOOE 1990b & & & & & & & ND & & & \\
\hline 44 & AROCHLOR-1221 & $111104-28-2$ & ND & DOE 1994a & & & &. & & & ND & ND & 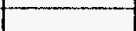 & \\
\hline 45 & AROCHLOR-1232 & $11141-16-6$ & NDD & DOE 1994a & & & & & & & ND & ND & & \\
\hline 46 & AROCHLOR-1260 & $11096-82-5$ & NDD & DOE 1994a & & & & & & & ND & ND & & \\
\hline & AROCLOR 1016 (PCB) & $12674-11-2$ & ND & DOE 1994a & & & 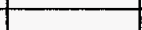 & & & & MD & TR & & \\
\hline 48 & AROCLOA 1242 (PCB) & $53469-21-9$ & ND & DOE 1994a & & & & & & & No & ND & & \\
\hline 49 & $\overline{A R O C L O A} 1248$ (PCB) & $|12672 \cdot 29 \cdot 6|$ & ND & DOE 1994a & & & & & & & $9.9 \mathrm{mg} / \mathrm{kg}$ & ND & & \\
\hline 50 & AROCLOR 1254 (PCB) & $\mid 11091-69-1$ & ND & DOE 1994a & & & & & & & NO & ND & & \\
\hline 51 & ARSENIC & $7440-38-2$ & $7.6 \mathrm{mg} / \mathrm{kg}$ & DOE 19943 & & $47 \mathrm{mg} / \mathrm{kg}$ & $2.2 \mathrm{mg} / \mathrm{kg}$ & & & & ND & $9.3 \mathrm{mg} / \mathrm{kg}$ & $7.5 \mathrm{mg} / \mathrm{kg}$ & \\
\hline 52 & \begin{tabular}{|l} 
ARSENIC TAIOXIDE \\
\end{tabular} & $1327-53-3 \mid$ & & & & & & & & & & & & \\
\hline 53 & $\begin{array}{l}\text { ASBESTOS } \\
\text { ASESTS }\end{array}$ & $3332-21 \cdot 4$ & & & & & & & & & & & & \\
\hline & AURAMINE & 492.80 .8 & ND & DOE 1990b & & & & & & & ND & & & \\
\hline 55 & BARIUM & $7440-39-3$ & $155.9 \mathrm{mg} / \mathrm{kg}$ & DOE 1994a & $85 \mathrm{mg} / \mathrm{kg}$ & $672 \mathrm{mg} / \mathrm{kg}^{*}$ & $484 \mathrm{mg} / \mathrm{kg}$ & & & & $133 \mathrm{mg} / \mathrm{kg}$ & $260 \mathrm{mg} / \mathrm{kg}$ & $67.3 \mathrm{mg} / \mathrm{kg}$ & $120 \mathrm{mg} / \mathrm{kg}$ \\
\hline 56 & BĀRIUM 133 & 13989.41 .4 & & & & & & & & & & & & \\
\hline 57 & BAAIUM 140 & $7440 \cdot 39 \cdot 3$ & & & & & No & & & & & No & & \\
\hline 58 & BABRIUM NITRATE & $10022 \cdot 31 \cdot 8$ & & & & & & & & & & & & \\
\hline
\end{tabular}


Table A.2. (contd)

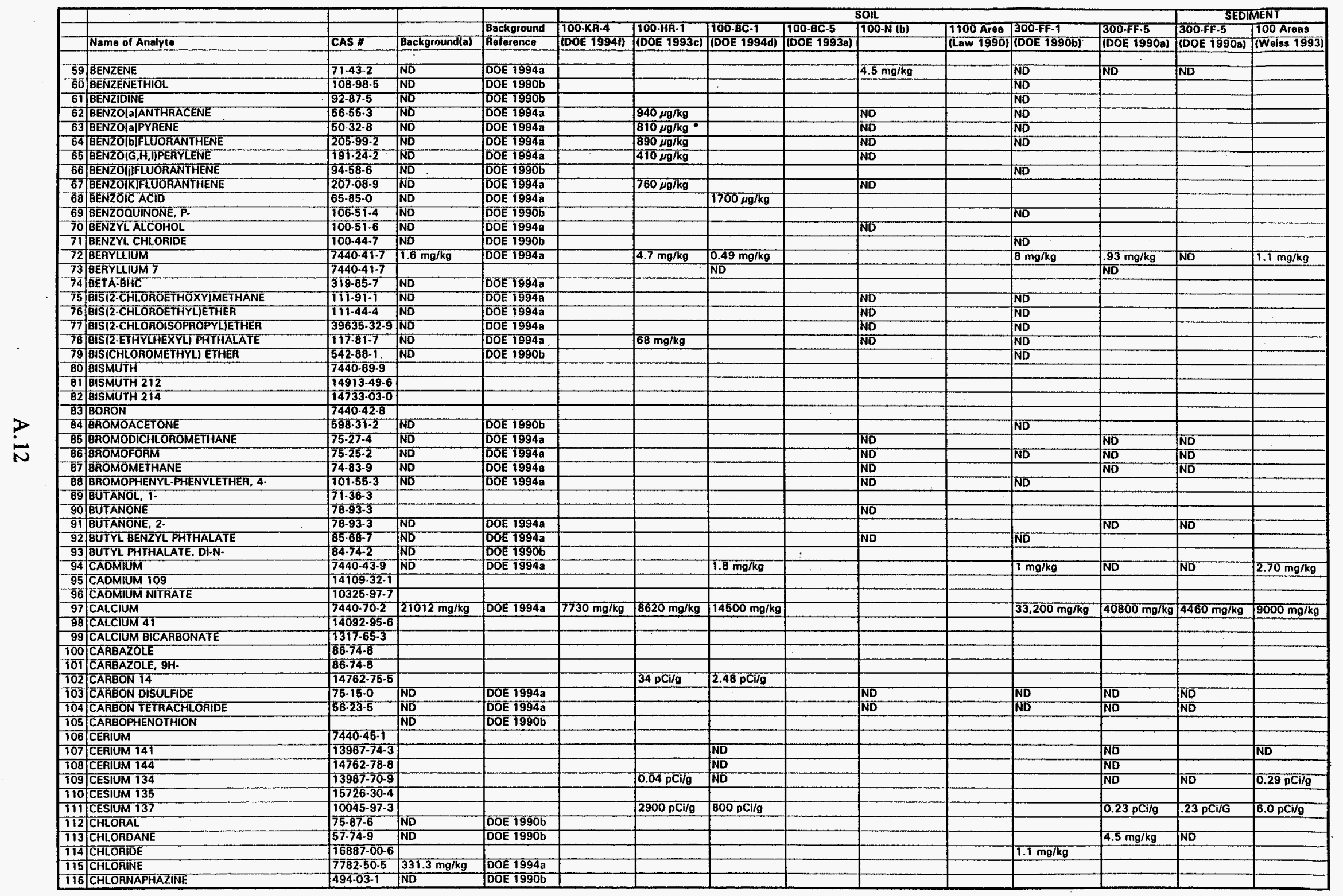


Table A.2. (contd)

\begin{tabular}{|c|c|c|c|c|c|c|c|c|c|c|c|c|c|c|}
\hline \multirow{3}{*}{ 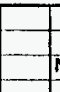 } & \multirow{3}{*}{ Name of Analyte } & \multirow{3}{*}{ CAS I } & \multirow{3}{*}{ Background(a) } & \multirow{3}{*}{\begin{tabular}{|l|} 
Background \\
Agference \\
\end{tabular}} & \multirow{3}{*}{$\begin{array}{l}\text { 100-KR-4 } \\
\text { (D0E 19941) }\end{array}$} & \multirow{3}{*}{\begin{tabular}{|l} 
100-HR-1 \\
(DOE 1993C)
\end{tabular}} & \multirow{3}{*}{$\begin{array}{l}100-B C-1 \\
\text { DDOE 1994d } \\
\end{array}$} & \multirow{3}{*}{\begin{tabular}{|l|}
$100-B C-5$ \\
$1 D O E-1993 a)$ \\
\end{tabular}} & \multicolumn{4}{|l|}{ SOIL } & \multicolumn{2}{|c|}{$\begin{array}{l}\text { SEDIMENT } \\
\end{array}$} \\
\hline & & & & & & & & & $100-\mathrm{N}(\mathrm{b})$ & \begin{tabular}{|l|}
1100 \\
\end{tabular} & 300-FF-1 & 300.FF.5 & \begin{tabular}{|l|l|}
300 .FF-5 \\
CDOE 1990a
\end{tabular} & $\begin{array}{l}00 \text { Areas } \\
\text { Wolss 19931 }\end{array}$ \\
\hline & & & & & & & & & & & & & & \\
\hline 117 & CHLORO-2,3-EPOXYPROPANE, 1- & & ND & DOE 1990b & & & & & & & ND & & & \\
\hline i10 & CHLORO-M-CRESOL, P- & 59-50-7 & NDD & DOE 1990b & & & & & & & ND & & & \\
\hline 119 & CHLOAOACETALDEHYDE & $107 \cdot 20 \cdot 0$ & ND & DOE $1990 \mathrm{~b}$ & & & & & & & & & & \\
\hline 120 & CHLOROALKYL ETHERS & & ND & DOE 1990b & & & & & & & ND & & & \\
\hline 121 & CHLOROANILINE, 4 - & $106-47-8$ & ND & DOE 1994a & & & & & NDD & & & & & \\
\hline T22 & CHLOROBENZENE & 108.90 .7 & ND & DOE 1994a & & & & & ND & & ND & ND & NDD & \\
\hline 123 & CHLOROBENZILATE & $510-15-6$ & NO & DOE $1990 \mathrm{~b}$ & & & & & & & & & & \\
\hline 124 & CHLORODIBAOMOMETHANE & $124-48-1$ & & DOE 1994a & & & & & & & & & & \\
\hline 125 & CHLOROETHANE & $75-00-3$ & ND & DOE 1994a & & & & & ND & & & NDD & ND & \\
\hline 126 & CHLOROETHOXY ETHENE, 2- & 110.75 .8 & & & & & & & & & & NO & NDD & \\
\hline 127 & CHLOROETHYYVINYL ETHER, 2 - & $110-75-8$ & IND & DOE 1990b & & & & & & & ND & & & \\
\hline 128 & CHLOROFOAM & $67.66 \cdot 3$ & ND & DÖE 1994a & & 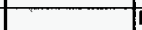 & ND & & ND & & ND & ND & ND & \\
\hline$\overline{129}$ & CHLOROMETHANE & $74 \cdot 87 \cdot 3$ & ND & DOE $1994 a$ & & & & & ND & & & ND & ND & \\
\hline 130 & CHLOROMETHYLMETHYL ETHER & $107-30-2$ & ND & DOE 1990b & & & & & & & ND & & & \\
\hline 131 & CHLOROMETHYLPHENOL, 4-3- & $35421-08-0$ & & & & & & & NO & & & & & \\
\hline 132 & CHLORONAPHTHALENE, 2 - & 91.58 .7 & NDD & DOE 1994a & & & & & NDO & & NDD & & & \\
\hline 133 & CHLOROPHENOL, 2 - & $95-57.8$ & ND & DOE 1994a & & & & & NDD & & ND & & & \\
\hline 134 & CHLOAOPHENYL-PHENYL ETHER, 4- & $7005 \cdot 72 \cdot 3$ & ND & DOE 1994a & & & & & ND & & & & & \\
\hline T35 & ČCHLOROPROPIONITRILE, 3- & $542 \cdot 76 \cdot 7$ & ND & DOE 1990b & & & & & & & & & & \\
\hline$\overline{13 \overline{6}}$ & CHROMIC ACID & $7738-94-5$ & & & & & & & & & & & & \\
\hline 137 & CHROMMUM & $7440-47 \cdot 3$ & $24.1 \mathrm{mg} / \mathrm{kg}$ & DOE 1994a & & $114 \mathrm{mg} / \mathrm{kg}$ & $20.2 \mathrm{mg} / \mathrm{kg}$ & & & & $259 \mathrm{mg} / \mathrm{kg}$ & $28.9 \mathrm{mg} / \mathrm{kg}$ & $13.8 \mathrm{mg} / \mathrm{kg}$ & $122 \mathrm{mg} / \mathrm{kg}$ \\
\hline 138 & CHROMIUM (IV) & $15723-28-1$ & & & & & & & & & & & & \\
\hline 139 & CHROMIUM IVI) & $18540-29-9$ & & & & & & & & & & & & \\
\hline 140 & CHROMIUM 51 & $14392-02-0$ & & & & & NDE & & & & & ND & ND & NO \\
\hline 141 & CHROMUUM NITRATE & 13548-38-4 & & & & & & & & & & & & \\
\hline $1 \overline{4} \overline{2}$ & CHROMUUM SULFATE & $10101-53-8$ & & & & & & & & & & & & \\
\hline 143 & CHRYSENE & $218 \cdot 01 \cdot 9$ & NO & DOE 1994a & & $920 \mu \mathrm{gg} / \mathrm{kg}$ & & & NO & & ND & & & \\
\hline 144 & CITRIS RED & $6358-63-8$ & ND & DOE $1990 \mathrm{~b}$ & & & & & & & & & & \\
\hline 145) & COBAALT & $7440-48-4$ & $17.6 \mathrm{mg} / \mathrm{kg}$ & DOOE 1994a & $14.2 \mathrm{mg} / \mathrm{kg}$ & $9.9 \mathrm{mg} / \mathrm{kg}$ & $16.4 \mathrm{mg} / \mathrm{kg}$ & & & & & $34.1 \mathrm{mg} / \mathrm{kg}$ & ND & $11.5 \mathrm{mg} / \mathrm{kg}$ \\
\hline 146 & COBALT 58 & 13981-38-9 & & & & & & & & & & & & \\
\hline 147 & COBALT 60 & $10198.40 \cdot 0$ & ND & DOE 1990b & & $18000 \mathrm{pCi} / \mathrm{g}$ & $310 \mathrm{pCi} / \mathrm{g}$ & & & & & $0.78 \mathrm{pCl} / \mathrm{g}$ & $0.78 \rho \mathrm{Ci} / \mathrm{g}$ & $4,9 \mathrm{pCi} / \mathrm{g}$ \\
\hline 148 & COPPER & $7440-60-8$ & $25.9 \mathrm{mg} / \mathrm{kg}$ & DOE 1994a & $9 \mathrm{mg} / \mathrm{kg}$ & $140000 \mathrm{mg} / \mathrm{k}$ & $27.8 \mathrm{mg} / \mathrm{kg}$ & & & & $2850 \mathrm{mg} / \mathrm{kg}$ & NO & $16.1 \mathrm{mg} / \mathrm{kg}$ & $40 \mathrm{mg} / \mathrm{kg}$ \\
\hline 149 & COPPER NITRATE & $3251-23-8$ & & & & & & & & & & & & \\
\hline 150 & COPPEA SULFATE & $755 \overline{8.98 .7}$ & & & & & & & & & & & & \\
\hline 151 & CRESOLS & $1319.77 \cdot 3$ & ND & DOE 1990b & & & & & & & NO & & & \\
\hline 152 & CFOTONALDEHYDE & $123.73 \cdot 9$ & ND & DOE 1990b & & & & & & & ND & & & \\
\hline 153 & CUAIUM 242 & $15510-73-3$ & & & & & & & & & & & 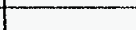 & \\
\hline 154 & CURIUM 244 & $13981 \cdot 15 \cdot 2$ & & & & & & & & & & & 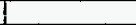 & \\
\hline 155 & CURIUM 245 & $15621 \cdot 76 \cdot 8$ & & & & & & & & & & & & \\
\hline i56 & CYANIDE & $57 \cdot 12-5$ & NO & DOE 1990b & & & $1.05 \mathrm{mg} / \mathrm{kg}$ & & & & & ND & NO & \\
\hline 157 & CYANOGEN & $460-19-5$ & IND & $D O E$ 1990b & & & & & & & & & & \\
\hline 158 & CYANOGEN CHLOAIDE & $506-77-4$ & NNO & DOE 1990b & . & & & & & & & & $\mathrm{C}_{\mathrm{T}}$ & \\
\hline 159 & CYANOGEN BROMIDE & $506-68-3$ & & & & & & & & & & & & \\
\hline 160 & CYCLOHEXYL-4,6-DINITROPHENOL, 2 - & 131-89.5 & NO & DOE 1990b & & & & & & & NND & & & \\
\hline 161 & $0(2,4)$ & $94.75 \cdot 7$ & NO & DOE 1990b & & & & & & & & & & \\
\hline 162 & DOD, $4.4^{\circ}$ & $72-54-8$ & NO & DOE 1994a & & & & & & & & & & \\
\hline 163 & DDE, $4,4^{4}$ & $72-55-9$ & No & DOE 1994a & & & & & & & & & & \\
\hline 164 & DDT, 4,4:- & $50-29-3$ & NA & DOE 1994a & & & & & & & & & 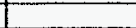 & \\
\hline 165 & DELTA-BHC & $319-86-8$ & NDD & DOE 1994a & & & & & & & & & & \\
\hline 166 & DI-N-BUTYLPHTHALATE & $\overline{84-74-2}$ & Nล̃ & DOE 1994a & & & & & ND & & ND & & & \\
\hline 167 & DI-N-OCTYLPHTHALATE & $117-84-0$ & Nō & DOE 1994a & & & & & ND & 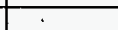 & ND & & & \\
\hline 168 & DI-N-PROPYLNITROSAMINE & $621-64-7$ & ND & DOE 1990b & & & & & & & $\mathrm{ND}$ & & & \\
\hline 169 & DIBENZ(A,G)ANTHRACENE & $53-70-3$ & & & & & & & & & & & & \\
\hline 170 & DIBENZIA,HIACRIDINE & $226-36-8$ & ND & DOE 1990b & & & & & & & ND & & & \\
\hline 171 & DIBENZ $(A, H) A N T H R A C E N E$ & 53.70 .3 & ND & DOE 1994a & & & & & ND & & ND & & & \\
\hline 172 & DIBENZ(A, J)ACRIDINE & $\longdiv { 2 2 4 - 4 2 - 0 }$ & WD & DOE $1990 \mathrm{~b}$ & & & & & & & ND & & & \\
\hline 173 & DIBENZOIA,EIPYRENE & 192-65-4 & JND & DOE $1990 \mathrm{~b}$ & & & & & & & No & & & \\
\hline 174 & DIEENZO(A,H)PYAENE) & $189 \cdot 64 \cdot 0$ & ND & DOE 19906 & & & & & & & ND & & & \\
\hline
\end{tabular}


Table A.2. (contd)

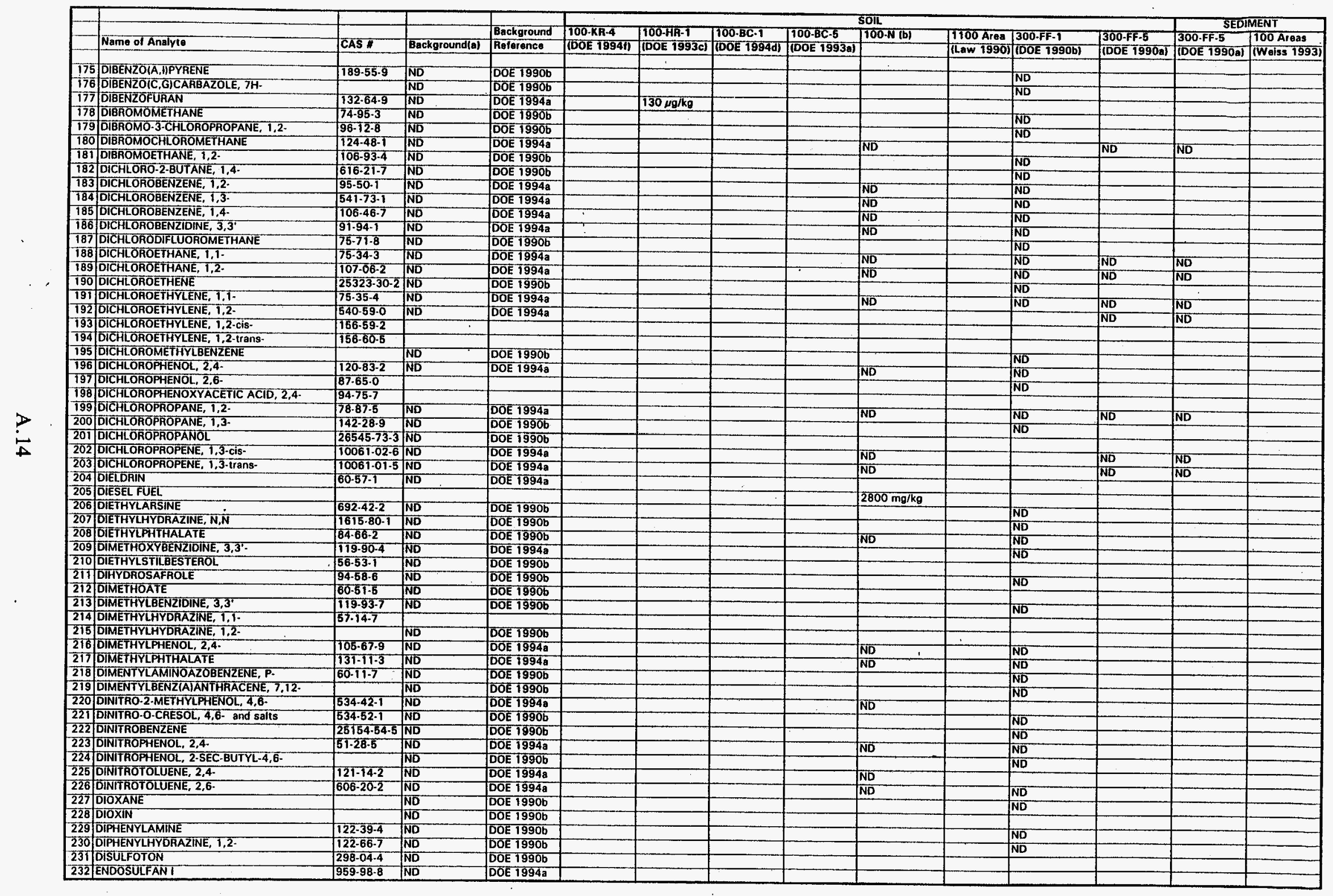


Table A.2. (contd)

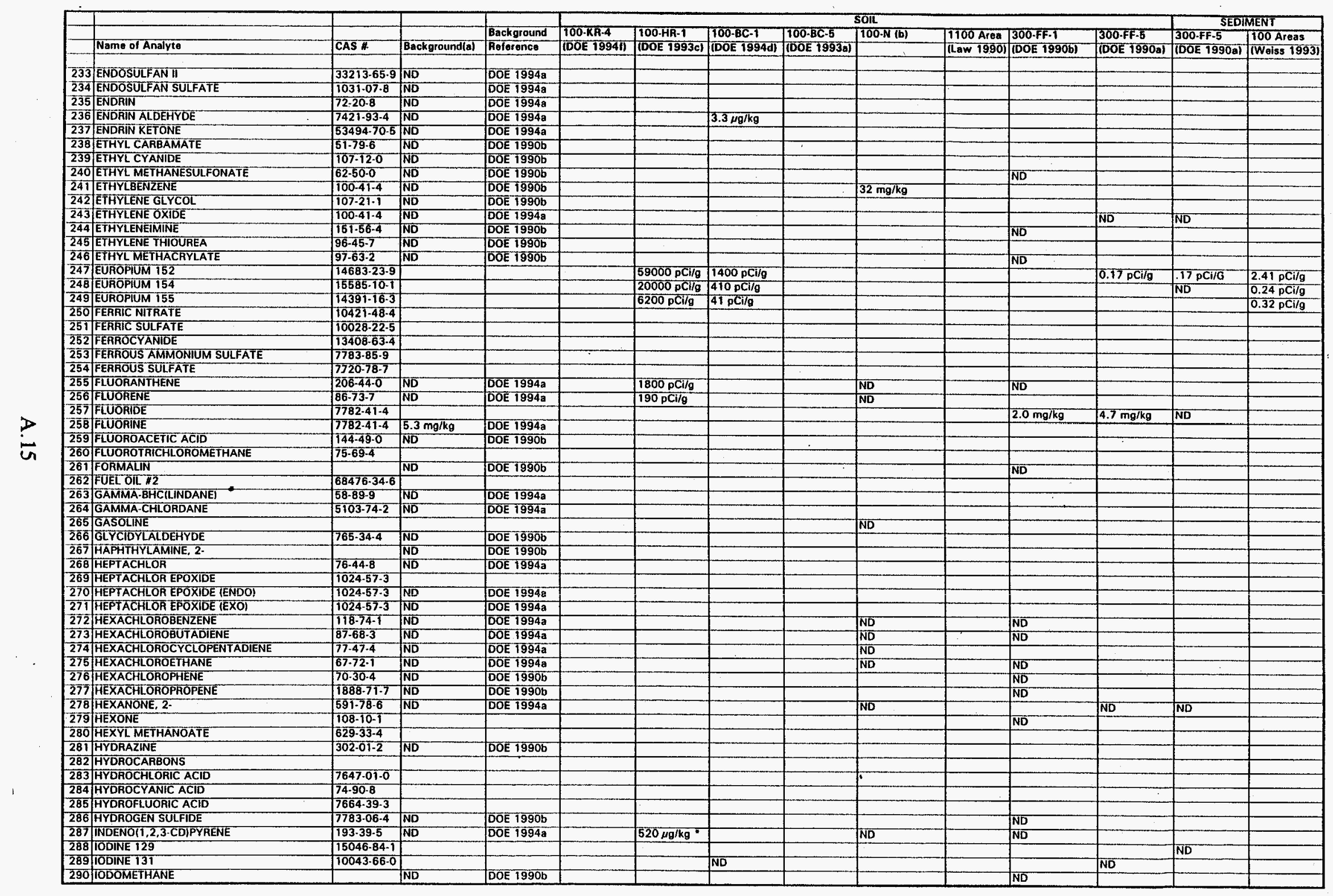


Table A.2. (contd)

\begin{tabular}{|c|c|c|c|c|c|c|c|c|c|c|c|c|c|c|}
\hline & \multirow{2}{*}{ Name of Anolyte } & \multirow{3}{*}{ CAS: } & \multirow{3}{*}{ Backgroundia) } & \multirow{3}{*}{\begin{tabular}{|l|} 
Background \\
Reference \\
\end{tabular}} & \multirow{2}{*}{\begin{tabular}{|l|} 
100-KR-4 \\
00 10 1994II
\end{tabular}} & \multirow{2}{*}{$\begin{array}{l}\text { 100-HA-1 } \\
\text { (DOE 1993G) }\end{array}$} & \multirow{3}{*}{$\begin{array}{l}100-\mathrm{BC}-1 \\
\text { (DOE 1994d) }\end{array}$} & \multirow{3}{*}{$\begin{array}{l}100 \cdot-8 C-5 \\
(100 E-1993 a)\end{array}$} & \multicolumn{4}{|l|}{ Soll } & \multicolumn{2}{|c|}{ SEDIMENT } \\
\hline & & & & & & & & & $100 \mathrm{~N}(\mathrm{~b})$ & 1100 Area & $300-F-1$ & 300-FF.5 & $300-F-5$ & 100 Areas \\
\hline & & & & & & & & & & & & & & (Wolss 1993) \\
\hline 291 & IIRON & 7439.89 .6 & $35746 \mathrm{mg} / \mathrm{kg}$ & DOE 1994a & $25500 \mathrm{mg} / \mathrm{kg}$ & $19000 \mathrm{mg} / \mathrm{kg}$ & $44600 \mathrm{mg} / \mathrm{kg}$ & & & & $33,500 \mathrm{mg} / \mathrm{kg}$ & $19500 \mathrm{mg} / \mathrm{kg}$ & $17000 \mathrm{mg} / \mathrm{kg}$ & $171000 \mathrm{mg} / \mathrm{k}$ \\
\hline$\overline{2} \overline{9} \overline{2}$ & RRON 59 & & & & & & & & & & & ND & ND & ND \\
\hline 293 & JISOBUTYL ALCOHOL & 78.83 .1 & ND & DOE 1990b & & & & & & & & & & \\
\hline 294 & ISOPHORONE & $78.5 \overline{9} \cdot 1$ & ND & DOE 1994a & & & & & ND & & & & & \\
\hline 295 & ISOSAFROLE & 120-58-1 & NOD & DOE 1990b & & & & & & & NO & & & \\
\hline 296 & KEROSENE & $6 \overline{0008-20-6}$ & $\overline{N D}$ & DOE 19906 & & & & & $3085 \mathrm{mg} / \mathrm{kg}$ & & NO & & & \\
\hline 297 & KAYPTON 85 & & & & & & & & & & & & & \\
\hline 298 & LANTHANUM & $7439.91-0$ & & & & & & & & & & & & \\
\hline 299 & LEAD & $7439-92-1$ & $12.6 \mathrm{mg} / \mathrm{kg}$ & DOE 1994a & $7.6 \mu \mathrm{g} / \mathrm{L}$ & $540 \mathrm{mg} / \mathrm{kg}$ & $4.8 \mathrm{mg} / \mathrm{kg}$ & & & & ND & $15.6 \mathrm{mg} / \mathrm{kg}$ & $17.4 \mathrm{mg} / \mathrm{kg}$ & $73 \mathrm{mg} / \mathrm{kg}$ \\
\hline 300 & LEAD 210 & $14255-04-0$ & & & & & & & & & & & 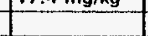 & 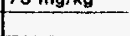 \\
\hline 301 & LEAD 212 & 15092-94-1 & & & & & & & & & & & & \\
\hline 302 & LEAD NITRATE & 10099.74 .6 & & & & & & & & & & & & \\
\hline $30 \overline{3}$ & LITHIUM & $7439-93-2$ & $35 \mathrm{mg} / \mathrm{kg}$ & DOE 1994a & & & & & & & & & & \\
\hline 304 & LITHIUM CHLOAIDE & $7447-41-8$ & & & & & & & & & & & & \\
\hline 305 & MAGNESIUM & $7439-95-4$ & $8169 \mathrm{mg} / \mathrm{kg}$ & DOE 1994a & $5030 \mathrm{mg} / \mathrm{kg}$ & $4720 \mathrm{mg} / \mathrm{kg}$ & $6390 \mathrm{mg} / \mathrm{kg}$ & & & & $11,600 \mathrm{mg} / \mathrm{kg}$ & $8540 \mathrm{mg} / \mathrm{kg}$ & $4020 \mathrm{mg} / \mathrm{kg}$ & $7600 \mathrm{mg} / \mathrm{kg}$ \\
\hline 306 & MALEIC HYDRAZIDE & $\overline{223-33-1}$ & & DOE $1990 \mathrm{~b}$ & & & & & & & & & & \\
\hline 307 & MALONONITAILE & $109-77 \cdot 3$ & ND & DOE 1990b & & & & & & & NO & & & \\
\hline 308 & MANGANESE & $7439-96-5$ & $548 \mathrm{mg} / \mathrm{kg}$ & DOE 1994a & $330 \mathrm{mg} / \mathrm{kg}$ & $3050 \mathrm{mg} / \mathrm{kg}$ & $839 \mathrm{mg} / \mathrm{kg}$ & & & & $396 \mathrm{mg} / \mathrm{kg}$ & $403.2 \mathrm{mg} / \mathrm{kg}$ & $327 \mathrm{mg} / \mathrm{kg}$ & $578 \mathrm{mg} / \mathrm{kg}$ \\
\hline 309 & MANGANESE 54 & $13966-31.9$ & & & & & ND & & & & & ND & & $0.057 \mathrm{pC} / 9$ \\
\hline 310 & MELPHALAN & $148-82-3$ & ND & DOE 1990b & & & & & & & No & & & \\
\hline 311 & MERCURIC NITAATE & $10045-95-0$ & & & & & & & & & & & & \\
\hline 312 & MERCURIC THIOCYANATE & $592-85-8$ & & & & & & & & & & & & \\
\hline$\overline{313}$ & MEACUAY & $7439-97.6$ & $0.61 \mathrm{mg} / \mathrm{kg}$ & DOE 1994a & $1.4 \mathrm{mg} / \mathrm{kg}$ & $1.1 \mathrm{mg} / \mathrm{kg}$ & $4.3 \mathrm{mg} / \mathrm{kg}$ & & & & $2.77 \mathrm{mg} / \mathrm{kg}$ & $.54 \mathrm{mg} / \mathrm{kg}$ & No & NO \\
\hline 314 & METHACAYLONITRILE & 126-98-7 & ND & DOE $1990 \mathrm{~b}$ & & & & & & & ND & & & \\
\hline 315 & METHANAL & 50.00 .0 & & & & & & & & & & & & \\
\hline 316 & METHANETHIOL & 74-93-1 & ND & DOE 1990̄ & & & & & & & NO & & & \\
\hline 317 & METTHANOLL & $67.56-1$ & & & & & & & & & & & & \\
\hline 318 & METHAPYFILENE & $91-80.5$ & ND & DOE 1990b & & & & & 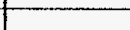 & & NOD & & & \\
\hline 319 & METHOLONYL & & ND & DOE $1990 \bar{b}$ & & & & & & & NO & & & \\
\hline 320 & METHOXYCHLOR & $72 \cdot 43 \cdot 5$ & ND & DOE 1994a & & & & & & & & & & \\
\hline$\overline{321}$ & METHYL BROMIDE & $74-83 \cdot 9$ & ND & DOE 1990b & & & & & & & ND & & & \\
\hline 322 & METHYL CHLOAIDE & $74-87.3$ & NO & DOE $1990 \mathrm{~b}$ & & & & & & & ND & & & \\
\hline 323 & METHYL ETHYL KETONE & 78.93 .3 & No & DŌE $1 \overline{990 b}$ & & & & & & & ND & & & \\
\hline 324 & METHYL METHACAYLATE & $80-62-6$ & ND & DOE $1990 \mathrm{~b}$ & & & & & & & ND & & - & \\
\hline$\overline{3} 25$ & METHYL METHANESULFONATE & $66 \cdot 27 \cdot 3$ & NO & DOE 1990b & & & & & & & ND & & & \\
\hline 326 & METHYY PARATHION & 298-00-0 & ND & DOE $1990 \mathrm{~b}$ & & & & & & & & & & \\
\hline 327 & METHYL-2-(METHYLIO)PROPIONALDEHYDE, 2 & & No & DOE 1990b & & & & & & & NO & & & \\
\hline 328 & METHYL-2-PENTANONE, 4- & $108-10-1$ & No & DOE 1994a & & & & & ND & & & $22 \mathrm{mg} / \mathrm{kg}$ & ND & \\
\hline 329 & METHYLAZZIRIDINE, 2 - & $75-55-8$ & ND & DOE 1990b & & & & & & & ND & & & \\
\hline 330 & METHYLCHOLANTHRENE, 3. & $56-49-5$ & NOS & DOE 1990b & & & & & & & NO & & & \\
\hline 331 & METHYLENE biS13.4.6-TAICHLOROPHENOLI & $70-30-4$ & & & & & & & & & & & & \\
\hline$\overline{332}$ & METHYLENE CHLOAIDE & 75.09-2 & ND & DOE 1994a & $120 \mu \mathrm{g} / \mathrm{kg}$ & & ND & & No & & NO & ND & ND & \\
\hline 333 & METHYLENE BIS(2-CHLOROANILINE), 4.4'. & 101.14 .4 & ND & DOE 19906 & & & & & & & ND & & & \\
\hline$\overline{334}$ & METHYLLHYDRAZINE & & NO & DOE $1990 \mathrm{~b}$ & & & & & & & & & & \\
\hline 335 & METHYLLACTONITRILE, 2 - & $75 \cdot 86-5$ & ND & DOE 1990b & & & & & & & NO & & & \\
\hline 336 & METHYLNAPHTHALENE, 2- & $91-57-6$ & ND & DOE 1994a & & $42 \mu \mathrm{g} / \mathrm{kg}$ & & & NO & & & & & \\
\hline 337 & METHYLPHENOL, 2. & $95-48.7$ & ND & DOE 1994a & & & & & NO & & & & & \\
\hline 338 & METHYLPHENOL, 4 . & 106-44.5 & NO & DOE 1994a & & & & & ND & & & & -1 & \\
\hline 339 & METHYLPHENOL, 4-CHLORO-3- & 59 & No & DOE $1994 a$ & & & & & & & & & & \\
\hline $34 \overline{0}$ & METHYLTHIOUAACIL & $56-04-2$ & No & DOE $1990 \mathrm{O}$ & & & & & & & ND & & & \\
\hline 341 & METHOXYCHLOA & $72-43.5$ & NO & DOE $19 \overline{90 b}$ & & & & & & & & & & \\
\hline$\overline{342}$ & MOLLYEDENUM & $7439-98-7$ & NO & DOE $1994 \mathrm{a}$ & & & & & & & & & & \\
\hline 343 & PAOPYLAMINE, N. & $107-10-8$ & NÓ & DOE 19 & & & & & & & & & & \\
\hline 344 & NAPHTHALENE & $91-20-7$ & ND & DOE 1994a & & & & & ND & & NO & & & \\
\hline 345 & NAPHTHOOUINONE, 1.4 - & $130-15-4$ & ND & DoE 1990b & & & & & & & NO & & & \\
\hline 346 & NAPHTHYLAMINE, 1 - & $91.59-8$ & No & DOE $1990 \mathrm{~b}$ & & & & & & & ND & & & \\
\hline 347 & NAPHTHYLAMINE, 2- & & ND & DOE $1990 \mathrm{~b}$ & & & & & & & & & & \\
\hline$\overline{34} \overline{8}$ & NEPTUNIUM 237 & $139994-20-2$ & & & & & & & & & & & & $\overline{0.606 \mathrm{pCi} / \mathrm{g}}$ \\
\hline
\end{tabular}


Table A.2. (contd)

\begin{tabular}{|c|c|c|c|c|c|c|c|c|c|c|c|c|c|c|}
\hline & \multirow{2}{*}{ Name of Analyte } & \multirow{3}{*}{ CAS : } & \multirow{2}{*}{ Background(a) } & \multirow{3}{*}{\begin{tabular}{|l|} 
Background \\
Raterence \\
\end{tabular}} & \multirow[b]{2}{*}{\begin{tabular}{|l|} 
100-KR-4 \\
(DOE 1994i) \\
\end{tabular}} & \multirow{3}{*}{$\begin{array}{l}\text { 100-HA-1 } \\
\text { (DOE 1993C) }\end{array}$} & \multirow{2}{*}{$\begin{array}{l}100-B C-1 \\
(D 00 \text { 1994d) }\end{array}$} & \multirow{3}{*}{\begin{tabular}{|l|}
$100 \cdot B C-5$ \\
(DOE 1993a) \\
\end{tabular}} & \multicolumn{4}{|l|}{ Soll- } & SEDI & MENT \\
\hline & & & & & & & & & $100 \cdot N(b)$ & 1100Area & 300-FF-1 & 300-FF-5 & 300-FF-5 & 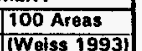 \\
\hline & & & & & & & & & & & & & & \\
\hline 349 & NEPTUNIUM 239 & 13968-59.7 & & & & & & & & & & & & \\
\hline 350 & NICKEE & $7440.02 \cdot 0$ & $22.2 \mathrm{mg} / \mathrm{kg}$ & DOE 1994a & $18 \mathrm{mg} / \mathrm{kg}$ & $132 \mathrm{mg} / \mathrm{kg}$ & $24.3 \mathrm{mg} / \mathrm{kg}$ & & & & $221 \mathrm{mg} / \mathrm{kg}$ & $17.2 \mathrm{mg} / \mathrm{kg}$ & $13.3 \mathrm{mg} / \mathrm{kg}$ & $19.7 \mathrm{mg} / \mathrm{kg}$ \\
\hline 351 & NICKEL 59 & $1 \overline{4} 336-70-0$ & & & & & & & & & & $0.0<\mathrm{mighg}$ & Do.0 mgrkg & $15.7 \mathrm{mg} / \mathrm{kg}$ \\
\hline 352 & NICKEL 63 & $13981-37.8$ & & & & $20000 \mathrm{pCi} / \mathrm{g}$ & & & & & & & & \\
\hline 353 & NICKELL FERROCYANIDE & $|14874-78-3|$ & & & & & & & & & & & & \\
\hline 354 & NICKEL NITAATE & $|13138-45-9|$ & & & & & & & & & & & & \\
\hline 355 & NICKEL SULFATE & 7786.81 .4 & & & & & & & & & & & & \\
\hline 356 & NICOTINIC ACID & & ND & DOE 1990b & & & & & & & ND & & & \\
\hline 357 & NIOB̈UM 95 & 13967.76 .5 & & & & & & & & & & & & \\
\hline 358 & NitTátATE & 14797.55 .8 & & & $4.3 \mathrm{mg} / \mathrm{kg}$ & & $5.9 \mathrm{mg} / \mathrm{kg}$ & & & & $30.4 \mathrm{mg} / \mathrm{kg}$ & $12.7 \mathrm{mg} / \mathrm{kg}$ & NOE & \\
\hline 359 & NITAIC ACID & $7697-37-2$ & & & & & o.t.nging & & & & 00.4 inging & (12, ong & Now & \\
\hline 360 & NITRITE & $|14797-65-0|$ & & & & & & & & & & NDD & ND & \\
\hline 3617 & NITAO-O-TOLUIDINE, 5- & $99-55.8$ & NDD & DOE 19906 & & & & & & & & jov & INo & \\
\hline $362 \pi$ & NIITOA ANILINE, 2- & 88.74 .4 & ND & DOE 1994a & & & & & NDD & & & & & \\
\hline 363 & NITROANIILNE, 3 - & $99 \cdot 09 \cdot 2$ & NO & DOE 1994a & & & & & ND & & & & & \\
\hline 364 & NITROANILINE, 4- & $100-01-6$ & ND & DOE 1994a & & & & & ND & & & & & \\
\hline 365 & NITROBENZENE & $98-95-3$ & ND & DOE 1994a & & & & & ND & & ND & & & \\
\hline 3664 & NITROGEN OXIDE & $10 \overline{024-97-2}$ & & & & & & & & & & & & \\
\hline 367 & NITROPHENOL, 2- & 88.75 .5 & NDO & DOE 1994a & & & & & NND & & & & & \\
\hline $368 \pi$ & NITROPPHENOL, 4- & $100.02-7$ & ND & DOE 1994a & & & & & ND & & ND & & & \\
\hline 369 & NITROSO-DI-N.PAOPYLAMINE, N- & $621 \cdot 64-7$ & ND & DOE 1994a & & & & & ND & & & & & \\
\hline 3700 & NITROSO-N-METHYLUAETHANE, N- & $615-53 \cdot 2$ & ND & DOE $1990 \mathrm{~b}$ & & & & & & & ND & & & \\
\hline 3716 & NITROSODI-N-BUTYLAMINE, N- & $924-16-3$ & ND & DOE 1990b & & & & & & & $\frac{N D}{N D}$ & & & \\
\hline $372 \pi$ & NITROSODIETHANOLAMINE, N- & $1116-54-7$ & ND & DOE $1990 \mathrm{~b}$ & & & & & & & WD & & & \\
\hline 373 & NITROSODIETHYLAMINE, N- & $55 \cdot 18-5$ & NDD & DOE 19906 & & & & & & & $\frac{N D}{N D}$ & & & \\
\hline $374 \pi$ & NITROSODIMETHYLAMINE, N- & \begin{tabular}{|l|}
$62-75-9$ \\
\end{tabular} & ND & DOE $1990 \mathrm{~b}$ & & & & & & & ND & & & \\
\hline 375 & NITROSODIPHENYLAMINE, N- & $\frac{8 \cdot 7 \cdot 30 \cdot 6}{86-6}$ & ND & DOE 1994a & & & & & NO & & ND & & & \\
\hline 376 & NITROSOMETHYLETHYLAMINE, N- & $10595-95 \cdot 6$ & ND & DOEE 1990b & & & & & & & NO & & & \\
\hline 377 & NITROSOMETHYLVINYLAMINE, $\mathrm{N}$ - & $4549-40-0$ & ND & DOE $1990 \mathrm{~b}$ & & & & & & & ND & & & \\
\hline 3781 & NITROSOMORPHOLINE, N- & 59.89 .2 & ND & DOE $1990 \mathrm{~b}$ & & & & & & & ND & & & \\
\hline 379 & NITROSONORNICOTINE, N- & $\mid 16543 \cdot 55 \cdot 8$ & ND & DOE $1990 \mathrm{~b}$ & & & & & & & ND & & & \\
\hline 360 & NITROSOPIPEAIDINE, N- & $100.75 \cdot 4$ & NOD & DOE 1990b & & & & & & & ND & & & \\
\hline 3817 & NITROSOPYAROLIDINE & 930-55-2 & ND & DOE $1990 \mathrm{~b}$ & & & & & & & ND & & & \\
\hline 382 & OATHO-PHOSPHATE & & & & & & & & & & & & & \\
\hline 383्रा & OSMIUM & & ND & DOE $1990 \mathrm{~b}$ & & & & & & & NO & 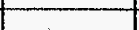 & & \\
\hline 384 & OXYBISII-CHLOROPROPANE), 2,2'- & & & & & & & & & & & & & \\
\hline 365 & PALLADUUM & $7440-05-3$ & & & & & & & & & & & & \\
\hline 386 & PARALDEHYOE & $123-63.7$ & ND & DOE 1990b & & & & & & & & & & \\
\hline $387 \mid$ & PAAATHION & $56 \cdot 38 \cdot 2$ & ND & DOE $1990 \mathrm{~b}$ & & & & & & & & & & \\
\hline 38 & PENTACHLOROBENZENE & $608-93-6$ & ND & DOE 1990b & & & & & & & NO & & & - \\
\hline 389 & PENTACHLOROETHANE & 76.01 .7 & ND & DOE 1990b & & & & & & & ND- & & & \\
\hline 390 & PENTACHLORONITHOBENZENE & $82 \cdot 68 \cdot 8$ & ND & DOE $1990 \mathrm{~b}$ & & & & & & & ND. & - & & \\
\hline 391 & PENTACHLOROPHENOL & 87.86 .5 & NO & DOE $1994 a$ & & & & & ND & & ND & & & \\
\hline 392 & PERCHLORATE & & NO & DOE 1990b & & & & & & & & & & \\
\hline 393 & PEACHLOROETHYLENE & $127-18 \cdot 4$ & ND & DOE $1990 \mathrm{~b}$ & & & & & & & ND & & & \\
\hline 394 & PHENACETIN & $62 \cdot 44 \cdot 2$ & NO & DOE 1990b & & & & & & & NO & & & \\
\hline 395 & PPENANTHRENE & $85 \cdot 01 \cdot 8$ & ND & \begin{tabular}{|l} 
DOE 1994a \\
\end{tabular} & & $1500 \mu \mathrm{g} / \mathrm{kg}$ & & & ND & & & & & \\
\hline 396 & PHENONOL & $108-95-2$ & ND & DOE 1994a & & & & & ND & & NO & & & \\
\hline 397 & PHENYLENEDIAMINE & $|25265-76-3|$ & ND & DOE 19906 & & & & & & & ND & & & \\
\hline 398 & PHENYLTHIOUREA & $103-85-5$ & ND & DOE i & & & & & & & & & & \\
\hline 399 & PHOSPHATE & $7601-54-9$ & ND & DOE $1990 \mathrm{~b}$ & & & & & & & ND & ND & ND & \\
\hline 400 & PHOSPHOAIC ACID & $7664-38-2$ & & & & & & & & & & & & \\
\hline 401 & PHOSPHORUS & $7723-14-0$ & & & & & & & & & & & & \\
\hline 402 & PHOSPHOAUS 32 & & & & & & & & & & & & & \\
\hline 403 & PHTHALIC ACIO ESTERS & & ND & DOE $1990 \mathrm{~b}$ & & & & & & & NO & & & \\
\hline 404 & FICOLINE, 2- & $109.06 \cdot 8$ & $\overline{N D}$ & DOE $1990 \mathrm{~b}$ & & & & & & & ND & & & \\
\hline 405 & PLUTONIUM 238 & $13981-16 \cdot 3$ & & & & $11 \mathrm{pCi} / \mathrm{g}$ & $0.047 \mathrm{pCi} / \mathrm{g}$ & & & & & & NO & $0.00115 \mathrm{pCi}$ \\
\hline 406 & PLUTONIUM 239 & $15117-48-3$ & & & $0.16 \mathrm{pCi} / \mathrm{g}$ & $230 \mathrm{pCi} / \mathrm{g}$ & ND & & & & & & IND & $0.071 \mathrm{pCi} / \mathrm{g}$ \\
\hline
\end{tabular}


Table A.2. (contd)

\begin{tabular}{|c|c|c|c|c|c|c|c|c|c|c|c|c|c|c|}
\hline - & & & & & & & & & Soll & & & & & IMENT \\
\hline-1 & Name of Analyte & |CAS" & Background(a) & $\begin{array}{l}\text { Backgorouna } \\
\text { Reference }\end{array}$ & 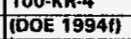 & $\begin{array}{l}\text { IOO-HA-1 } \\
\text { (DOE 1993C) }\end{array}$ & $\begin{array}{l}100-B C-1 \\
\text { (DOE 1994d) }\end{array}$ & $\left|\begin{array}{l}100-8 C-5 \\
(D O E\end{array}\right|$ & $100 \cdot \mathrm{N}$ (b) & $\frac{1100 \text { Artat }}{(\text { Law 1990) }}$ & $\frac{300-F F-1}{100 E-1990 b)}$ & \begin{tabular}{|l|}
$300 \cdot F F-5$ \\
(DOE 19900)
\end{tabular} & \begin{tabular}{|l|}
$300-F F-5$ \\
(DOE 1990a)
\end{tabular} & $\begin{array}{l}\text { 100 Arens } \\
\text { (Weiss 1993) }\end{array}$ \\
\hline (407) & PUTONIUM 240 & & & & & & & & & & & & & \\
\hline 408 & PLUTONIUM 241 & $\frac{14119.32 \cdot 5}{1419 \cdot 32 \cdot 6}$ & & & & (W/Pu239) & No & & & & & & & \\
\hline 409 & PLUTONIUM 242 & $13982-10-0$ & & & & & & & & & & & ND & \\
\hline 410 & POLONIUM 210 & $\frac{139881.52 \cdot 8}{139}$ & & & & & & & & & & & & -1 \\
\hline 411 & POLONIUM 212 & $15389-34.7$ & & & & & & & & & & & & $\ldots$ \\
\hline 412 & POLONIUM 216 & $15 \overline{7} \overline{6} \overline{6}-\overline{5} \overline{8}-8$ & & & & & & & & & & & & \\
\hline 413 & POLYCHLOOINATED BIPHENYLS & $1336-36-3$ & & & & & & & & & & & & \\
\hline 414 & POTASSIUM & $7447.40-7$ & $2676 \mathrm{mg} / \mathrm{kg}$ & DOE 1994a & $1360 \mathrm{mg} / \mathrm{kg}$ & $13000 \mathrm{pCi} / \mathrm{g}$ & $2130 \mathrm{mg} / \mathrm{kg}$ & & $T_{3}+x_{2}$ & & $1830 \mathrm{mg} / \mathrm{kg}$ & $4980 \mathrm{mg} / \mathrm{kg}$ & NO & $1900 \mathrm{mg} / \mathrm{kg}$ \\
\hline 415 & POTASSIUM 40 & & & & $16 \mathrm{pCi} / \mathrm{g}$ & $15 \mathrm{pCl} / \mathrm{g}$ & $13.86 \mathrm{pCi} / \mathrm{g}$ & & & & & ND & $15 \mathrm{pCi} / \mathrm{g}$ & $23 \mathrm{pCl} / \mathrm{g}$ \\
\hline 416 & POTASSIUM CHLOAATE & $3811.04-9$ & & & & & & & & & & & & \\
\hline 417 & POTASSIUM CYANIDE & 151.50 .8 & & & & & & & & & & & & \\
\hline 418 & POTASSIUM DICHROMATE & $7778 \cdot 50 \cdot 9$ & & & & & & & & & & & & \\
\hline 419 & POTASSIUM FLUOAIDE & $7789-23-3$ & & & & & & & & & & & & \\
\hline 420 & POTASSIUM HYDROXIDE & $1310.58-3$ & & & & & & & & & & & & \\
\hline 421 & POTASSIUM NITRATE & $7757-79-1$ & & & & & & & & & & & & \\
\hline 422 & POTASSIUM PERMANGANATE & $7722-64-7$ & & & & & & & & & & & & \\
\hline 423 & PAOMETHIUM 147 & $7440 \cdot 12 \cdot 2$ & & & & & & & & & & & & \\
\hline 424 & PAONAMIDE & $23950-58-5$ & No & DOE 1990̈ & & & 工 & & & & NND & & & \\
\hline 425 & PROPYN-1.01.2- & $107-19.7$ & ND & DOE 19900 & & & & & & & & & & \\
\hline 426 & PFOTACTINIUM 231 & $14331.85-2$ & & & & & & & & & & & & \\
\hline 427 & PROTACTINIUM 233 & $13981-14-1$ & & & & & & & & & & & & \\
\hline 428 & PYRENE & 129.00 .0 & No & DOE $1994 \mathrm{a}$ & & $1200 \mathrm{\mu g} / \mathrm{kg}$ & . & 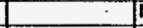 & ND & & & & & \\
\hline 429 & PYAIDINE & 170.86 .1 & IND & DOE 19906 & & & & & & & NO & & & \\
\hline 430 & FADIUM & 7440.14 .4 & & & & & & & & & & & NO & \\
\hline 431 & RADIUM 223 & & & & & & & & & & & & & \\
\hline 432 & RADIUM 226 & $13982-63-3$ & No & DOE 1990b & $0.53 \mathrm{pC} / \mathrm{g}$ & $0.85 \mathrm{pCi} / \mathrm{g}$ & $0.84 p \mathrm{Ci} / \mathrm{g}$ & & & & & $3.09 \mathrm{pCi} / \mathrm{g}$ & $.71 \mathrm{pCt} / \mathrm{G}$ & $1.7 \mathrm{pCi} / 9$ \\
\hline 433 & AADIUM 228 & & & & & & & & & & & & & \\
\hline 434 & BADON 220 & 22481.48 .7 & & & & & & & & & & & & \\
\hline 435 & AESERPINE & $50 \cdot 55-5$ & No & DOE 19906 & & & & & & & No & & & \\
\hline 436 & AESORCINOL & $108-46-3$ & ND & DOE 1990b & & & & & & & NO & & & \\
\hline 437 & AUTHENIUM 103 & $13968-53-1$ & & & & & No & & & & & No & & \\
\hline 438 & RUTHENIUM 106 & 13967.48 .1 & & & & & ND & & & & & IND & NO & IND \\
\hline 439 & SAFROL & $94-59-7$ & ND & DOE $1990 \mathrm{~b}$ & & & & 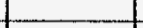 & & & No & & & \\
\hline 440 & SAMARIUM 151 & $15705 \cdot 94-3$ & & & & & & & & & & & & \\
\hline 441 & SCANDIUM 46 & & & & & & & & & & & & & \\
\hline$\overline{442}$ & SECBUTYL-4,6-DINITAOPHENOL & & & & & & & & & & & & & \\
\hline 443 & SEE ENIUM & 7782.49 .2 & No & DOE 1994a & & & $4.2 \mathrm{mg} / \mathrm{kg}$ & & & & NO & ND & ND & \\
\hline 444 & SELENIUM 79 & $15758.45 \cdot 9$ & & & & & & & & & & & & \\
\hline 445 & SELENIUM CHLORIDE & $10025-68.0$ & & & & & & & & & & & & \\
\hline 446 & SELENIUM NITRATE & & & & & & & & & & & & & \\
\hline 447 & SIIVER & 7440.22 .4 & $1.48 \mathrm{mg} / \mathrm{kg}$ & DOE 1994a & & & $1.9 \mathrm{mg} / \mathrm{kg}$ & & & & $18 \mathrm{mg} / \mathrm{kg}$ & & NO & $2.5 \mathrm{mg} / \mathrm{kg}$ \\
\hline 448 & SILVER CHLOHIOE & $7783-90.6$ & & & & & & & & & & $17300 \mathrm{me} / \mathrm{kg}$ & & \\
\hline 449 & $\begin{array}{l}\text { SILVEF NITRATE } \\
\text { SIIIVE OXIDE }\end{array}$ & 7761-88-8 & 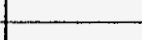 & & & & & & & & & & & \\
\hline $450 \mid$ & $\begin{array}{l}\text { SILVER OXIDE } \\
\text { SOOIUM }\end{array}$ & $\frac{2066-12-3}{7440-23 \cdot 5}$ & $969 \mathrm{mg} / \mathrm{kg}$ & DOE 1994a & $1770 \mathrm{mg} / \mathrm{kg}$ & & $779 \mathrm{mg} / \mathrm{kg}$ & & & & $401 \mathrm{mg} / \mathrm{kg}$ & & No & $\overline{920 \mathrm{mg} / \mathrm{kg}}$ \\
\hline $\mid \frac{4 b}{452}$ & SOOUM 22 & 7440.23 .5 & & & & NDD & & & & & & & & $0.13 \mathrm{pCl} / \mathrm{g}$ \\
\hline 453 & SODIUM ALUMINATE & & & & & & & & & & & & & \\
\hline 454 & SODIUM CHLORIDE & $7647.14 \cdot 5$ & & & & & & & & & & & I & \\
\hline 455 & SODIUM DICHAOMATE & $10588.01 \cdot 9$ & & & & & & & & & & & & \\
\hline 456 & SODIUM FLUŌRIDE & $7681-49-4$ & & & & & & & $\cdot$ & & & & & \\
\hline 457 & SODIUM HYOROXIDE & $1310 \cdot 73-2$ & & & & & & & & & & & & \\
\hline 458 & SODUM HYPOCHLORITE & $76 \frac{71.52-9}{7631.99-4}$ & & & & & & & & & & & & \\
\hline 459 & SODIUM NITRATE & $\mid \begin{array}{l}7631-99-4 \\
7601-54-9\end{array}$ & & & & & & & & & & & & \\
\hline$\frac{401}{461}$ & $\begin{array}{l}\text { SODIUM M SILICATE } \\
\end{array}$ & $1344 \cdot 09-8$ & & & & & & & & & & & & \\
\hline 462 & SODIUM SULFATE & $7757.82-6$ & & & & & & & & & & & & \\
\hline 463 & SOODIUM SULFIDE & $1313-82-2$ & & & & & & & & & & & & \\
\hline 464 & SODIUM THIOCYANATE & $540-72.7$ & & & & & & & & & & & & \\
\hline
\end{tabular}


Table A.2. (contd)

\begin{tabular}{|c|c|c|c|c|c|c|c|c|c|c|c|c|c|c|}
\hline & \multirow{2}{*}{\begin{tabular}{|l|} 
\\
Name of Analyto \\
\end{tabular}} & \multirow{2}{*}{ CAS \# } & \multirow{2}{*}{ Background(a) } & \multirow{2}{*}{\begin{tabular}{|l|} 
Background \\
Peferences
\end{tabular}} & \multirow[b]{2}{*}{\begin{tabular}{|l|} 
100-KA-4 \\
IDOE 1994h
\end{tabular}} & \multirow[b]{2}{*}{$\begin{array}{l}\text { 100-HA- - } \\
\text { (DOE 1993C) }\end{array}$} & \multirow{2}{*}{$\frac{100-B C-1}{(00 E \text { 1994d) }}$} & \multirow{3}{*}{\begin{tabular}{|l|}
$00-B C \cdot 5$ \\
$00 E$ 1993a) \\
\end{tabular}} & \multirow{2}{*}{$\frac{\text { SOIL }}{100-N(B)}$} & \multirow{2}{*}{ 1100 Area } & \multirow{2}{*}{$\begin{array}{l}\text { 300-FF-1 } \\
\text { (DOE 1990b) }\end{array}$} & & SEDII & MENT \\
\hline & & & & & & & & & & & & $300-F F-5$ & $300-$ FF.5 & 100 Areas \\
\hline & & & & & & & & & & & & & (DOE 1990a) & (Woiss 1993) \\
\hline 465 & STRONTIUM & $10476 \cdot 85 \cdot 4$ & & & & & & & & & $67 \mathrm{mg} / \mathrm{kg}$ & & & \\
\hline 466 & STRONTIUM 89 & $14158 \cdot 27 \cdot 1$ & & & & & & & & $\therefore$ & & & & \\
\hline 467 & STRONTIUM 90 & $10098 \cdot 97 \cdot 2$ & & & & $950 \mathrm{pCC} / \mathrm{g}$ & $770 \mathrm{pCi} / \mathrm{g}$ & & & & & ND & ND & $207 \mathrm{pCi} / \mathrm{g}$ \\
\hline 468 & STTRONTIUM CHLORIDE & $10476-85-4$ & & & $1 \mu \mathrm{g} / \mathrm{kg}$ & & & & & & & & & \\
\hline 469 & STAYCHNINE & $57-24.9$ & ND & DOE 1990b & & & & & & & ND & & & \\
\hline 470 & STYRENE & $100-42-6$ & ND & DOE 1994a & & & & & ND & & & NDD & ND & \\
\hline 471 & SULFATE & $12808 \cdot 79 \cdot 8$ & & & & & $32 \mathrm{mg} / \mathrm{kg}$ & & & & $52 \mathrm{mg} / \mathrm{kg}$ & $131 \mathrm{mg} / \mathrm{kg}$ & ND & \\
\hline \begin{tabular}{|c|c|}
472 \\
173
\end{tabular} & SULFIDE & $18496-25 \cdot 8$ & NO & DOE 1990b & & & & & & & & & & \\
\hline 473 & SULFUR OXIDES & $20901-21-7$ & & & & & & & & & & & & \\
\hline 474 & SULFUAIC ACID & 7664.93 .9 & ND & DOE $1990 \mathrm{~b}$ & & & & & & & & & & \\
\hline 475 & $T(2,4,4)$ & $7664-93.9$ & & & & & & & & & & & & \\
\hline 476 & SYM-TAINITROBENZENE & & ND & DOE 1990b & & & & & & & NDO & & & \\
\hline 477 & $T(2,4,5)$ & $93-76-5$ & & & & & & & & & INo & & & \\
\hline 478 & TECHNETIUM 99 & $14133-76-7$ & & & & $0.67 \mathrm{pCC} / \mathrm{g}$ & ND & & & & & & ND & $0.5 \mathrm{pCi} / 9$ \\
\hline 479 & 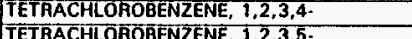 & & ND & DOE $1990 \mathrm{~b}$ & & & & & & & NO & & & \\
\hline $\begin{array}{ll}480 \\
81\end{array}$ & & & ND & DOE $1990 \mathrm{~b}$ & & & & & & & NDD & & & \\
\hline $\begin{array}{ll}481 \\
882\end{array}$ & 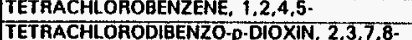 & $965-94-3$ & ND & DOE $1990 \mathrm{~b}$ & & & & & & & ND & & & \\
\hline 483 & TETRACHLOAOETHANE, $1,1,1,2-$ & $\frac{1.40 \cdot 01.0}{630.20 \cdot 6}$ & NO & DOE 1990b & & 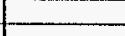 & 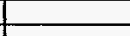 & & & & $t_{t=0}$ & & & \\
\hline 484 & TETRACHLOROETHANE, $1,1,2,2$ - & $79-34-5$ & ND & DOE 1994a & & & & & WO & & NDD & tNO & ND & \\
\hline 485 & TET RAETHYL PYROPHOSPHATE & $107 \cdot 49 \cdot 3$ & ND & DOE 1994a & & & & & & & & & & \\
\hline 486 & TETAACHLOAOETHYLENE & $127 \cdot 18-4$ & ND & DOE $1994 a$ & & & & & ND & & & tND & NDD & \\
\hline 487 & TETRACHLOHOMETHANE & $56 \cdot 23.5$ & & & & & & & & & & & & \\
\hline 488 & TETRAHYDROFURAN & $\begin{array}{ll}109.99 .9 \\
\end{array}$ & & & & & & & & & & & & \\
\hline 489 & THALLOUM & $7440-28-0$ & ND & DOE 1994a & & & ND & & & & ND & NO & ND & \\
\hline 490 & THALLIUM 208 & $14913-50.9$ & & & & & & & & & & & & \\
\hline 491 & THILFANOX & & ND & DOE 19900 & & & & & & & NO & 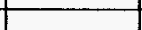 & & \\
\hline 492 & THTOUREA & $62 \cdot 56 \cdot 6$ & ND & DOE 1990b & & & & & & & & & & \\
\hline 493 & THIOUREA, $1 \cdot(0-$ CHLOAOPFHENYL)- & & ND & DOE 1990b & & & & & & & - & & & \\
\hline 494 & THIOUREA, 1-ACETYL-2. & & ND & DOE 1990b & & & & & & & & & & \\
\hline 495 & THIOUREA, 1-NAPHTHY-2- & & ND & DOE $1990 \mathrm{~b}$ & & & & & & & & & & \\
\hline 496 & THIRAM & 137-26-8 & ND & DOE 19906 & & & & & & & ND & & & \\
\hline 497 & THORIUM 228 & & & & & $0.95 \mathrm{pCi} / \mathrm{g}$ & $1.1 \mathrm{pCi} / \mathrm{g}$ & & & & & $1.61 \mathrm{pCi} / \mathrm{g}$ & $1.4 \mathrm{pCi}$ & $3 \mathrm{pCi} / \mathrm{g}$ \\
\hline \begin{tabular}{|c|}
498 \\
499 \\
\end{tabular} & $\begin{array}{l}\text { THOALIUM 229 } \\
\text { THOBUM 230 }\end{array}$ & \begin{tabular}{|l|}
$15595-54.4$ \\
14268.53 .7
\end{tabular} & & & & & & & & & & & & \\
\hline$\frac{499}{500}$ & $\begin{array}{l}\text { THORIUM } 230 \\
\text { THORIUM } 231\end{array}$ & 14268.63 .7 & & & & & & & & & & & & \\
\hline 501 & THORIUM 232 & & & & $1.1 \mu \mathrm{g} / \mathrm{kg}$ & $0.89 \mathrm{pCi} / \mathrm{g}$ & $0.8 \mathrm{pCi} / \mathrm{g}$ & & & & & $1.1 \mathrm{pCl} / \mathrm{g}$ & $1.1 \mathrm{pCi} / \mathrm{g}$ & $\frac{0.454 \mathrm{pC} / / 9}{3.2 \mathrm{pCi} / \mathrm{g}}$ \\
\hline 502 & THORIUM 234 & & & & & & & & & & & & & $0.812 \mathrm{pCi} / \mathrm{g}$ \\
\hline 503 & Tin & 7440.31 .5 & & & & & & & & & & & ND & \\
\hline 504 & TiN 113 & \begin{tabular}{|l|l|}
$13966 \cdot 06 \cdot 8$ \\
\end{tabular} & & & & & & & & & & & & \\
\hline 505 & TIN 126 & \begin{tabular}{|l|}
$58832-50-5$ \\
\end{tabular} & & & & & & & & & & & & \\
\hline 506 & TITANIUM & $7440 \cdot 32 \cdot 6$ & $2925 \mathrm{mg} / \mathrm{kg}$ & DOE 1994a & & & & & & & & & & \\
\hline 507 & TITANIUM CHLORIDE & $10049 \cdot 06-6$ & & & & & & & & & & & & \\
\hline 500 & TOLUENE & $108-88-3$ & ND & DOE 1994a & & $49 \mu \mathrm{g} / \mathrm{kg}$ & & & $350 \mathrm{mg} / \mathrm{kg}$ & & NO & NO & NO & \\
\hline 509 & TOLUEENEDIAMINE & $496-72-0$ & ND & DOE $1990 \mathrm{~b}$ & & & & & 5000 ingrag & & ND & & & \\
\hline 510 & TOLUIDINE HYDROCHLORIDE, 0 - & $636-21-5$ & ND & DOE 1990b & & & & & & & ND & & & \\
\hline 511 & TOTAL ORGANIC CAABON & & ND & DOE 1990b & & & & & & & & & & \\
\hline 512 & TOTAL ORGANIC HALIDE & & ND & DOE 1990b & & & & & & & & & & \\
\hline 513 & TOTAL PETROLEUM HYDROCA FBONS & & & & & & & & $125920 \mathrm{mg} / \mathrm{kg}$ & & & & & \\
\hline 514 & TOXAPHENE & $8001-35-2$ & ND & DOE 1994a & & & & & & & & & & \\
\hline 515 & IP(2,4,5)SILVEX & $93-72-1$ & ND & DOE $1990 \mathrm{~b}$ & & & & & & & & & & \\
\hline 516 & TRIBROMOMETHANE & $75-25-2$ & & & & & & & & & & & & \\
\hline 517 & TRABUTYL PHOSPHATE & $126 \cdot 73 \cdot 8$ & & & & & & & & & & & & \\
\hline 518 & TRIBOTYLPHOSPHORIC ACID & & ND & DOE $1990 \mathrm{~b}$ & & & & & & & ND & & & \\
\hline 519 & TAICHLOROBENZENE & & ND & DOE $1990 \mathrm{~b}$ & & & & & & & & & & \\
\hline 520 & TAICHLOROBENZENE, $1,2,3$ & 87.61 .6 & ND & DOE $1990 \mathrm{~b}$ & & & & & & & ND & & & 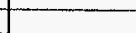 \\
\hline 521 & TAICHLORÖBENZENE, 1,2,4- & $120-82-1$ & ND & DOE 1994a & & & & & ND & & ND & & & \\
\hline 522 & THACHLOROBENZENE, $1,3,5$ - & $108 \cdot 70 \cdot 3$ & ND & DOE $1990 \mathrm{~b}$ & & & & & & & & & & \\
\hline
\end{tabular}


Table A.2. (contd)

\begin{tabular}{|c|c|c|c|c|c|c|c|c|c|c|c|c|c|c|}
\hline \multicolumn{2}{|c|}{1} & \multirow[b]{2}{*}{ CAS \# } & \multirow[b]{2}{*}{ Background(a) } & \multirow[b]{2}{*}{$\begin{array}{l}\text { Background } \\
\text { heferenco } \\
\end{array}$} & \multirow[b]{2}{*}{$\begin{array}{l}\text { 100-KA-4 } \\
\text { (DOE 1994h) }\end{array}$} & \multirow[b]{2}{*}{\begin{tabular}{|l} 
100-HA-1 \\
(DOE 1993a)
\end{tabular}} & \multirow[b]{2}{*}{\begin{tabular}{|l|}
$100-B C-1$ \\
$100 E$ 1994d \\
\end{tabular}} & \multirow[b]{2}{*}{\begin{tabular}{|l|}
$100-B C-5$ \\
$00 E$ 1993a)
\end{tabular}} & \multicolumn{4}{|c|}{$12001300 \mathrm{cos}$} & \multicolumn{2}{|c|}{ SEDIMENT } \\
\hline & Name of Analyto & & & & & & & & $100-\mathrm{N}(\mathrm{D})$ & \begin{tabular}{|l|}
1100 Area \\
Law 1990)
\end{tabular} & \begin{tabular}{|l|}
$300 \cdot F F \cdot 1$ \\
(DOE 19906)
\end{tabular} & \begin{tabular}{|l|l|}
$300 \cdot F F-5$ \\
$D O E$ 19900)
\end{tabular} & \begin{tabular}{|l|} 
300-FF-5 \\
$100 E$ 1990a)
\end{tabular} & \begin{tabular}{|l|}
100 Areas \\
Weiss 1993)
\end{tabular} \\
\hline & & & & & & & & & & & & & & \\
\hline $\mathbf{5} 2 \overline{3}$ & TRICHLOROETHANE, $1,1,1$ & $71 \cdot 55 \cdot 6$ & ND & DOE 2994a & & & & & ND & & ND & ND & ND & \\
\hline $5 \overline{24}$ & TAICHLOROETHANE, $1,1,2$ & $79.00-5$ & NDD & DOE 1994a & & & & & $\mathrm{ND}$ & & ND & ND & NDD & \\
\hline 525 & TRICHLOAOETHYLENE & 79.01 .6 & ND & DOE 1994a & & & ND & & ND & & ND & ND & ND & \\
\hline $5 \mathbf{2} \mathbf{6}$ & TAICHLOROMETHANETHIOL & $75-70-7$ & NDD & DOE 1990b & & & & & & & ND & & & \\
\hline 527 & TRICHLOROMONOFLUOROOMETHANE & $75-96-4$ & NO & DOE 1990b & & & & & & & ND & & & \\
\hline 528 & TRICHLOROPOPHENOL, 2,4,5- & $95-95-4$ & NO & DOE 1994a & & & & & ND & & NO & & & \\
\hline 529 & TRICHLOROPHENOL, 2,4,6- & 88-06-2 & NDO & DOE 1994a & & & & & ND & & ND & & & \\
\hline 530 & TAICHLOROPROPANE & $25735-29-9$ & ND & DOE 1990b & & & & & & & ND & & & \\
\hline $5 \overline{31}$ & TिICHLOROPAOPANE, $1,2,3-$ & 96.18 .4 & ND & DOE $1990 \mathrm{~b}$ & & & & & & & NO & & & \\
\hline$\overline{5} \overline{3} \overline{2}$ & TिIIETHYLPHOSPHOROTHIOATE, $0,0,0$. & $126-68 \cdot 1$ & ND & DOE 1990b & & & & & & & ND & & & \\
\hline $5 \overline{3} 3$ & IRIS (2,3 DIBROMOPROPHYL PHOSPHATE & \begin{tabular}{|l|l|}
126.72 .7 \\
\end{tabular} & ND & DOE $1990 \mathrm{~b}$ & & & & & & & NO & & & \\
\hline 534 & TRITIUM (HYODROGEN 3) & $10028-17-8$ & & & & $1600 \mathrm{pC} / / 9$ & ND & & & & & & & \\
\hline 535 & TUNGSTEN & $7440-33-7$ & & & & & & & & & & & & \\
\hline 536 & URANIUM & $7440-61-1$ & & & & & & & & & & & & \\
\hline 5̄37 & URANIUM (TOTAL ACTIVITY) & & & & & & & & & & & & ND & \\
\hline $5 \overline{3} 6$ & UUAANIUM 233 & $13968.55 \cdot 3$ & & & $0.59 \mathrm{pCi} / \mathrm{g}$ & $0.53 \mathrm{pC} / \mathrm{g}$ & $0.6 \mathrm{pC} / \mathrm{g}$ & & & & & $3.9 \mathrm{pCl} / \mathrm{g}$ & & $2.3 \mathrm{pCi} / \mathrm{g}$ \\
\hline 539 & UAANIUM 234 & $13966 \cdot 29 \cdot 5$ & & & $(w / 1 / 233)$ & & (w/U233) & & & & & wN233 & $3.9 \mathrm{pCi} / \mathrm{g}$ & w/u233 \\
\hline 540 & URANIUM 235 & $18117-96 \cdot 1$ & & & & $0.0016 \mathrm{pCi} / \mathrm{g}$ & $0.02 \mathrm{pCl} / \mathrm{g}$ & & & & & $0.23 \mathrm{pCi} / \mathrm{g}$ & ND & $0.1 . \mathrm{pC} / \mathrm{g}$ \\
\hline $5 \overline{41}$ & ÜAANIUM 236 & $13982.70-2$ & & & & & & & & & & & & \\
\hline 542 & UAANIUM 238 & 24678-82-8 & & & $0.59 \mathrm{pCi} / \mathrm{g}$ & $4.7 \mathrm{pCl} / 9$ & $0.62 \mathrm{pCl} / \mathrm{g}$ & & & & & $3.2 \mathrm{pCi} / 9$ & $3.2 \mathrm{pCi} / 9$ & $2.3 \mathrm{pCi} / 9$ \\
\hline 543 & VĀNADDIUM & $7440-62 \cdot 2$ & $96.7 \mathrm{mg} / \mathrm{kg}$ & DOE 1994a & $55.8 \mathrm{mg} / \mathrm{kg}$ & $389 \mathrm{mg} / \mathrm{kg}$ & $76.9 \mathrm{mg} / \mathrm{kg}$ & & & & $73 \mathrm{mg} / \mathrm{kg}$ & NO & $44.4 \mathrm{mg} / \mathrm{kg}$ & $82.2 \mathrm{mg} / \mathrm{kg}$ \\
\hline 544 & VANADIUM PENTOXIDE & $13140-62.1$ & & & & & & & & & & & & \\
\hline 545 & VINYL ACETATE & $108.05 \cdot 4$ & NO & DOE 1994a & & & & & NO & & & NO & NO & \\
\hline $5 \overline{46}$ & VINYL CHLORIDE & $75-01-4$ & ND & DOE 1994a & & & & & ND & & NDO & ND & ND & \\
\hline 547 & WARFAAIN & $81-81-2$ & ND & DOE 1990b & & & & & & & ND & & & \\
\hline 548 & XYLEENE & $1330-20-7$ & NO & DOE 1994a & & & & & $1800 \mathrm{mg} / \mathrm{kg}$ & & & ND & ND & \\
\hline $5 \overline{49}$ & XYLENE, $m$ & $108 \cdot 38-3$ & ND & DOE $1990 \mathrm{~b}$ & & & & & & & ND & & & \\
\hline E550 & XYLENE. O.P. & & ND & DOE $1990 \mathrm{~b}$ & & & & & & & NDD & & & \\
\hline 550 & YิTีคIUM 90 & $10098-91-6$ & & & & & & & & & & & & \\
\hline 552 & $\operatorname{ZinC}$ & $7440-66-6$ & $74.7 \mathrm{mg} / \mathrm{kg}$ & DOE 1994a & $24.3 \mathrm{mg} / \mathrm{kg}$ & $520 \mathrm{mg} / \mathrm{kg}$ & $309 \mathrm{mg} / \mathrm{kg}$ & & & & $97 \mathrm{mg} / \mathrm{kg}$ & $70.7 \mathrm{mg} / \mathrm{kg}$ & $11 \overline{\mathrm{mg} / \mathrm{kg}}$ & $397 \mathrm{mg} / \mathrm{kg}$ \\
\hline $5 \overline{5} \overline{3}$ & Ziñ 65 & $13982 \cdot 39-3$ & & & & & No & & & & & ND & NO & $0.24 \mathrm{pCl} / \mathrm{g}$ \\
\hline 554 & ZINC AMALGAM & & & & & & & & & & & & & \\
\hline$\overline{\mathbf{5}} \overline{55}$ & ZINC CHLÖRIOE & $1646.85 \cdot 7$ & & & & & & & & & & & & \\
\hline $55 \overline{6}$ & ZINTC COMPOUNOS & $7646-85-7$ & & & & & & & & & & & & \\
\hline 557 & ZINC NITRATE & $77799-88.6$ & & & & & & & & & & & & \\
\hline 558 & ZIRCONIUM & $7440-67.7$ & $45.4 \mathrm{mg} / \mathrm{kg}$ & DOE 1994a & & & & & & & & & & \\
\hline 559 & ZiRCONIUM 93 & 15751.77 .6 & & & & & & & & & & & & \\
\hline 560 & ZIACONIUM 95 & \begin{tabular}{|l|}
$13967.71-0$ \\
\end{tabular} & & & & $0.56 \mathrm{pCi} / \mathrm{g}$ & ND & & & & & ND & & \\
\hline (a) & Provisional values estimated to be the back & und concentrat & tions. & & & & & & & & & & & \\
\hline (ib) & Hartman and Lindsey (1993); Rowley 1993. & & & & & & & & & & & & & \\
\hline
\end{tabular}


Table A.3. Maximum Detected Concentrations in Groundwater in the Hanford Site 100, 200, and 600 Areas Away from the Columbia River, 1980-1994

\begin{tabular}{|c|c|c|}
\hline & Number & \\
\hline Name of Analyte & of Plumes & Concentration \\
\hline \multicolumn{3}{|l|}{100 Areas } \\
\hline Chromium $(+6)$ & 3 & $1.570 \mathrm{ppb}$ \\
\hline Nitrate & 10 & $130,000 \mathrm{ppb}$ \\
\hline Strontium-90 & 8 & $1,800 \mathrm{pCi} / \mathrm{L}$ \\
\hline Tritium (Hydrogen-3) & 4 & $80,000 \mathrm{pCi} / \mathrm{L}$ \\
\hline \multicolumn{3}{|l|}{200 West Area } \\
\hline Arsenic & 4 & $24 \mathrm{ppb}$ \\
\hline Carbon Tetrachloride & 1 & $6,559 \mathrm{ppb}$ \\
\hline Chloroform & 2 & $1,595 \mathrm{ppb}$ \\
\hline Chromium & 5 & $323 \mathrm{ppb}$ \\
\hline Fluoride & 3 & $10,067 \mathrm{ppb}$ \\
\hline lodine-129 & 2 & $30 \mathrm{pCi} / \mathrm{L}$ \\
\hline Nitrate & 5 & $1,322,000 \mathrm{ppb}$ \\
\hline Technetium-99 & 5 & $26,602 \mathrm{pCi} / \mathrm{L}$ \\
\hline Trichloroethylene & 3 & $32 \mathrm{ppb}$ \\
\hline Tritium (Hydrogen-3) & 3 & $6,193,000 \mathrm{pCi} / \mathrm{L}$ \\
\hline Uranium & 4 & $1,616 \mathrm{pCi} / \mathrm{L}$ \\
\hline \multicolumn{3}{|l|}{200 East Area } \\
\hline Arsenic & 4 & 24ppb \\
\hline Cesium-137 & 1 & $1,326 \mathrm{pCi} / \mathrm{L}$ \\
\hline Chloroform & 1 & $7 \mathrm{ppb}$ \\
\hline Chromium & 4 & $288 \mathrm{ppb}$ \\
\hline Cobalt- 60 & 2 & $440 \mathrm{pCi} / \mathrm{L}$ \\
\hline Cyanide & 2 & $893 \mathrm{ppb}$ \\
\hline lodine-129 & 3 & $20 \mathrm{pCi} / \mathrm{L}$ \\
\hline Nitrate & 7 & $397,000 \mathrm{ppb}$ \\
\hline Plutonium-239/240 & 1 & $69 \mathrm{pCi} / \mathrm{L}$ \\
\hline Strontium-90 & 5 & $5,149 \mathrm{pCi} / \mathrm{L}$ \\
\hline Technetium-99 & 2 & $22,163 \mathrm{pCi} / \mathrm{L}$ \\
\hline Tritium (Hydrogen-3) & 5 & $4,126,000 \mathrm{pCi} / \mathrm{L}$ \\
\hline Uranium & 1 & $27 \mathrm{pCi} / \mathrm{L}$ \\
\hline \multicolumn{3}{|c|}{600 Area (Solid Waste Landfill Site) } \\
\hline Chloroform & 1 & $0.5 \mathrm{ppb}$ \\
\hline Dichloroethane, 1, 1- & 1 & $7 \mathrm{ppb}$ \\
\hline Tetrachloroethene & 1 & $12 \mathrm{ppb}$ \\
\hline Trichloroethane, $1,1,1-$ & 1 & $50 \mathrm{ppb}$ \\
\hline Trichloroethene & 1 & $7 \mathrm{ppb}$ \\
\hline
\end{tabular}


Appendix B

Parameter Values Used in Screening Analyses 


\section{Appendix B}

\section{Parameter Values Used in Screening Analyses}

The equations detailed in Section 4.0 require parameters for each radionuclide and chemical evaluated. The parameters used to screen samples from the Columbia River and groundwater within 150 meters (500 feet) of the Columbia River are provided in Table B.1. The parameters used to screen samples of soil and sediment are provided in Table B.2. The parameters used to screen samples of groundwater farther than 150 meters (500) feet from the Columbia River are provided in Table B.3.

The following abbreviations are used in the tables:

LC50 = lowest concentration reported to be lethal to aquatic life, as reported in EPA 1985.

$\mathrm{RfD}=\mathrm{EPA}$ chronic oral reference dose value.

TLM = lowest concentration below which no effects on aquatic life are observed, as reported in EPA 1985. 
Table B.1. Parameters Used to Screen Columbia River and Groundwater Near the Columbia River

\begin{tabular}{|c|c|c|c|c|c|c|c|c|c|c|c|c|}
\hline & & & & Ingesstion & External & & Cancer & Fish & & & Notes on & Watar Quality \\
\hline & & \multicolumn{2}{|c|}{ Maximum Concentration in } & Slopa Factor & Slope Factor & RfD & Potency Factor & Bloaccumulation & LC50 & TLM & Fish & Criteria \\
\hline & Name of Analyte & Surlace Water & Groundwater & (Risk/pCi) & (Risk/pCi) & $(\mathrm{mg} / \mathrm{kg} / \mathrm{day})$ & (1)/(mg/kg/day) & $\mathbf{I L / k g l}$ & $(\mu \mathrm{g} / \mathrm{L})$ & $\left(\omega_{0} / L\right)$ & Toxicity & $\psi(\mu / L)$ \\
\hline & & & & & & & & & & & & \\
\hline 1 & ACETONE & $11 \mu \mathrm{g} / \mathrm{L}$ & $30 \mu \mathrm{g} / \mathrm{h}$ & & & 0.1 & & 0.2 & & $4,000,000$ & & \\
\hline 2 & ALUMINUM & & $4.810 \mu \mathrm{g} /$ & & & 0.0004 & & 10 & 5,000 & & 8 & \\
\hline 3 & AMERICIUM 241 & & $0.021 \mathrm{pCi} / \mathrm{L}$ & $2.40 E-10$ & 4.90E-09 & & & 250 & & & & \\
\hline 4 & AMMONIA & & $70 \mathrm{\mu g} / \mathrm{L}$ & & & 0.029 & & 0.2 & 1,800 & & $s$ ammoniur & \\
\hline 5 & AMMONIUM & & $1.630 \mathrm{\mu g} / \mathrm{L}$ & & & 0.09 & & 0.2 & & 1,800 & 9 & \\
\hline 6 & ANTIMONY & & $60 \mu \mathrm{g} / \mathrm{L}$ & & & 0.0004 & & 200 & & & & \\
\hline 기 & ANTIMONY 125 & & $20 \mathrm{pC} / \mathrm{L}$ & $8.40 E-13$ & $1.20 E-06$ & & & 200 & & & & \\
\hline 8 & AASENIC & $3.4 \mu \mathrm{gh}$ & $17 \mu \mathrm{g} / \mathrm{L}$ & & & 0.0003 & 1.75 & .100 & 1.100 & & & 190 \\
\hline 9 & BAaIUM & $48.2 \mu 9 / 2$ & $719 \mu \mathrm{gg} / \mathrm{L}$ & & & 0.07 & & 200 & 400,000 & & & : \\
\hline 10 & BERYLLUM & & $6 \mu \mathrm{g} / \mathrm{L}$ & & & 0.005 & 4.3 & 19 & 200 & & & \\
\hline 11 & BEAYLLIUM 7 & & & & & & & & & & 10 & \\
\hline 12 & BIS(2-ETHYLHEXYL) PHTHALAT & & $50 \mathrm{\mu g} / \mathrm{h}$ & & & 0.02 & 0.014 & 70 & & 32,000 & & \\
\hline 13 & BISMUTH & & & & & & & & & & 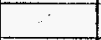 & \\
\hline 14 & BORON & & $64 \mu \mathrm{g} / \mathrm{L}$ & & & 0.09 & & & & & & \\
\hline 15 & CADMIUM & & $31 \mu g / L$ & & & 0.0005 & 6.3 & 200 & & 30,000 & & 1.1 \\
\hline 16 & CALCIUM & $35.900 \mu 9 \mathrm{~L}$ & $302,000 \mu \mathrm{g} / \mathrm{h}$ & & & & & & & & & \\
\hline 17 & CARBON 14 & & $23.000 \mathrm{pCi} / \mathrm{L}$ & $9.00 E-13$ & 0 & & & 4600 & & & & \\
\hline 18 & CESIUM 134 & $0.012 \mathrm{pCin}$ & & $4.10 E-11$ & $5.20 E-06$ & & & 2000 & & & & \\
\hline 19 & CESIUM 137 & $0.13 \mathrm{pcin}$ & $0.5 \mathrm{pCl/2}$ & $2.80 E-11$ & $2.00 E-06$ & & & 2000 & & & & \\
\hline 20 & CHLORIDE & $870 \mu \mathrm{g} / \mathrm{L}$ & $122.000 \mathrm{\mu g} / \mathrm{L}$ & & & & & 50 & & & & \\
\hline 21 & CHLOROFORM & & $42 \mu \mathrm{gg}$ & & & 0.01 & 0.006 & 100 & 100,000 & & & \\
\hline 22 & CHAOMIUM & $22 \mu \mathrm{g} / \mathrm{L}$ & $1,950 \mu \mu_{0} / 4$ & & & 1 & 41 & 200 & 1,000 & & & 11 \\
\hline 23 & COBALT & & $8 \mu \mathrm{g} / \mathrm{L}$ & & & 0.0081 & & 50 & & $10,000,000$ & & \\
\hline 24 & COBALT 60 & $0.011 \mathrm{pCin}$ & $140 \mathrm{pCi} / \mathrm{L}$ & $1.50 E-11$ & $8.60 \mathrm{E}-06$ & & & 330 & & & & \\
\hline 25 & COPPER & $22 \mu 9 h$ & $516 \mu \mathrm{g} / \mathrm{L}$ & & & 0.0003 & & 50 & 500 & & & 12 \\
\hline 26 & CYANIDE & & $21.1 \mu \mathrm{g} / \mathrm{L}$ & & & 0.02 & & 0.2 & & & & 5.2 \\
\hline 27. & DICHLOROETHYLENE, 1.2- & & $200 \mu \mathrm{g} / \mathrm{L}$ & & & & 0.009 & 2.9 & & 5000 & & \\
\hline 28 & DICHLOROETHYLENE, 1,2-trans & & $130 \mu \mathrm{g} / \mathrm{L}$ & & & 0.02 & 1.2 & 20 & & & & \\
\hline 29 & EUROPIUM 154 & & $2 \mathrm{pCiM}$ & $3.00 E-12$ & $4.10 \mathrm{E}-06$ & & & 25 & & & & \\
\hline 30 & FLUORIDE & $150 \mathrm{\mu g} / \mathrm{L}$ & $2.080 \mu \mathrm{\mu g}$ & & & 0.06 & & 10 & & 2,300 & 11 & \\
\hline 31 & HYDRAZINE & & $7 \mu \mathrm{g} /$ & & & & 3 & 0.5 & & 2,000 & & \\
\hline 32 & IODINE 129 & $0.16 \mathrm{pCi}$ & & $1.90 \mathrm{E}-10$ & 4.10E-09 & & & 16 & & & & \\
\hline 33 & IRON & $463 \mathrm{pCi} / \mathrm{L}$ & $37.300 \mu 9 / 2$ & & & 1.3 & & 2000 & & & & \\
\hline 34 & LEAD & & $173 \mu \mathrm{g} / \mathrm{L}$ & & & 0.0014 & & 100 & & 530 & & 3.2 \\
\hline 35 & LITHIIUM & & & & & & & & & & & \\
\hline 36 & MAGNESIUM & $9,860 \mathrm{~kg} / \mathrm{L}$ & $55,000 \mu 9 / 2$ & & & 50 & & 50 & & & & \\
\hline 37 & MANGANESE & $22.8 \mu \mathrm{g} / \mathrm{L}$ & $400 \mu \mathrm{g} / \mathrm{L}$ & & & 0.07 & & 400 & & 500,000 & 12 & \\
\hline 38 & MERCURY & & $8.9 \mu \mathrm{g} / \mathrm{L}$ & & & 0.0003 & & 1000 & 10 & & & 0.012 \\
\hline 39 & METHYL ETHYL KETONE & & $18 \mu \mathrm{g} / \mathrm{L}$ & & & 1 & & 50 & $5,600,000$ & & & \\
\hline 40 & METHYLENE CHLORIDE & & $3,040 \mu \mathrm{g} / \mathrm{L}$ & & & 0.06 & 0.0075 & 2.5 & 550,000 & & 13 & \\
\hline 41 & NICKEL & $31 \mu \mathrm{g} / \mathrm{L}$ & $479 \mu \mathrm{g} / \mathrm{L}$ & & & 0.02 & & 100 & & 380 & & 160 \\
\hline
\end{tabular}




\begin{tabular}{|c|c|c|c|c|c|c|c|c|c|c|c|c|}
\hline & & & & & & & & & & & opplxosugd Un!peven $L$ & \\
\hline & & & & & & & & & शueपrowosolug & $\varepsilon 1$ & s\&zn 9 & 9 \\
\hline & & & & & $\because$ & & & & ts esauebuew & 21 & op!xolp un!uen! $/ 9$ & $\mathrm{~s}$ \\
\hline & & & & & & & & & Eutgonly aunsse & II & Injins to & 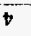 \\
\hline & & & & & & & & & Un!IIIJeq ounsse & 01 & 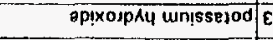 & $\varepsilon$ \\
\hline & & & & & & & & sp!xo & ojpky wintuoumue & 6 & epos 10 gleydsoyd $/ 2$ & $z$ \\
\hline & & & & & & & & & 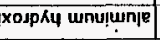 & 8 & 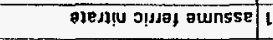 & 1 \\
\hline & & & & & & & & & & 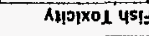 & SOloN & \\
\hline & & & & & & & & & & & & \\
\hline 001 & & & oEt & 0092 & & E.0 & & & $7 / B+008^{\prime} 8$ & $7 / 6 n a$ & JNIZ E & $\varepsilon L$ \\
\hline & & $000^{\prime} t$ & & ogt & & $z$ & & & & vert & 3 NG91 $1 \times$ & $Z L$ \\
\hline & 2 & $000^{\prime} 99$ & & & & & & & 7 tor ob & & WกIOYNYA I & KL \\
\hline & & & & os & & & $11-9012$ & $11 \cdot 309 \cdot 1$ & $7 ! 10086$ & $7 ! 0 d 61$ & BEZ WกINYHก] 0 & $0<$ \\
\hline & & & & os & & & $\angle 0-30+2$ & $11 \cdot 309 \cdot 1$ & $71 ! 00<1$ & $7110^{d} 100$ & $\begin{array}{l}\text { SEZ WחINYGก } \\
\end{array}$ & 69 \\
\hline & 9 & & & og & & & $11-300 \varepsilon$ & $11-309 \cdot 1$ & $7110 d 021$ & $7 / 12081$ & tEZ WกINYYก 8 & 89 \\
\hline & 9 & & & os & & & $11-302 \cdot t$ & $11-309 !$ & $710^{d} \varepsilon \varepsilon$ & & EEZ WกINYEก $/ 2$ & $\angle 9$ \\
\hline & & & - & 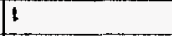 & & & 0 & $t 1 \cdot 300 t \cdot 9$ & $71100^{\circ} 000^{\circ} 006^{\circ}$ & $7 / 0^{0} 0 \varepsilon t^{\prime} t$ & (E NaDOYOXH) WNIIHI $]$ & 99 \\
\hline & & & $000^{\prime} 99$ & at & 110.0 & & & & $7 / \theta \pi \mid \square z$ & & 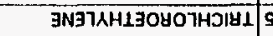 & $\mathbf{9 9}$ \\
\hline & & & 00009 & os & & 20 & & & $7 / B d 62$ & $\bar{v} 6 f^{\prime} L t b$ & 3Nヨnา01 & $\$ 9$ \\
\hline & 9 & & reypows IIIM & & & & & & & & WกINYIIIE & E9 \\
\hline & & & & 001 & & & $11 \cdot 3092$ & $1 t-302 \cdot 1$ & $7 / 20 d s t$ & & ZEะ WกIYOHI & 29 \\
\hline & & & & 001 & & & 90-399'9 & $11.309 \cdot 9$ & $7 / 10 d \bar{E}$ & & 822 Wก18OH1 1 & 19 \\
\hline & & & ot & 00001 & & & & & $7 / 6 \mathrm{Ht}$ & & Wก1778H1 0 & 09 \\
\hline & & & 00081 & 001 & 1500 & & & & $7 / 6{ }^{6} 6 \varepsilon$ & & 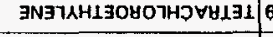 & 69 \\
\hline & & & & 91 & & & $\varepsilon 1-300 \cdot 9$ & $21-30 E^{\prime} t$ & T/100 0L2'z & & 66 WחILINHJ3I & 89 \\
\hline & $t$ & $000^{\prime} 08$ & & & & & & & $7 E \sigma H^{\prime} 000^{\prime} \mathrm{E}$ & & 30147ns & $\angle 9$ \\
\hline & $t$ & $000^{\prime} 08$ & & OGL & & ic & & & $7 / 8 r 000^{\prime} 009$ & $7 / 6+009.8$ & 3IVงากS: & 99 \\
\hline & & & & os & & & 0 & $11-30 \varepsilon \varepsilon$ & $7 ! 5000008$ & $7 ! \Omega^{d} \theta \bar{c}$ & 06 WNILNOHIS S & 59 \\
\hline & & $1000^{\prime} 00 z$ & & 09 & & 90 & & & $7 / 8 n 01 \varepsilon$ & & WNIINOUIS & ts \\
\hline & & $000^{\circ} 02 L^{\prime} \mathrm{t}$ & & 001 & & $00 \varepsilon$ & & & $7^{6 / 6 r} 000^{\prime} 002$ & 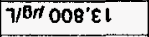 & Wnioos & $\varepsilon 9$ \\
\hline & & & $t$ & & & 9000 & & & $7 / 6+61$ & & $8 \exists \wedge 715$ & $z \mathrm{~s}$ \\
\hline & & & & & & & & & & & NOJ171 & 19 \\
\hline 9 & & oog' $z$ & & $0<1$ & & $500^{\prime} 0$ & & & $7 / 6 n z<4$ & & WNIN379s & og \\
\hline & & & & 001 & & & $\angle 0-30 \angle \cdot 9$ & 21 -309'6 & $7 / 10 d t b \varepsilon$ & & $0+901$ WNINבHINY & 60 \\
\hline & & & & oL & & & $80 \cdot 302 \cdot 1$ & $01-30 z^{\prime} 1$ & $7 / \partial^{d} \varepsilon^{\circ} 0$ & & $9 z z$ wnlavy & 80 \\
\hline & $\varepsilon$ & & $000^{\prime} 08$ & 0001 & & o:s & & & $7 / B H^{\prime \prime}$ OOE'LI & 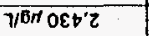 & Wniss & $\angle t$ \\
\hline & & & & 1092 & & & $11-302$. & $01-30 E^{\prime} Z$ & $7 / 10^{0} 80^{\circ} 0$ & & 6EZ WnINOInTd & 90 \\
\hline & & & & 09 & & & $11-3082$ & $01-\exists 02 \cdot 2$ & $7 / 12 \mathrm{~d} 10 \%$ & & 8E2 WกINOInTd & st \\
\hline & 2 & 00069 & & 00002 & & 980 & & & $\overline{1 / \theta \pi} 0 z^{\prime} \varepsilon$ & & تLVHdSOHd & $t$ \\
\hline & \begin{tabular}{|l|} 
eve \\
\end{tabular} & & $000^{\prime} 0 z$ & 000091 & & tEo.o & & & $7 / 6 n 000.09$ & & BLIYIN & Et \\
\hline & $t$ & & $000^{\prime} 0 z$ & 000051 & & 9.1 & & & $7 / 8 \pi 000^{\prime} 06$ & $7^{1 / 6 r} 08 \mathrm{p}$ & 3IVYLIN & $2 t$ \\
\hline & & & & & & & & & & & & \\
\hline $17 / 6 m$ & A $2 \geq 9 ? \times 01$ & $178 m$ & $(7 / \theta+n)$ & $(9 x / 7)$ & $($ (Kepp/6n/(6u)/(t) & 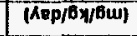 & IDd/2) & 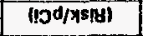 & 1018 mpunosg & 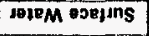 & 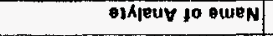 & \\
\hline อบ1 & $45 !$ & W71 & 0907 & Uope|numsovolg & $10100, \mathrm{~A}$ Kove10d & OB甘 & J0190y odols & 10150日 odo/s & uf Hopestuesu & oj wnupkew & & \\
\hline All|eno nejeM & 110 selon & & & 4\$1 & ABJuES & & Furaikg & HoppabuY & & & & \\
\hline
\end{tabular}

(p)uos) ' $\mathbf{I}^{\cdot} \mathbf{g}$ әрqष $\mathbf{L}$ 
Table B.2. Parameters Used to Screen Soil and Sediment

\begin{tabular}{|c|c|c|c|c|c|c|c|c|c|c|c|c|}
\hline & & & & \multirow{3}{*}{$\begin{array}{c}\text { Ingestion } \\
\text { Slope Factor } \\
\text { (Alsk/pCI) } \\
\end{array}$} & \multirow{3}{*}{\begin{tabular}{|c|} 
External \\
Slope Factor \\
(Pisk/pCi) \\
\end{tabular}} & \multirow{3}{*}{$\frac{\text { RiD }}{\text { (mg } / \mathrm{kg} / \mathrm{day})}$} & \multirow{3}{*}{$\begin{array}{c}\text { Cancer } \\
\text { Potency Factor } \\
\text { (1)/(mg/kg/day }) \\
\end{array}$} & \multirow{3}{*}{\begin{tabular}{|c|} 
Fish \\
Bloaccumulation \\
$11 / \mathrm{kg})$ \\
\end{tabular}} & \multirow{3}{*}{$\begin{array}{l}\text { LC5O } \\
\left.\omega_{g} / L\right) \\
\end{array}$} & \multirow{3}{*}{$\frac{\mathrm{TLM}}{(\mu \mathrm{g} / \mathrm{L})}$} & \multirow{3}{*}{\begin{tabular}{|c|} 
Notes on \\
Fish \\
Toxicity \\
\end{tabular}} & \multirow{3}{*}{$\begin{array}{c}\text { Watar Quality } \\
\text { Criteria } \\
\text { (ug/L) }\end{array}$} \\
\hline \multirow{2}{*}{\multicolumn{2}{|c|}{ Name of Analyte }} & \multicolumn{2}{|c|}{ Maximum Concentration in } & & & & & & & & & \\
\hline & & Soll & Sediment & & & & & & & & & \\
\hline & & & & & & & & & & & & \\
\hline & Radionuclldes & & & & & & & & & & & \\
\hline 1 & AMERICIUM 241 & $34 \mathrm{pCi} / \mathrm{g}$ & & $2.40 \mathrm{E}-10$ & $4.90 E \cdot 09$ & & & 250 & & & & \\
\hline 2 & ANTIMONY 124 & & $1.2 \mathrm{pCi} / \mathrm{g}$ & $2.90 \mathrm{E}-12$ & $6.50 E-06$ & & & 200 & & & & \\
\hline 3 & CARBON 14 & $34 \mathrm{pCi} / \mathrm{g}$ & & $9.00 E-13$ & 0 & & & 4,600 & & & & \\
\hline 4 & CESIUM 134 & $0.04 \mathrm{pCl} / \mathrm{g}$ & $0.29 \mathrm{pCl} / \mathrm{g}$ & 4.10E-11 & $5.20 \mathrm{E}-06$ & & & 2,000 & & & & \\
\hline 5 & CESIUM 137 & $2.900 \mathrm{pCi} / 9$ & $6 \mathrm{pCl} / \mathrm{g}$ & $2.80 E-11$ & $2.00 \mathrm{E}-06$ & & & 2,000 & & & & \\
\hline 6 & COBALT 60 & $18,000 \mathrm{pCi} / \mathrm{g}$ & $4.9 \mathrm{pCi} / 9$ & $1.50 \mathrm{E}-11$ & $8.60 \mathrm{E}-06$ & & & 330 & & & & . \\
\hline 7 & EUROPIUM 152 & $59,000 \mathrm{pC} / 9$ & $2.41 \mathrm{pCi} / \mathrm{g}$ & $2.10 \mathrm{E}-12$ & $3.60 E-06$ & & & 25 & & & & \\
\hline 8 & EUROPIUM 154 & $20,000 \mathrm{pCi} / \mathrm{g}$ & $0.24 \rho \mathrm{Ci} / \mathrm{g}$ & $3.00 \mathrm{E}-12$ & 4.10E-06 & & & 25 & & & & \\
\hline 9 & EUROPIUM 155 & $6,200 \mathrm{pC} 1 / \mathrm{g}$ & $0.32 \mathrm{pCi} / \mathrm{g}$ & 4.50E-13 & B.90E-08 & & & 25 & & & & \\
\hline 10 & NEPTUNIUM 237 & & $0.606 \mathrm{pCi} / \mathrm{g}$ & $2.20 \mathrm{E}-10$ & $7.80 E-09$ & & & 250 & & & & \\
\hline 11 & NICKEL 63 & $20.000 \mathrm{pC} / \mathrm{g}$ & & $2.40 E-13$ & of & & & 100 & & & & \\
\hline 12 & PLUTONIUM 238 & $11 \mathrm{pC} / \mathrm{g}$ & $0.00115 \mathrm{pCl} / \mathrm{g}$ & $2.20 \mathrm{E}-10$ & $2.80 E-11$ & & & 250 & & & & \\
\hline 13 & PLUTONIUM 239 & $230 \mathrm{pCi} / \mathrm{g}$ & $0.071 \mathrm{pCi} / \mathrm{g}$ & $2.30 E \cdot 10$ & 1.70E-11 & & & 250 & & & & \\
\hline 14 & PLUTOMIUM 240 & (w/Pu239) & & $2.30 E-10$ & 2.70E-11 & & & 250 & & & & \\
\hline 15 & POTASSIUM 40 & $16 \mathrm{pC} / \mathrm{g}$ & $23 \rho \mathrm{C} / \mathrm{g}$ & 1.10E-11 & 5.40E-07 & & & 1,000 & & & & \\
\hline 16 & RADIUM 226 & $3.09 \mathrm{pC} / \mathrm{g}$ & $1.7 \mathrm{pCl} / \mathrm{g}$ & $1.20 E-10$ & $1.20 \mathrm{E}-08$ & & & 20 & & & & \\
\hline 17 & STRONTIUM 90 & $960 \mathrm{pCl} / \mathrm{g}$ & $207 \mathrm{pCl} / 9$ & $3.30 \mathrm{E}-11$ & of & & & 50 & & & & \\
\hline 18 & TECHINETIUM 99 & $0.67 \mathrm{pC} / \mathrm{d}$ & $0.5 \mathrm{pCi} / \mathrm{g}$ & $1.30 E-12$ & 6.00E-13 & & & 15 & & & & \\
\hline 19 & THORIUM 228 & $1.61 \mathrm{pC} / \mathrm{g}$ & $3 \mathrm{pCilg}$ & 1.10E-11 & $5.50 E-10$ & & & 100 & & & & \\
\hline 20 & THORIUM 232 & $1.1 \mathrm{pC} / / \mathrm{g}$ & $3.2 \mathrm{pCi} / \mathrm{g}$ & $1.20 E-11$ & $2.60 E-11$ & & & 100 & & & & \\
\hline 21 & THORIUM 234 & No & $0.812 \mathrm{pCi} / \mathrm{g}$ & 4.00E-12 & 3.50E-09 & & & 100 & & & & \\
\hline 22 & TRITIUM (MYDHOGEN 3) & $1,600 \mathrm{pCi} / \mathrm{a}$ & & 5.40E-14 & of & & & 3,000 & & & & \\
\hline 23 & URANIUM 233 & $3.9 \mathrm{pCi} / \mathrm{e}$ & $2.3 \mathrm{pCi} / \mathrm{g}$ & $1.60 E-11$ & $4.20 \mathrm{E}-11$ & & & 50 & & & & \\
\hline 24 & URANIUM 234 & & $3.9 \mathrm{pCi} / \mathrm{g}$ & $1.60 E-11$ & $3.00 \mathrm{E}-11$ & & & 50 & & & & \\
\hline 25 & URANIUM 235 & $1.23 \mathrm{pCi} / \mathrm{g}$ & $0.1 \mathrm{pCl} / \mathrm{g}$ & $1.60 E-11$ & 2.40E-07 & & & 50 & & & & \\
\hline 26 & URANIUM 238 & $4.7 \mathrm{pCl} / \mathrm{g}$ & $3.2 \mathrm{pCl} / \mathrm{g}$ & $1.60 E-11$ & $2.10 E-11$ & & & 50 & & & & \\
\hline 27 & ZINC 65 & ND & $0.24 \mathrm{pCl} / \mathrm{g}$ & $8.50 E-12$ & 2.00E-06 & & & 2,500 & & & & \\
\hline 28 & ZIRCONIUM 95 & $0.66 \mathrm{pCi} / \mathrm{g}$ & & 9.90E-13 & $2.50 \mathrm{E}-06$ & & & 200 & & & & \\
\hline & Chorficals & & & & & & & & & & & \\
\hline 29 & ACENAPHTHENE & $210 \mu \mathrm{g} / \mathrm{kg}$ & & & & 0.06 & & 300 & 4.000 & & 1 & \\
\hline 30 & ALUMINUM & $26,700,000 \mu \mathrm{g} / \mathrm{kg}$ & $9,350,000 \mu \mathrm{g} / \mathrm{kg}$ & & & 0.004 & & 10 & 5.000 & & 7 & \\
\hline 31 & AMMONIA & $12.800 \mu \mathrm{g} / \mathrm{kg}$ & $12,000 \mu \mathrm{g} / \mathrm{kg}$ & & & 0.029 & & 0 & 1,800 & & & \\
\hline 32 & ANTHRACENE & $430 \mu \mathrm{g} / \mathrm{kg}$ & & & & 0.3 & & 3,000 & 4,000 & & 1 & \\
\hline 33 & AROCLOR 1248 (PCB) & $9,900 \mu \mathrm{g} / \mathrm{kg}$ & & & & & 7.7 & 10,000 & & 278 & & 0.014 \\
\hline 34 & ARSENIC & $47,000 \mu \mathrm{g} / \mathrm{kg}$ & $7,500 \mu \mathrm{g} / \mathrm{kg}$ & & & 0.0003 & 1.75 & 100 & 1.100 & & & 190 \\
\hline
\end{tabular}


Table B.2. (contd)

\begin{tabular}{|c|c|c|c|c|c|c|c|c|c|c|c|c|}
\hline & & & & Ingestion & External & & Cancer & Fish & & & Notes on & Water Quality \\
\hline & & Maximum Co & ncentration in & Slope Factor & Slope Factor & AfD & Potency Factor & Bioaccumulation & $1 C 50$ & TLM & Fish & Criteria \\
\hline & Name of Analyte & Soll & Sediment & (Risk/pCi) & (Risk/pci) & (mg/kg/day) & (11)/(mg/kg/day) & $(\mathrm{L} / \mathrm{kg})$ & (wg/h) & $\omega g / L)$ & Toxicity & $(\mu \mathrm{g} / \mathrm{L})$ \\
\hline & & & & & & & & & & & & \\
\hline 35 & BaRIUM & $672,000 \mu \mathrm{g} / \mathrm{kg}$ & $120,000 \mu \mathrm{g} / \mathrm{kg}$ & & & 0.07 & & 200 & 400,000 & & & \\
\hline 36 & BENZENE & $4,500 \mu \mathrm{g} / \mathrm{kg}$ & & & & & 0.029 & 10 & & 20 & & \\
\hline 37 & BENZOIG,H,UPERYLENE & $410 \mu \mathrm{g} / \mathrm{kg}$ & & & & & & & 4,000 & & 1 & \\
\hline 38 & BENZO\{a]ANTHRACENE & $940 \mu \mathrm{g} / \mathrm{kg}$ & & & & & 0.84 & 12,000 & 4,000 & & 1 & \\
\hline 39 & BENZOIa]PYRENE & $810 \mu \mathrm{g} / \mathrm{kg}$ & & & & & 5.79 & 20,000 & 4,000 & & 1 & \\
\hline 40 & BENZO(b)FLUORANTHENE & $890 \mu \mathrm{g} / \mathrm{kg}$ & & & & & 0.81 & 20.000 & 4,000 & & 1 & \\
\hline 41 & BENZOIKIFLUORANTHENE & $760 \mu \mathrm{g} / \mathrm{kg}$ & & & & & 0.38 & 20,000 & 4,000 & & 1 & \\
\hline 42 & BENZOIC ACID & $1.700 \mu \mathrm{g} / \mathrm{kg}$ & & . & & 4 & & 6 & 180,000 & & & \\
\hline 43 & BERYLLIUM & $8,000 \mu \mathrm{g} / \mathrm{kg}$ & $1.100 \mu \mathrm{g} / \mathrm{kg}$ & & & 0.005 & 4.3 & 19 & 200 & & & \\
\hline 44 & BIS(2-ETHYLHEXYL) PHTHALATE & $68,000 \mu \mathrm{g} / \mathrm{kg}$ &. & & & 0.02 & 0.014 & 70 & & 32,000 & & \\
\hline 45 & CADMIUM & $1.800 \mu \mathrm{g} / \mathrm{kg}$ & $2,700 \mu \mathrm{g} / \mathrm{kg}$ & & & 0.0005 & 6.3 & 200 & & 30,000 & & 1.1 \\
\hline 46 & CALCIUM & $40,800,000 \mu \mathrm{g} / \mathrm{kg}$ & $4,460,000 \mu \mathrm{g} / \mathrm{kg}$ & & & & & & & & & \\
\hline 47 & CHLORDANE & $4,500 \mu \mathrm{g} / \mathrm{kg}$ & & & & 0.00006 & 1.3 & 322 & 8 & & & 0.0043 \\
\hline 48 & CHLORIDE & $1.100 \mu \mathrm{g} / \mathrm{kg}$ & & & & 0.011 & & 50 & & & & \\
\hline 49 & CHLORINE (a) & & & & & & & & & & & \\
\hline 50 & CHROMIUM & $259,000 \mu g^{\prime} \mathrm{kg}$ & $12,200 \mu \mathrm{g} / \mathrm{kg}$ & & & 1 & 41 & 200 & 1,000 & & & 11 \\
\hline 51 & CHAYSENE & $920 \mu \mathrm{g} / \mathrm{kg}$ & & & & & 0.0255 & 20.000 & 4,000 & & 1 & \\
\hline 52 & COBALT & $34,100 \mu \mathrm{g} / \mathrm{kg}$ & $11,500 \mu \mathrm{g} / \mathrm{kg}$ & & & 0.0081 & & 50 & & $10,000,000$ & & \\
\hline 53 & COPPER & $40,000,000 \mu \mathrm{g} / \mathrm{kg}$ & $40,000 \mu \mathrm{g} / \mathrm{kg}$ & & & 0.0003 & & 50 & 500 & & & 12 \\
\hline 54 & CVANIDE & $1,060 \mu \mathrm{g} / \mathrm{kg}$ & & & & 0.02 & & 0 & & & & 5.2 \\
\hline 55 & DIBENZOFURAN & $130 \mu \mathrm{g} / \mathrm{kg}$ & & & & & & & & & & \\
\hline 56 & DIESEL FUEL & $2,800,000 \mu \mathrm{g} / \mathrm{kg}$ & & & & 0.36 & & 300 & 1.000 & & & \\
\hline 57 & ENDRIN ALDEHYDE & $3.3 \mu \mathrm{g} / \mathrm{kg}$ & & & & 0.0003 & & 1,480 & 0 & & 2 & \\
\hline 58 & ETHYL BENZENE & $32,000 \mu \mathrm{g} / \mathrm{kg}$ & & & & 0.1 & & 100 & & 30 & & \\
\hline 59 & FLUORANTHENE & $1,800 \mu \mathrm{g} / \mathrm{kg}$ & & & & 0.04 & & 3,000 & 4,000 & & 1 & \\
\hline 60 & FLUORENE & $190 \mu \mathrm{g} / \mathrm{kg}$ & & & & 0.04 & & 713 & 4,000 & & 1 & \\
\hline 61 & FLUORIDE & $4,700 \mu \mathrm{g} / \mathrm{kg}$ & & & & 0.04 & & 10 & & 2,300 & 3 & \\
\hline 62 & FLUORINE (a) & & & & & & & & & & & \\
\hline 63 & INDENO(1,2,3-CD)PYRENE & $520 \mu \mathrm{g} / \mathrm{kg}$ & & & & & 1.34 & 40.000 & 4,000 & & 1 & \\
\hline 64 & IRON & $33,500,000 \mu \mathrm{g} / \mathrm{kg}$ & $71,000,000 \mu \mathrm{g} / \mathrm{kg}$ & & & 1.3 & & 2,000 & & & & \\
\hline 65 & KEROSENE & $3,085,000 \mu \mathrm{g} / \mathrm{kg}$ & & & & 0.7 & & 300 & & 200 & & \\
\hline 66 & LEAD & $540,000 \mu \mathrm{g} / \mathrm{kg}$ & $73,000 \mu \mathrm{g} / \mathrm{kg}$ & & & 0.0014 & & 100 & & 530 & & 3.2 \\
\hline 67 & LITHIUM (a) & & & & & & & & & & & \\
\hline 68 & MAGNESIUM & $11,600,000 \mu \mathrm{g} / \mathrm{kg}$ & $7,600,000 \mu \mathrm{g} / \mathrm{kg}$ & & & & & & & & & \\
\hline 69 & MANGANESE & $839,000 \mu \mathrm{g} / \mathrm{kg}$ & $578,000 \mu \mathrm{g} / \mathrm{kg}$ & & & & & & & 500.000 & & \\
\hline 70 & MERCURY & $4,300 \mu \mathrm{g} / \mathrm{kg}$ & & & & 0.0003 & & 1.000 & 10 & & & 0.012 \\
\hline
\end{tabular}


Table B.2. (contd)

\begin{tabular}{|c|c|c|c|c|c|c|c|c|c|c|c|c|}
\hline & & & & \multirow{3}{*}{$\begin{array}{l}\text { Ingestion } \\
\text { Slope Factor } \\
\text { (Risk/pci) } \\
\end{array}$} & \multirow{3}{*}{$\begin{array}{l}\text { External } \\
\text { Stope Factor } \\
\text { (Alisk/pCi) }\end{array}$} & \multirow{3}{*}{$\begin{array}{c}\text { RfD } \\
\text { (mg/kg/day) } \\
\end{array}$} & \multirow{3}{*}{$\begin{array}{c}\text { Cancer } \\
\text { Potoncy Factor } \\
\text { (11)/(mg/kg/day) } \\
\end{array}$} & \multirow{3}{*}{\begin{tabular}{|c|} 
Fish \\
Bloaccumulation \\
$(\mathrm{L} / \mathrm{kg})$ \\
\end{tabular}} & \multirow{3}{*}{$\begin{array}{l}\text { LC50 } \\
\text { (ug/L) } \\
\end{array}$} & \multirow{3}{*}{$\frac{T L M}{\left(\mu g^{\prime} / L\right)}$} & \multirow{3}{*}{\begin{tabular}{|c|} 
Notes on \\
Fish \\
Toxicity \\
\end{tabular}} & \multirow{3}{*}{$\begin{array}{c}\text { Water Quality } \\
\text { Criteria } \\
(\mu \mathrm{g} / \mathrm{L}) \\
\end{array}$} \\
\hline & & \multicolumn{2}{|c|}{ Maximum Concontration in } & & & & & & & & & \\
\hline & Name of Analyte & Soll & Sediment & & & & & & & & & \\
\hline & & & & & & & & & & & & \\
\hline 71 & METHYL-2-PENTANONE, 4- & $22,000 \mu \mathrm{g} / \mathrm{kg}$ & & & & & & & & & & \\
\hline 72 & METHYLENE CHLORIDE & $120 \mu \mathrm{g} / \mathrm{kg}$ & & . & & 0.06 & 0.0075 & 3 & 550,000 & & 4 & \\
\hline 73 & METHYLNAPHTHALENE, 2 - & $42 \mu \mathrm{g} / \mathrm{kg}$ & & & & & & & 4,000 & & 1 & \\
\hline 74 & NICKEL & $221,000 \mu \mathrm{g} / \mathrm{kg}$ & $19,700 \mu \mathrm{g} / \mathrm{kg}$ & & & 0.02 & & 100 & & 380 & & 160 \\
\hline 75 & NITRATE & $30,400 \mu \mathrm{gg} / \mathrm{kg}$ & & & & 1.6 & & 150,000 & 20,000 & & 5 & \\
\hline 76 & PHENANTHRENE & $1,500 \mu \mathrm{g} / \mathrm{kg}$ & & & & 0.04 & & 1.000 & 4,000 & & 1 & \\
\hline 77 & POTASSIUM & $4,980,000 \mu \mathrm{g} / \mathrm{kg}$ & $1,900,000 \mu \mathrm{g} / \mathrm{kg}$ & & & & & & 80,000 & & & \\
\hline 78 & PYRENE & $1.200 \mu \mathrm{g} / \mathrm{kg}$ & & & & 0.03 & & 2,800 & 4,000 & & 1 & \\
\hline 79 & SELENIUM & $4,200 \mu \mathrm{g} / \mathrm{kg}$ & & & & 0.005 & & 170 & 2,500 & & & 5 \\
\hline 80 & SILVER & $1.900 \mu \mathrm{g} / \mathrm{kg}$ & $2,500 \mu \mathrm{g} / \mathrm{kg}$ & & & & & & 4 & & & \\
\hline 81 & SILVER CHLORIDE & $17,300,000 \mu \mathrm{g} / \mathrm{kg}$ & & & & 0.005 & & 2 & & & & \\
\hline 82 & SODIUM & $1.770,000 \mu \mathrm{g} / \mathrm{kg}$ & $920,000 \mu \mathrm{g} / \mathrm{kg}$ & & & & & & & $4,720,000$ & & \\
\hline 83 & STRONTIUM & $67,000 \mu \mathrm{g} / \mathrm{kg}$ & & & & 0.6 & & 50 & & 200,000 & 6 & \\
\hline 84 & STRONTIUM CHLORIOE & $1 \mu \mathrm{g} / \mathrm{kg}$ & & & & 0.6 & & 50 & & 200,000 & & \\
\hline 85 & SULFATE (SULFUR) & $131,000 \mu \mathrm{g} / \mathrm{kg}$ & & & & 71 & & 750 & & 80,000 & & \\
\hline 86 & TITANIUM (a) & & & & & & & & & & & \\
\hline 87 & TOLUENE & $350.000 \mu \mathrm{g} / \mathrm{kg}$ & & & & 0.2 & & 20 & 60,000 & & & \\
\hline 88 & TOTAL PETROLEUM HYDROCARBON & $1.26 \mathrm{E}+08$ & & & & & & & & & & \\
\hline 89 & VANADIUM & $389,000 \mu \mathrm{g} / \mathrm{kg}$ & $82,200 \mu \mathrm{g} / \mathrm{kg}$ & & & & & & & 55,000 & & \\
\hline 90 & XYLENE & $1,800,000 \mu \mathrm{g} / \mathrm{kg}$ & & & & 0.2 & & 150 & & 4,000 & & \\
\hline 91 & ZINC & $309,000 \mu \mathrm{g} / \mathrm{kg}$ & $397,000 \mu \mathrm{g} / \mathrm{kg}$ & & & 0.3 & & 2.500 & 430 & & & 110 \\
\hline 92 & ZIRCONIUM (a) & & & & & & & & & & & \\
\hline & & & & & & & & & & & & \\
\hline (a) & Concentrations of these chemcials fall & within & & & & & & & & & & \\
\hline & their respectively occurring background & d levels. & & & & & & & & & & \\
\hline & & & & & & & & & & & & \\
\hline & Notes on Fish Toxiclty & & & & & & & & & & & \\
\hline 1 & assume naphthalene & & & & & & & & & & & \\
\hline 2 & assume endrine & & & & & & & & & & & \\
\hline 3 & assume fluorine & & & & & & & & & & & \\
\hline 4 & assume chloromethane & & & & & & & & & & & \\
\hline 5 & assume ferric nitrate & & & & & & & . & & & & \\
\hline 6 & assume strontium chloride & & & & & & & & & & & \\
\hline & assume aluminum hydroxide & & & & & & & . & & & & \\
\hline
\end{tabular}


Table B.3. Parameters Used to Screen Groundwater Away from the Columbia River

\begin{tabular}{|c|c|c|c|c|c|c|c|c|c|c|c|}
\hline & & & & Ingestion & External & & & $\therefore$ & & & \\
\hline & & & & Slope & Slope & & Cancer & Fish & & & Water Quality \\
\hline & Number & Maximum & & Factor & Factor & BID & Potancy Factor & Bioaccumulation & LC50 & TLM & Criteria \\
\hline Name of Analyte & of Plumes & Concentration & Reference & (Risk/pCi) & (Risk/pCi) & (mg/kg/day) & $(\mathrm{mg} / \mathrm{kg} / \mathrm{day})$ & (L/kg) & (ug/L) & $(\mu \mathrm{g} / \mathrm{L})$ & $\psi(\mu / \mathrm{L})$ \\
\hline \multicolumn{12}{|l|}{100 Aroas } \\
\hline Chromium $(+6)$ & 3 & $1,570 \mathrm{ppb}$ & DOE 1994b & & & 1 & 41 & 200 & 1000 & & 11 \\
\hline Nitrate & 10 & $130,000 \mathrm{ppb}$ & DOE 1994b & & & 2 & & 150,000 & 20,000 & & 11 \\
\hline Strontium-90 & 8 & $1,800 \mathrm{pCi} / \mathrm{L}$ & DOE 1994b & 0 & 0 & & & 50 & & & \\
\hline \multirow{3}{*}{ Tritium (Hyrdrogen-3) } & 4 & $80,000 \mathrm{pCi}$ & DOE 1994b & 0 & 0 & & & 1 & & & \\
\hline & \multirow{2}{*}{\multicolumn{11}{|c|}{200 West Area }} \\
\hline & & & & & & & & & & & \\
\hline Arsenic & 4 & $24 \mathrm{ppb}$ & Ford 1993 & & & 0 & 2 & 100 & 1,100 & & 190 \\
\hline Carbon Tetrachloride & 1 & $6.559 \mathrm{ppb}$ & Ford 1993 & & & 0 & 0 & 150 & 125,000 & & \\
\hline Chloroform & 2 & $1,595 \mathrm{ppb}$ & Ford 1993 & & & 0 & 0 & 100 & 100,000 & & \\
\hline Chromium & 5 & $323 \mathrm{ppb}$ & Ford 1993 & & & 1 & 41 & 200 & 1.000 & & 11 \\
\hline Fluoride & 3 & $10.067 \mathrm{ppb}$ & Ford 1993 & & & 0 & & 10 & & 2,300 & \\
\hline lodine-129 & 2 & $30 \mathrm{pCi} / \mathrm{L}$ & Ford 1993 & o & 0 & & 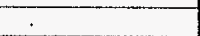 & 15 & & & \\
\hline Nitrate & 5 & $1,322,000 \mathrm{ppb}$ & Ford 1993 & & & 2 & & 150,000 & 20,000 & & \\
\hline Technetium-99 & 5 & $26,602 \mathrm{pCi} / \mathrm{L}$ & Ford 1993 & 0 & 0 & & & 15 & & & \\
\hline Trichloroethylene & 3 & $32 \mathrm{ppb}$ & Ford 1993 & & & & 0 & 11 & 55,000 & & \\
\hline Tritium (Hydrogen-3) & 3 & $6,193,000 \mathrm{pCi} / \mathrm{L}$ & Ford 1993 & 0 & 0 & & & 1 & & & \\
\hline Uranium & 4 & $1.616 \mathrm{pCi} / \mathrm{L}$ & DOE 1994b & 0 & 0 & & & 50 & & & \\
\hline & & & & & & & & & & & \\
\hline \multicolumn{12}{|l|}{200 East Area } \\
\hline Arșenic & 4 & $24 \mathrm{ppb}$ & Ford 1993 & & & 0 & 2 & 100 & 1,100 & & $\overline{190}$ \\
\hline Cesium-137 & 1 & $1,326 \mathrm{pCi} / \mathrm{L}$ & Ford 1993 & 0 & 0 & & & 2,000 & & & \\
\hline Chloroform & 1 & $7 \mathrm{ppb}$ & DOE 1994b & & & 0 & 0 & 100 & 100,000 & & \\
\hline Chromium & 4 & $288 \mathrm{ppb}$ & Ford 1993 & & & 1 & 41 & 200 & 1,000 & & 11 \\
\hline Cobalt -60 & 2 & $440 \mathrm{pCi} / \mathrm{L}$ & Ford 1993 & 0 & 0 & & & 330 & & & \\
\hline Cyanide & 2 & $893 \mathrm{ppb}$ & Ford 1993 & & & 0 & & 0 & & & 5 \\
\hline lodine-129 & 3 & $20 \mathrm{pCi} / \mathrm{L}$ & Ford 1993 & 0 & of & & & 15 & & & \\
\hline Nitrate & 7 & $397,000 \mathrm{ppb}$ & Ford 1993 & & & 2 & & 150,000 & 20,000 & & \\
\hline Plutonium-239/240 & 1 & $69 \mathrm{pCi} / \mathrm{L}$ & Ford 1993 & & & & & & & & \\
\hline Strontium-90 & 5 & $5,149 \mathrm{pCill}$ & Ford 1993 & 0 & 0 & & & 50 & & & \\
\hline Technatium-99 & 2 & $22,163 \mathrm{pCi} / \mathrm{L}$ & Ford 1993 & 0 & 0 & & & 15 & & & \\
\hline Tritium (Hydrogen-3) & 5 & $4,126,000 \mathrm{pCi} / \mathrm{L}$ & Ford 1993 & 0 & 0 & & & 1 & & & \\
\hline \multirow[t]{3}{*}{ Uranium } & 1 & $27 \mathrm{pCi} / \mathrm{L}$ & Ford 1993 & 0 & 0 & & & 50 & & & \\
\hline & & & & & & & & & & & \\
\hline & & & & & & & & & & & \\
\hline \multicolumn{12}{|c|}{600 Area (Solid Waste Landfill Sito) } \\
\hline Chloroform & 1 & $0.5 \mathrm{ppb}$ & DOE 1994b & & & 0 & 0 & 100 & 100,000 & & \\
\hline Dichloroethane, 1,1 - & 1 & $7 \mathrm{ppb}$ & DOE 1994b & & & 0 & & 7 & 220,000 & & \\
\hline Tetrachloroethene & 1 & $12 \mathrm{ppb}$ & DOE 1994b & & & 0 & 0 & 100 & 13,000 & & \\
\hline Trichloroethane, $1,1,1$ & 1 & $50 \mathrm{ppb}$ & DOE 1994b & & & 은 & 0 & 39 & 50,000 & & \\
\hline Trichloroethene & 1 & $7 \mathrm{ppb}$ & DOE 1994b & & & & 0 & 52 & 55,000 & & \\
\hline
\end{tabular}




\section{Appendix C}

Complete Numerical Results 


\section{Appendix C}

\section{Complete Numerical Results}

This appendix provides the numerical results of applying the screening equations in Section 4.0 to the detected analytes described in Sections 3.0 and 7.0. Table C.1 presents the numerical results of screening samples at the Columbia River and groundwater within 150 meters (500 feet) of the Columbia River. Table C.2 presents the numerical results of screening soil and sediment samples. Table C. 3 presents the numerical results of screening samples from groundwater farther than 150 meters ( 500 feet) from the Columbia River. Application of the equations and assumptions defined in Section 4.0 results in a series of complementary, but not necessarily intercomparible, screening values for each contaminant. The varying numbers of assumptions and associated varying degrees of conservatism require that each of the screenings be evaluated separately. The results of the combined screenings, however, then define the overall list of contaminants of concern.

Each table includes a "notes" column. The notes consist of abbreviated designations. The following are the full descriptions of each designation as well as explanations of the column headings.

\footnotetext{
Bkg = background denotes that the highest concentration found was at background level so eliminated from consideration.

EPA-10 = eliminated based on the guidance in EPA Region 10 Supplemental Risk Assessment Guidance for Superfund (EPA 1991).

I = parameters derived from the Integrated Risk Information System (IRIS) database (EPA 1994b).

Inadequate? = insufficient information available to classify as toxic or having carcinogenic properties.

LC50/100 = lowest concentration reported to be lethal to aquatic life 100 days after exposure, as reported in EPA 1985.

$\mathrm{LD}=$ near limit of detection.

$\mathrm{M}$ = parameters derived from the Multimedia Environmental Pollutant Assessment System (MEPAS) database (Droppo et al. 1991).

ND $=$ not detected.

Non-Haz.? = analyte not designated in database as containing hazardous properties.

Suspect $=$ noted in the source database as being unreliable (see Section 4.4).

SW = surface water (Columbia River water).

SW-LD = reported sample in surface water very near the limit of detection and, therefore, unreliable.

$\mathrm{T} 1 / 2=$ half-life of analyte indicates that any concentration present at sampling should now be decayed to insignificance.

TLM = lowest concentration below which no effects on aquatic life are observed, as reported in EPA 1985.

Unclass? = not classified in MEPAS or IRIS as hazardous.

WQC = water quality criteria.
} 


\begin{tabular}{|c|c|c|c|c|c|c|c|c|c|c|c|c|}
\hline $90 \cdot 309 \cdot \varepsilon$ & & & & & & & & $\angle 0-316^{\circ} 6$ & & & NIZVYOAH & $1 \varepsilon$ \\
\hline \multirow[t]{3}{*}{$60-360.6$} & & & & & & $60 \cdot \exists+8 \cdot 2$ & & & & 6×a-MS 'W & zalyonาs & $O E$ \\
\hline & & & & & & & & $\angle 0-90 Z^{\cdot} 8$ & & & tgL WnIdOrna & 62 \\
\hline & & & & & & $D O-\exists \angle 8^{\circ} L$ & & $90-368^{\prime} I$ & & 1 & 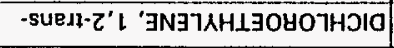 & 82 \\
\hline \multirow[t]{12}{*}{$90-300.6$} & & & & & & & & $80-\exists 9 L^{\circ} 6$ & & 1) & 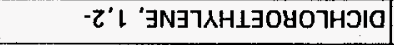 & $\angle Z$ \\
\hline & & & & $80-390 * t$ & & $90-309^{\circ} t$ & & & & $w$ & JOIN $\forall \wedge 3$ & 92 \\
\hline & & $10-\exists \varepsilon 01$ & $00+30 t+t$ & $20-30 \varepsilon^{\prime} t$ & $00+\exists E 8 \cdot \mathrm{I}$ & $10-301^{\circ} \mathrm{t}$ & $10+39 L \cdot 1$ & & & O7-MS 'W & y3dd00 & 92 \\
\hline & & & & & & & & $70 \cdot 302 \cdot 1$ & $90-\exists \angle t 6$ & & $0917 \forall 800$ & $\nabla z$ \\
\hline & & & & & & $\not 0-\exists 9 \varepsilon z$ & & & & $w$ & 178800 & $\varepsilon z$ \\
\hline & & $10 \cdot 396 \cdot 1$ & & $10 \cdot \exists \angle L ' L$ & & E0-ヨเ9. & & $20 \cdot 309 \cdot 9$ & & O7-MS I & WniwoyHว & 22 \\
\hline & & 50-302*6 & & & & $80-328 \% 1$ & & $\angle 0-360 \cdot 1$ & & 1 & WะOยОษОาHว & 12 \\
\hline & & & & & & & & & & 6×8-MS 'W & $\exists$ 밍ㄱㄱㄱㅣ & $0 z$ \\
\hline & & & & & & & & $\angle 0-\exists E O^{\prime} I$ & $90 \cdot 3 \angle 9^{\circ} Z$ & & $\angle E !$ WnIS 3 & 61 \\
\hline & & & & & & & & & $90-\exists \triangleright \varepsilon^{\prime} 9$ & & $t \varepsilon \perp$ wnISJJ & 81 \\
\hline & & & & & & & & $90-3796$ & & & $\rightarrow 1$ NOB甘 $\forall 3$ & $\angle 1$ \\
\hline & & & & & & & & & & $0 L-\forall d g^{\prime} W^{\prime} 6 y g$ & พกIวาทว & 91 \\
\hline \multirow[t]{3}{*}{$90-3 \varepsilon 0 \div$} & & & & $20-328 \cdot 2$ & & $20 \cdot 321 \cdot 9$ & & +0.3191 & & 1 & wniwa & 91 \\
\hline & & & & & & & & & & $1^{\prime} 6 \times 8$ & NOHOQ & $\forall i$ \\
\hline & & & & & & & & & & $w^{\prime} 6 \times 9$ & HLnWSIg & $\varepsilon \imath$ \\
\hline \multirow[t]{7}{*}{$90-399 \cdot 1$} & & & & & & $b 0-\exists Z 6 . L$ & & $\angle O \cdot \exists Z \tau \cdot \tau$ & & I & 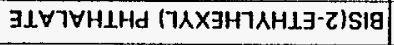 & 21 \\
\hline & & & & & & & & & & 6xg & $\angle$ Wn177 4838 & 11 \\
\hline & & $\varepsilon 0^{-} \exists 00^{\circ} \varepsilon$ & & & & $00-31+1$ & & $90-\exists Z 0^{\circ} \varepsilon$ & & 1 & WกI77人ㅂg & 01 \\
\hline & & $\$ 0-708 \cdot 1$ & $20-\exists 12 \cdot 1$ & & & $80-38+\cdot 8$ & & & & Byg-MS i & wniy & 6 \\
\hline & - & E0-تGg't & $10-360^{\circ} \varepsilon$ & $90 \cdot 396.8$ & $20-36 L$ & $20-\exists 9 b^{\prime} Z$ & $00+\exists 26^{\circ} t$ & $90-362 \cdot 1$ & $80-\exists 897$ & 1 & כIṄSY & 8 \\
\hline & & & & & & & & $90 \cdot 30+2$ & & & GZL ANOWIINV & $L$ \\
\hline & & & & & & $10 \cdot \exists t 2 \cdot 1$ & & & & & ANOWIINY & 9 \\
\hline \multirow[t]{4}{*}{$\$ 0-390.6$} & & & & & & $\$ 0-306 . \mathrm{L}$ & & & & $\mathbf{w}$ & WNINOWWY & 9 \\
\hline & & $\varepsilon 0^{-}-368^{\prime} \varepsilon$ & & & & $\$ 0 \cdot 390 \div$ & & & & & VINOWWY & $t$ \\
\hline & & & & & & & & $01-\exists Z \nabla^{-1}$ & & & LbZ Wกเวเ8ヨw & $\varepsilon$ \\
\hline & & & & & & & & & & $0 l-\forall d 3^{\prime} W$ & WกNIWก77 & 2 \\
\hline $60-309 \cdot 2$ & $60 \cdot \exists 9 \angle 2$ & & & & & G0-ヨIE'l & $80 \cdot 308^{\circ}$ & & & 07-MS 'W & $\exists N O \perp \exists O V$ & 1 \\
\hline 101eM & LaleM & sezem & POIEM & 1018M & JO2EM & IEIBM & JE1EM & $1018 \mathrm{M}$ & IO1EM & selon & 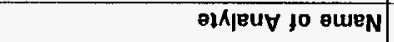 & \\
\hline -punosg & әכejuns & -punoג9 & exepuns & -punods & expuns & -punosg & evepuns & -punors & evejuns & & & \\
\hline \multicolumn{2}{|c|}{ бu!Yuey uвอ10S W71 } & \multicolumn{2}{|c|}{ 6ulyuey uoasos 00L/0957 } & \multicolumn{2}{|c|}{ Gu!yuey UәอIOS JOM } & \multicolumn{2}{|c|}{ Gulquey xepul prezeH } & \multicolumn{2}{|c|}{ 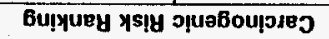 } & & & \\
\hline
\end{tabular}

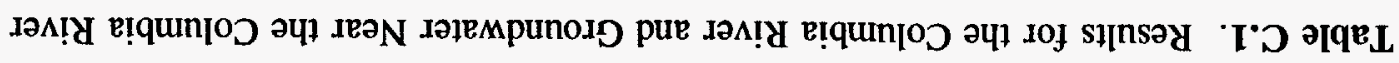


Table C.1. (contd)

\begin{tabular}{|c|c|c|c|c|c|c|c|c|c|c|c|c|}
\hline & & & \multicolumn{2}{|c|}{ Carcinogenic Risk Ranking } & \multicolumn{2}{|c|}{ Hazard Index Ranking } & \multicolumn{2}{|c|}{ WOC Screen Ranking } & \multicolumn{2}{|c|}{ LC50/100 Screen Ranking } & \multicolumn{2}{|c|}{ TLM Screen Ranking } \\
\hline & & & Surface & Ground- & Surface & Ground- & Surface & Ground- & Surface & Ground- & Surface & Ground- \\
\hline & Name of Analyte & Notes & Water & water & Water & water & Water & water & Water & water & Water & water \\
\hline 32 & IODINE 129 & & $1.44 \mathrm{E}-07$ & & & & & & & & & \\
\hline 33 & IRON & M,EPA-10 & & & & & & & & & & \\
\hline 34 & LEAD & $M$ & & & & 5.37E-02 & & $5.41 \mathrm{E}-02$ & & & & $3.26 \mathrm{E}-04$ \\
\hline 35 & LITHIUM & $B k g, M$ & & & & & & & & & & \\
\hline 36 & MAGNESIUM & M,EPA-10 & & & & & & & & & & \\
\hline 37 & MANGANESE & $M$ & & & 5.24E-01 & 9.19E-03 & & & & & $4.56 \mathrm{E}-03$ & 8.00E-07 \\
\hline 38 & MERCURY & $M$ & & & & 1.17E-01 & & 7.42E-01 & & $8.90 \mathrm{E}-02$ & & \\
\hline 39 & METHYL ETHYL KETONE & 1 & & & & $4.29 \mathrm{E}-06$ & & & & $3.21 \mathrm{E}-07$ & & \\
\hline 40 & METHYLENE CHLORIDE & 1 & & $1.20 \mathrm{E}-06$ & & 2.67E-03 & & & & $5.63 \mathrm{E}-04$ & & \\
\hline 41 & NICKEL & M, SW-LD & & & 6.73E-01 & $1.04 \mathrm{E}-02$ & $1.94 \mathrm{E}-01$ & 2.99E-03 & & & $8.16 E+00$ & $1.26 \mathrm{E}-03$ \\
\hline 42 & NITAATE & $M$ & & & $1.76 \mathrm{E}+02$ & $3.30 E+01$ & & & $2.40 E+00$ & 4.50E-01 & & \\
\hline 43 & NITRITE & & & $\ldots$ & & $1.04 E+03$ & & & & $3.00 E-01$ & & \\
\hline 44 & PHOSPHATE & $M$ & & & & $1.93 E+00$ & & & & & & 5.49E-05 \\
\hline 45 & PLUTONIUM 238 & & & $5.74 \mathrm{E}-11$ & & & & & & & & \\
\hline 46 & PLUTONIUM 239 & & & 1.80E-10 & & & & & & & & \\
\hline 47 & POTASSIUM & Bkg,M,EPA-1 & & & & & & & & & & \\
\hline 48 & RADIUM 226 & & & $6.51 E-10$ & & & & & & & & \\
\hline 49 & RUTHENIUM $106+D$ & & & $2.31 \mathrm{E}-06$ & & & & & & & & \\
\hline 50 & SELENIUM & $M$ & & 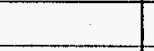 & & $2.44 \mathrm{E}-03$ & & $3.44 \mathrm{E}-03$ & & & - & $6.88 \mathrm{E}-06$ \\
\hline $51:$ & SILICON & Bikg, M & & & & & & & & & & \\
\hline 52 & SILVER & Bkg.I & & & & & & & & & & \\
\hline 53 & SODIUM & M,EPA-10 & & & & & & & & & & \\
\hline 54 & STRONTIUM & $M$ & & & & $1.23 \mathrm{E}-04$ & & & & & & $1.55 \mathrm{E}-06$ \\
\hline 55 & STRONTIUM 90 & & $5.63 \mathrm{E}-06$ & $1.61 \mathrm{E}-05$ & & & & & & & & \\
\hline 56 & SULFATE & M, SW-Bkg & & & & $2.52 \mathrm{E}-02$ & & & & & & 7.50E-03 \\
\hline 57 & SULFIDE & & & & & & & & & & & $3.75 \mathrm{E}-05$ \\
\hline 58 & TECHNETIUM 99 & & & $7.79 E-09$ & & & & & & & & \\
\hline 59 & TETRACHLOROETHYLENE & $M$ & & 8.64E-07 & & & & & & 2.17E-04 & & \\
\hline 60 & THALLIUM & & & & & 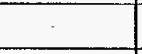 & & & & $1.00 E-02$ & & \\
\hline 61 & THORIUM 228 & & & 1.67E-06 & & & & & & & & \\
\hline 62 & THORIUM 232 & & & 6.04E.09 & & & & & & & & \\
\hline
\end{tabular}


Table C.1. (contd)

\begin{tabular}{|c|c|c|c|c|c|c|c|c|c|c|c|c|}
\hline & & & \multicolumn{2}{|c|}{ Carcinogenic Aisk Ranking } & \multicolumn{2}{|c|}{ Hazard Index Ranking } & \multicolumn{2}{|c|}{ WOC Screen Ranking } & \multicolumn{2}{|c|}{ LC50/100 Screen Ranking } & \multicolumn{2}{|c|}{ TLM Screen Ranking } \\
\hline & & & Surface & Ground- & Surface & Ground- & Surface & Ground- & Surface & Ground- & Surface & Ground- \\
\hline & Name of Analyte & Notes & Water & water & Water & water & Water & water & Water & water & Water & water \\
\hline 63 & TITANIUM & Bkg,M & & & & & & & & & & \\
\hline 64 & TOLUENE & \multicolumn{2}{|c|}{ SW sample suspect } & & 5.61E-03 & $3.46 \mathrm{E}-06$ & & & $7.83 \mathrm{E}-03$ & 4.83E-06 & & \\
\hline 65 & TRICHLOROETHYLENE & $M$ & & $2.28 \mathrm{E}-08$ & & & & & & 4.38E-05 & & \\
\hline 66 & TRITIUM (HYDROGEN 3) & & 2.86E-07 & $1.23 \mathrm{E}-07$ & & & & & & & & \\
\hline 67 & URANIUM 233 & & & $3.36 \mathrm{E}-10$ & & & & . & & & & \\
\hline 68 & URANIUM 234 & & $1.81 E-06$ & $1.21 \mathrm{E}-08$ & & & & & & & & \\
\hline 69 & URANIUM 235 & & $2.41 E-07$ & 4.10E-07 & & & & & & & & \\
\hline 70 & URANIUM 238 & & $1.89 \mathrm{E}-06$ & $9.26 \mathrm{E}-09$ & & & & & & & & \\
\hline 71 & VANADIUM & Bkg, M & & & & & & & & & & 7.27E-07 \\
\hline 72 & XYLENE & \multicolumn{2}{|c|}{ SW sample suspect } & & $1.26 \mathrm{E}-03$ & & & & & & $1.00 \mathrm{E}-01$ & \\
\hline 73 & ZINC & M, SW-LD & & & 3.60E-01 & $2: 88 E-01$ & 1.00E-01 & $8.00 \mathrm{E}-02$ & $2.56 \mathrm{E}+00$ & $2.05 E+00$ & & \\
\hline
\end{tabular}




\begin{tabular}{|c|c|c|c|c|c|c|c|c|c|c|c|c|}
\hline & & $\varepsilon 0-\exists \angle 9 \cdot 9$ & $\varepsilon 0-\exists 11 \cdot L$ & & & $70-318.1$ & to- $\exists \varepsilon 6.1$ & & & $w$ & FINOWWV & $1 \varepsilon$ \\
\hline & & & & & & & . & & & $0 L-\forall d 3^{\prime} w^{\prime} 6 \times 8$ & WกNIWกาช & $O \varepsilon$ \\
\hline & & & S0-39Z's & & & & $90-39 z^{\circ}$ & & . & $w$ & FNJHIHAVN $3 O \forall$ & 62 \\
\hline & & & & & & & & & & & 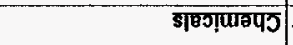 & \\
\hline & & & & & & & & & $90-30 t^{\prime} 1$ & & 96 WnINOJUIZ & 82 \\
\hline & & & & & & & & $\angle 0-398^{\circ} t$ & & Foadsns & 99 JNIZ & $\angle 2$ \\
\hline & & & & & & & & $60-36 l^{\circ} \varepsilon$ & $60-389 t$ & & $8 \varepsilon z$ WกIN $\forall \forall n$ & 92 \\
\hline & & & & & & & & $80 \cdot \exists 1 t \cdot 2$ & $\angle 0 \cdot 396 \cdot 2$ & & SEz WกIN $\forall \forall n$ & 92 \\
\hline & & & & & & & & $60-\exists Z 6^{\circ} \varepsilon$ & & & 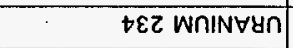 & $t z$ \\
\hline & & & & & & & & $60-\exists+\varepsilon \cdot 2$ & $60 \cdot \exists \angle 6 \cdot \varepsilon$ & & $\varepsilon \varepsilon z$ WกIN $\forall \forall n$ & $\varepsilon \tau$ \\
\hline & & & & & & & & & $\angle 0-309 \mathrm{z}$ & & 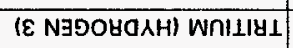 & $z z$ \\
\hline & & & & & & & & $60 \cdot 30 z^{\cdot} \varepsilon$ & & & 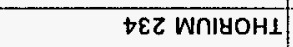 & 12 \\
\hline & & & & & & & & $60-36 \varepsilon^{\prime} t$ & $60-36 b^{\prime} \cdot t$ & & द६Z WกIYOH1 & $0 z$ \\
\hline & & & & & & & & $60 \cdot \exists 1 \varepsilon^{\circ} 9$ & $60-\exists 98 \cdot z$ & & $8 Z 2$ WNI4OH & 61 \\
\hline & & & & & & & & $11-3 z L 1$ & $\llcorner L-\exists 0 \varepsilon \cdot z$ & & 66 WกIIJNHOتI & 81 \\
\hline & & & & & & & & $\angle 0-391^{\circ} \mathrm{C}$ & $90-\exists 16^{\circ} I$ & & O6 WnILNOY $\perp S$ & $\angle 1$ \\
\hline & & & & & & & & $80^{-}-\exists 69^{\circ} \varepsilon$ & $80-\exists L \angle \cdot 9$ & & $9 z z$ wnIavy & 91 \\
\hline & & & & & & & & & & $6 \times 9$ & ob Wniss $\forall 1 O d$ & si \\
\hline & & & & & & & & & & & 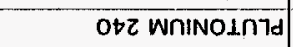 & 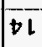 \\
\hline & & & & & & & & $60 \cdot 39 z \cdot t$ & $90-\exists 8 \varepsilon \cdot 1$ & & $6 \varepsilon 2$ wnINoInTd & $\varepsilon$ \\
\hline & & & & & & & & $11-\exists 19 \cdot 9$ & $\angle 0-\exists Z \varepsilon^{\prime} 9$ & & $8 \varepsilon 2$ WกINOLกาd & 21 \\
\hline & & & & & & & & & $\angle 0^{\circ} \exists E \varepsilon^{\circ} 9$ & & $897 \exists \times$ IIN & II \\
\hline 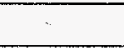 & & & & & & & & $80-396 \cdot \varepsilon$ & & & $\angle E Z$ WNINNLd & 01 \\
\hline & & & & & & & & $80-368 \mathrm{~L}$ & t0-399. $\varepsilon$ & & Ssi wnldoyn & 6 \\
\hline & & & & & & & & $\angle 0-368.6$ & $z 0-30 z \cdot 8$ & & tgL WnldOHก & 8 \\
\hline & & & & & & & & $90-389.8$ & $10-\exists Z 1 \cdot 2$ & & Zsl wnidoung & $L$ \\
\hline & & & & & & & & $90-\exists z z \cdot t$ & $10-399^{\circ} \mathrm{L}$ & & $09 \perp 7 \forall 900$ & 9 \\
\hline & & & & & & & & 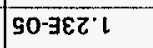 & $\varepsilon 0^{-396^{\circ} \mathrm{g}}$ & & $\angle E \downarrow$ WกIS & $s$ \\
\hline & & & & & & & & $90-\exists \varepsilon 9^{\prime} !$ & $\angle 0-\exists I L Z Z$ & & $\nabla \varepsilon \iota$ wnIS 30 & t \\
\hline & & & . & & & & & & LO-ヨ!ナ・ & & $\nabla 1$ NOgY $\forall 0$ & $\varepsilon$ \\
\hline & & & & & & & & & & $P 09=2 / L 1$ & TZI LNOWILNV & $z$ \\
\hline & & & & & & & & & $90-\exists 0 \varepsilon \cdot z$ & & เtz WกıวIy & I \\
\hline & & & & & & & & & & & 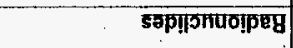 & \\
\hline juewipes & $110 \mathrm{~s}$ & SHatupas & 110s & Iиampes & 1109 & zueulpes & 108 & Ju8แipes & 1108 & selon & 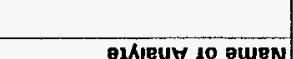 & \\
\hline \multicolumn{2}{|c|}{ 6uinuey uaess w71 } & \multicolumn{2}{|c|}{ 6ulyuey ureiss $00 \mathrm{~L} / 0957$} & \multicolumn{2}{|c|}{ Buyxuey uerios $00 \mathrm{M}$} & \multicolumn{2}{|c|}{ Bu!puzy xepul pdezeH } & \multicolumn{2}{|c|}{ 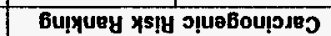 } & & & \\
\hline
\end{tabular}


Table C.2. (contd)

\begin{tabular}{|c|c|c|c|c|c|c|c|c|c|c|c|c|}
\hline & \multirow[b]{2}{*}{ Name of Analyte } & \multirow[b]{2}{*}{ Notes } & \multicolumn{2}{|c|}{ Carcinogenic Risk Ranking } & \multicolumn{2}{|c|}{ Hazard Index Ranking } & \multicolumn{2}{|c|}{ woc Screen Ranking } & \multicolumn{2}{|c|}{ LC50/100 Screen Ranking } & \multicolumn{2}{|c|}{ TLM Screen Ranking } \\
\hline & & & Soil & Sediment & Soil & Sodiment & Soil & Sediment & Soil & Sediment & Soil & Sediment \\
\hline & & & & & & & & & & & & \\
\hline 32 & ANTHRACENE & $M$ & & & $1.69 \mathrm{E}-04$ & & & & $1.08 \mathrm{E}-04$ & & & \\
\hline 33 & AROCLOR 1248 (PCB) & $M$ & $2.99 \mathrm{E}-02$ & & & & $7.07 E+00$ & & & & $3.56 \mathrm{E}-04$ & \\
\hline 34 & ARSENIC & 1 & 3.57E-04 & 6.70E-05 & $6.80 \mathrm{E}-01$ & $1.09 \mathrm{E}-01$ & 2.47E-03 & $3.95 \mathrm{E}-04$ & & $6.82 \mathrm{E}-03$ & & \\
\hline 35 & BARIUM & SD-Bkg, I & & & 7.93E-02 & & & & $1.68 \mathrm{E}-03$ & & & \\
\hline 36 & BENZENE & $M$ & $1.07 E-07$ & & & & & & & & $2.25 \mathrm{E}-03$ & \\
\hline 37 & BENZOIG,H,UPERYLENE & Non-Haz?,M & & & & & & & 1.03E-04 & & & \\
\hline 38 & BENZOlalANTHRACENE & $M$ & $3.71 E-04$ & & . & & & & $2.35 \mathrm{E}-04$ & & & \\
\hline 39 & BENZOIaIPYRENE & M, Suspect & $3.67 \mathrm{E}-03$ & & & & & & 2.03E-04 & & & \\
\hline 40 & BENZO|bJFLUORANTHENE & $M$ & 5.65E-04 & & & & & & $2.23 E-04$ & & & \\
\hline 41 & BENZOIKJFLUORANTHENE & $M$ & $2.26 \mathrm{E}-04$ & & & & & & $1.90 \mathrm{E}-04$ & & & \\
\hline 42 & BENZOIC ACID & $M$ & & & $2.82 \mathrm{E}-07$ & & & & $9.44 \mathrm{E}-06$ & & - & \\
\hline 43 & BERYLLIUM & 1 & $4.03 \mathrm{E}-05$ & $5.54 \mathrm{E}-06$ & $1.88 \mathrm{E}-03$ & $2.58 \mathrm{E}-04$ & & & 4.00E-02 & $5.50 \mathrm{E}-03$ & & \\
\hline 44 & BIS(2-ETHYLHEXYL) PHTHALATE & 1 & 3.02E-06 & & $1.08 \mathrm{E}-02$ & & & & & & & \\
\hline 45 & CADMIUM & 1 & $9.36 \mathrm{E}-05$ & $1.40 E-04$ & $2.97 \mathrm{E}-02$ & $4.46 E-02$ & 1.64E-02 & 2.45E-02 & & & $6.00 \mathrm{E}-07$ & 9.00E-07 \\
\hline 46 & CALCIUM & Bkg,M,EPA-10 & & & & & & & & & & \\
\hline 47 & CHLORDANE & 1 & $7.62 \mathrm{E}-05$ & & 9.77E-01 & & $1.05 E+01$ & & 5.49E-01 & & & \\
\hline 48 & CHLORIDE & Bkg,M & & & & & & & & & & \\
\hline 49 & CHLORINE (a) & Bkg, 1 & & & & & & & & & & \\
\hline 50 & CHROMIUM & 1 & $8.77 E-02$ & $4.13 \mathrm{E}-02$ & $2.14 \mathrm{E}-03$ & $1.01 \mathrm{E}-03$ & $2.35 \mathrm{E}-01$ & $1.11 \mathrm{E}-01$ & & $1.22 \mathrm{E}-01$ & & \\
\hline 51 & CHRYSENE & $M$ & 1.84E-05 & & & & & & & & & \\
\hline 52 & COBALT & $M$ & & & $1.00 \mathrm{E}-02$ & $3.39 \mathrm{E}-03$ & & & & & $3.41 \mathrm{E}-08$ & $1.15 \mathrm{E}-08$ \\
\hline 53 & COPPER & $M$ & & & $1.11 E+03$ & $3.18 \mathrm{E}-01$ & $1.17 E+02$ & 3.33E-02 & & $8.00 \mathrm{E}-02$ & & \\
\hline 54 & CYANIDE & $M$ & & & $2.29 \mathrm{E}-05$ & & $2.02 E-03$ & & & & & \\
\hline 55 & DIBENZOFURAN & Inadequate?,M & & & & & & & & & & \\
\hline 56 & DIESEL FUEL & $M$ & & & $9.47 \mathrm{E}-02$ & & & & $2.80 E+00$ & & & \\
\hline 57 & ENDRIN ALDEHYDE & $M$ & & & $6.42 \mathrm{E}-04$ & & & & $1.65 \mathrm{E}-02$ & & & \\
\hline 58 & ETHYL BENZENE & $M$ & . & & $1.39 \mathrm{E}-03$ & & & & & & 1.07E-02 & \\
\hline 59 & FLUORANTHENE & 1 & & & $5.30 \mathrm{E}-03$ & & & & 4.5OE-04 & & & \\
\hline 60 & FLUORENE & 1 & & & $1.35 \mathrm{E}-04$ & & & & 4.75E-05 & & & \\
\hline 61 & FLUORIDE & $M$ & & & $9.63 E-05$ & & & & & & $2.04 \mathrm{E}-05$ & \\
\hline 62 & FLUORINE (a) & $\mathrm{Bkg}, \mathrm{I}$ & & & & & & & & & & \\
\hline 63 & INDENO(1,2,3-CD)PYRENE & M, Suspect & $1.09 \mathrm{E}-03$ & & & & & & 1.30E-04 & & & \\
\hline 64 & IRON & M.EPA-10 & & & & & & & & & & \\
\hline
\end{tabular}


Table C.2. (contd)

\begin{tabular}{|c|c|c|c|c|c|c|c|c|c|c|c|c|}
\hline & \multirow[b]{2}{*}{ Name of Analyte } & \multirow[b]{2}{*}{ Notes } & \multicolumn{2}{|c|}{ Carcinogenic Risk Ranking } & \multicolumn{2}{|c|}{ Hazard Index Ranking } & \multicolumn{2}{|c|}{ WaC Screen Ranking } & \multicolumn{2}{|c|}{ LC50/100 Screen Ranking } & \multicolumn{2}{|c|}{ TLM Screen Ranking } \\
\hline & & & Soil & Sediment & Soll & Sediment & Soil & Sediment & Soil & Sediment & Soil & Sediment \\
\hline & & & & & & & & & & . & & \\
\hline 65 & KEROSENE & $M$ & & & 5.36E-O2 & & & & & & $1.54 \mathrm{E}-01$ & \\
\hline 66 & LEAD & $M$ & & & $1.67 E+00$ & 2.26E-01 & $1.69 E+00$ & $2.28 \mathrm{E}-01$ & & & $1.02 E-02$ & $1.38 E-03$ \\
\hline 67 & LITHIUM (a) & $B k g, M$ & . & & & & & & & & & \\
\hline 68 & MAGNESIUM & Bkg,M,EPA-10 & & & & & & & & & & \\
\hline 69 & MANGANESE & Bkg.M & & & & & & & & & & \\
\hline 70 & MERCURY & $M$ & & & 5.67E-01 & & $3.58 \mathrm{E}+00$ & & 4.30E-01 & & & \\
\hline 71 & METHYL-2-PENTANONE, 4- & Non-haz?,M & & & & & & & & & & \\
\hline 72 & METHYLENE CHLORIDE & 1 & $4.74 \mathrm{E}-10$ & & 1.05E-06 & & & & $2.18 \mathrm{E}-07$ & & & \\
\hline 73 & METHYLNAPHTHALENE, 2 - & Unclass ?,M & & & & & & & $1.05 \mathrm{E}-05$ & & & \\
\hline 74 & NICKEL & M & & & $4.80 \mathrm{E}-02$ & $4.28 \mathrm{E}-03$ & $1.38 \mathrm{E}-02$ & $1.23 E-03$ & & & $5.82 \mathrm{E}-03$ & $5.18 \mathrm{E}-04$ \\
\hline 75 & NITRATE & $M$ & & & $1.12 \mathrm{E}-01$ & & & & $1.52 \mathrm{E}-03$ & & & \\
\hline 76 & PHENANTHRENE & M & & & $1.48 \mathrm{E}-03$ & & & & $3.75 \mathrm{E}-04$ & & & \\
\hline 77 & POTASSIUM & Bkg,M,EPA-10 & & & & & & & & & & \\
\hline 78 & PYAENE & $M$ & & & $4.40 E-03$ & & & & $3.00 E-04$ & & & \\
\hline 79 & SELENIUM & $M$ & & & $5.95 \mathrm{E}-03$ & & $8.40 E-03$ & & $1.68 \mathrm{E}-03$ & & & \\
\hline 80 & SILVER & $B \mathrm{~kg}, \mathrm{M}$ & & & & & & & & & & . \\
\hline 81 & SILVER CHLORIOE & $M$ & & & $1.79 E+00$ & & & & & & & \\
\hline 82 & SODIUM & Bkg,M,EPA-10 & & & & & & & & & & \\
\hline 83 & STRONTIUM & $M$ & & & $2.66 \mathrm{E}-04$ & & & & & & $3.35 \mathrm{E}-06$ & \\
\hline 84 & STRONTIUM CHLORIDE & $M$ & & & $3.98 \mathrm{E}-09$ & & & & & & $5.00 \mathrm{E}-11$ & \\
\hline 85 & SULFATE (SULFUR) & $M$ & & & 5.50E-05 & & & & & & $1.64 \mathrm{E}-05$ & \\
\hline 86 & TITANIUM (a) & Bkg, M & & & & & & & & & & \\
\hline 87 & TOLUENE & $M$ & & & 2.12E-03 & & & & $5.83 \mathrm{E}-03$ & & & \\
\hline 88 & TOTAL PETROLEUM HYDRO & NS & & & & & & & & & & \\
\hline 89 & VANADIUM & $B \mathrm{~kg}, \mathrm{M}$ & & & & & & & & . & & \\
\hline 90 & XYLENE & $M$ & & & $5.67 \mathrm{E}-02$ & & & & & & 4.50E-03 & \\
\hline 91 & ZINC & $M$ & & & $1.01 \mathrm{E}-01$ & $1.30 E-01$ & $2.81 E-02$ & $3.61 \mathrm{E}-02$ & $7.19 E-01$ & $9.23 E-01$ & & \\
\hline 92 & ZIRCONIUM (a) & Bkg,M & & & & & & & & & & \\
\hline & & & & & & & & & & & & \\
\hline \multirow[t]{2}{*}{ (a) } & Concentrations of these chen & all within & & & & & . & & & & & \\
\hline & their respectively occurring $b$ & und levels. & & & & & & & & & & \\
\hline
\end{tabular}


Table C.3. Results for Groundwater Away from the Columbia River

\begin{tabular}{|c|c|c|c|c|c|c|}
\hline & & Carcinogenic & Hazard & WOC & LC50/100 & TLM \\
\hline & & Risk & Index & Screen & Screen & Screen \\
\hline Name of Anaiyte & Notes & Ranking & Ranking & Ranking & Ranking & Ranking \\
\hline \multicolumn{7}{|l|}{100 Areas } \\
\hline Chromium $(+6)$ & 1 & 5.31E-02 & $1.30 \mathrm{E}-03$ & $1.43 \mathrm{E}-01$ & 1.57E-01 & \\
\hline Nitrate & $M$ & & $4.77 E+01$ & & $6.50 E-01$ & \\
\hline Strontium-90 & & $3.62 \mathrm{E}-07$ & & & & \\
\hline Tritium (Hydrogen-3) & & $5.16 \mathrm{E}-09$ & & & & \\
\hline & & & & & & \\
\hline \multicolumn{7}{|l|}{200 West Area } \\
\hline Arsenic & 1 & $1.82 \mathrm{E}-05$ & $3.47 E-02$ & $1.26 \mathrm{E}-04$ & $2.18 \mathrm{E}-03$ & \\
\hline Carbon Tetrachloride & $M$ & 5.37E-04 & $5.90 \mathrm{E}+00$ & & $5.25 \mathrm{E}-03$ & \\
\hline Chloroform & 1 & $4.16 \mathrm{E}-06$ & $6.93 \mathrm{E}-02$ & & $1.60 \mathrm{E}-03$ & \\
\hline Chromium & 1 & $1.09 \mathrm{E}-02$ & $2.67 \mathrm{E}-04$ & $2.94 \mathrm{E}-02$ & $3.23 \mathrm{E}-02$ & \\
\hline Fluoride & $M$ & & $1.38 \mathrm{E}-02$ & & & $4.38 E-03$ \\
\hline lodine-129 & & 2.71E-08 & & & & \\
\hline Nitrate & $M$ & & $4.85 E+02$ & & $6.61 E+00$ & $:$ \\
\hline Technetium-99 & & 9.13E-08 & & & & \\
\hline Trichloroethylene & $M$ & $3.02 E-08$ & & & 5.82E-05 & \\
\hline Tritium (Hydrogen-3) & & $4.00 E-07$ & & & & \\
\hline Uranium & & $1.61 \mathrm{E}-07$ & & & & \\
\hline \multicolumn{7}{|l|}{200 East Area } \\
\hline Arsenic & 1 & 1.82E-05 & 3.47E-02 & $1.26 \mathrm{E}-04$ & $2.18 \mathrm{E}-03$ & \\
\hline Cesium-137 & & $2.73 E-04$ & & & & \\
\hline Chloroform & 1 & $1.82 \mathrm{E}-08$ & $3.04 \mathrm{E}-04$ & & $7.00 \mathrm{E}-06$ & \\
\hline Chromium & 1 & $9.75 \mathrm{E}-03$ & $2.38 \mathrm{E}-04$ & $2.62 E-02$ & 2.88E-02 & \\
\hline Cobalt -60 & & $3.79 \mathrm{E}-04$ & & & & \\
\hline Cyanide & $M$ & & $1.95 \mathrm{E}-03$ & $1.72 \mathrm{E}-01$ & & \\
\hline lodine-129 & & $1.81 \mathrm{E}-08$ & & & & \\
\hline Nitrate & $M$ & & $1.46 \mathrm{E}+02$ & & $1.99 E+00$ & \\
\hline \multicolumn{7}{|l|}{ Plutonium-239/240 } \\
\hline Strontium-90 & & 1.04E-06 & & & & \\
\hline Technetium-99 & & $7.61 \mathrm{E}-08$ & & & & \\
\hline Tritium (Hydrogen-3) & & $2.66 \mathrm{E}-07$ & & & & \\
\hline Uranium & & $2.69 \mathrm{E}-09$ & & & & \\
\hline & & & & & & \\
\hline \multicolumn{7}{|c|}{600 Area (Solid Waste Landfill Site) } \\
\hline Chloroform & 1 & $1.30 \mathrm{E}-09$ & 2.17E-05 & & $5.00 \mathrm{E}-07$ & \\
\hline Dichloroethane, 1, 1- & $\mathrm{M}$ & & $4.92 \mathrm{E}-06$ & & $3.18 \mathrm{E}-06$ & \\
\hline Tetrachloroethene & $M$ & $2.66 \mathrm{E}-07$ & $5.21 E-04$ & & $9.23 E-05$ & \\
\hline Trichloroethane, $1,1,1$ - & $\bar{M}$ & $5.60 \mathrm{E}-07$ & $2.44 \mathrm{E}-03$ & & $1.00 E-04$ & \\
\hline Trichloroethene & $M$ & $1.90 \mathrm{E}-08$ & & & $1.27 E-05$ & \\
\hline
\end{tabular}




\section{Distribution}

No. of

Copies

Offsite

12 DOE Office of Scientific and

Technical Information

M. Bauer

Confederated Tribes and Bands of the

Yakama Indian Nations

P.O. Box 151

Toppenish, WA 98948

S. Benz

600 S. Kent $\# 71$

Kennewick, WA 99336

L. Block

U.S. Fish and Wildlife Service

Moses Lake Field Office

P.O. Box 1157

Moses Lake, WA 98837

D. Bradshaw

Audobon Society of Portland

5151 Northwest Cornell Road

Portland, OR 97210

N. Buske

Search Technical Services

Star Route Box 17

Davenport, WA 99112

D. Cellarius

Sierra Club Northwest Office

1516 Melrose Avenue

Seattle, WA 98122

C. Cline

Washington State Department of Ecology

P.O. Box 47600

Olympia, WA 98504-7600
No. of

Copies

F. R. Cook

2552 Harris

Richland, WA 99352

J. P. Corley

2213 Torbett

Richland, WA 99352

2 DNR Hanford Projects

Attn: J. R. Wilkinson

Confederated Tribes of the Umatilla

Indian Nation

P.O. Box 638

Pendleton, OR 97801

G. deBruler

Columbia River United

P.O. Box 667

Bingen, WA 98605

C. Denniston

Greenpeace

11815 - 20th SW

Seattle, WA 98146

B. Drost

USGS Water Resources Division

Washington District

1201 Pacific Avenue Suite 600

Tacoma, WA 98402

D. Dunning

Oregon Dept. of Energy

625 Marion Street NE

Salem, OR 97310

3 J. Erickson

Division of Radiation Protection

Washington State Dept. of Health

P.O. Box 47827

Olympia, WA $98504-7827$

Distr. 1 
No. of Copies

M. Fox, President

Hanford Family

P.O. Box 1462

Richland, WA 99352

R. Gardiner

614 Sherman Drive

The Dalles, OR 97058

N. J. Germond

League of Women Voters

224 Iron Mountain Boulevard

Lake Oswego, OR 97034

D. Maez

4214 W. John Day Place

Kennewick, WA 99336

C. Mebane

National Oceanic and Atmospheric

Administration

c/o EPA Seattle Office

1200 6th Avenue, HW-113

Seattle, WA 98101

J. Monteith

Oregon Natural Resources Council

1161 Lincoln Street

Eugene, OR 97401

D. Nichols

WNP-1

Building 52

Richland, WA 99352

R. Patt

Water Resources Department

158 - 12th Street N.E.

Salem, OR 97310-0210

G. Pollet

Heart of America Northwest

1305 4th Avenue, 208

Seattle, WA 98101
No. of

Copies

2 D. Powaukee

Nez Perce Tribe

P.O. Box 365

Lapwai, ID 83540

L. Stembridge

HEAL

1408 West Broadway Avenue

Spokane, WA 99201-1902

C. Stephan

1520 Torthay Court

Richland, WA 99352

3 D. Stewart-Smith

Oregon Department of Energy

625 Marion Street NE

Salem, OR 97310

J. P. Thomas

HHIN Resource Center

1719 Smith Tower

506 Second Avenue

Seattle, WA 98104

Onsite

11 DOE Richland Operations Office

R. F. Brich (5)

H4-83

P. W. Willison

A4-52

DOE Public Reading Room (5)

$\mathrm{H} 2-53$

6 Washington State Department of Ecology

S. M. Alexander

B5-18

D. P. Holland (4)

B5-18

J. W. Yokel

B5-18

4 Westinghouse Hanford Company

Administrative Record (3) H6-08

A. S. Carlson

B3-35

Distr. 2 
No. of

Copies

6 U. S. Environmental Protection Agency

L. E. Gadbois (5)

D. R. Sherwood

34 Pacific Northwest Laboratory

S. D. Cannon

R. L. Dirkes

P. W. Eslinger

S. L. Friant

M. S. Hanson

G. L. Harvey

P. C. Hays
B5-01

B5-01

K9-13

K6-61

K9-13

K6-52

K9-02

$\mathrm{K} 2-02$

K9-41
No. of

Copies
L. R. Huesties K6-61

A. D. Maughan K6-52

T. B. Miley

L. F. Morasch

B. A. Napier (5)

D. B. Shipler

S. F. Snyder

W. L. Templeton

W. H. Walters

L. K. Wenrich (5)

B. K. Wise

Records Center (2)

Publishing Coordination

Technical Library (5)
K5-12

K6-62

K3-54

K9-13

K3-54

K9-13

K9-33

K3-70

K9-04

K3-70

K1-06

P8-55 